\title{
放射線センシングの発展と将来展望 ベクレルによる放射線発見から100年
}

\author{
Past, Present and Future of Radiation Measurements \\ Centenary Review of Discovery of Radio-Activity by Becquerel
}

（1996年 7月29日 受理）

\begin{abstract}
本年(1996年)はべクレルがウランから放出される放射線を写真乾板で発見してからちょうど100年目に当たる。この 100年の間に, 放射線測定器の研究汃日進月歩続けられ, 写真乾板以外の放射線検出器およびそれに伴う電子回路, 信号 処理技術等が開発されてきた。本「特集」ではこの100年間を代表する検出器として，ガス検出器，シンチレーション検 出器およひ半導体検出器についての最新の成果まで含めて解説するとともに, 21 世紀の検出器として現在, 精力的に研 究がなされている超伝㝵梌出器,ファイバ梌出器, イメージングプレート等の研究状況およびそれに伴う信号処理技術の 研究状況などについて, 専門家の方々に解説していただく。

（担当編集委員・片桐政樹）
I 、放射線センシングの発展と䓪
V. 放射線センシングと先端技術の融合
II. 放射線をイメージングする
VI. 放射線センシングに高速ディジタル処理技術を生かす
III. 新しい素材に上る放射線センシング
VII. 放射線センシングと高度計算処理
IV. 次世代の放射線スペクトロスコピー
VIII. おわりに

\section{I. 放射線センシングの発展と夢}

\section{1.「ゼロ・エミッション」の時代へ}

「この100年間の科学技術の発展は, まさに人類史上でも まれな，革命的なるのでありました。また，日本では戦後 50年の驚くべき経斉的発展は，日本人の勤勉さとともに, 多くの技術開発が，それを推進してきました。これから あ,この科学技術の基盤を強化し，大いに展開していく必 要があります。」

とはいえ，このような楽天主義や脳天気な科学技術万能 主義ばかりでは，済まされない時代に入りつつあることも 確かである。次代を担う若者達の理科離れ，物理嫌いを始 め,「ゼロ・エミッション」社会への転換など，時代が変化 し，価值観の混沌とした状況にいる上うな気がする。

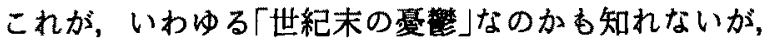
100年前にす，科学の世界は，同じような閉塞状態にあっ たらしいと読んだことがある。科学知識は，一種の飽和状 態にあったようである。そのような状況から，突然出てき たのが X線であり, ウランの放射能であったわけである。

\section{2. 時代を反映する技術のセンシング}

放射線という言葉も20世紀の科学技術のキーワードの 1
東京大学 中 沢 正 治

つである。新しい原子核の世界とのコミュニケーションの 道具として，その世界の仕組を人間に教えるとともに， そ の世界加らェネギーを取り出すために使用されている。

放射線センシングは，そのコミュニケーションのための 道具であり，人間の目や耳,触角の機能を果たしているす のである。始めは，写真フィルムやガイガー計数管が使わ れ, やがて, 光電子增倍管という素晴らしい光センサーの 開発により, $\mathrm{NaI}(\mathrm{Tl})$ シンチレータの時代になり, 現在, 半導体の時代に入っている。

放射線センシングは，この100年間，各時代の技術の枠 を集めて作られてきた。この20世紀は，放射線計测屋に とって, 誠に幸福な時代であった。光電子增倍管, 半導体, コンピュータなどの新材料, 新技術をセンシングに利用し てきた。現在は, 光ファイバ, レーザー, 超伝導材, 微細加 工, 原子間力顕微鏡などが利用され始めていることは，以 下に詳述されている通りである。

\section{21世紀への夢と希望}

放射線センシングは，その時代の技術レベルやトレンド を反映するセンサーでああるわけである。本「特集」では， 個別技術の展開を通して, 新しい21世紀のセンサーの1 
メージを想像してみることすできる。

筆者の印象では，これらの放射線センシング技術の目指 している方向は，まず第 1 段階は，放射線用のホームビデ オカメラのようである。より色鮮やかに(高エネルギー分 解能で)より高感度に，手軽にどこです実時間で放射線イ メージを撮ろうというすのである。

したがって，次の段階では当然，人間の眼のような知能 を持ったセンサーの開発の方向である。ミクロ量子の世界 を自由に見られるようになると，ミク口の世界の様子がよ くわかり，量子の世界を操作したくなる。操作の道具むや
はり，放射線，量子ビームということになる。分子ビーム

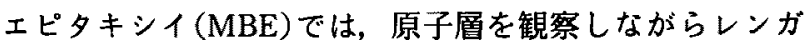
のように 1 層ずつ組み上げていく点で，そのような方向の 萌芽的装置とむいえる。

放射線をミクロの世界とのコミュニケーションの道具と して自由に使用できる時代，そのような新しい世界の開拓 がどれほど進んでいるのかを，この100年記念の本「特集」 から感じて頂くこと，そして，その技術を「ゼロ・エミッ ション」の時代にどのように活用すべきかを考えて頂くこ とが，本「特集」の目的ではないかと考えている。

\section{II. 放射線をイメージングする}

名古屋大学 森 千鶴夫, 日本原子力研究所 新村 信雄,

東京工業大学 谷森 達, 越智 敦彦, 西 勇二, (楸日立製作所 出海 滋, 放射線医学総合研究所 山本 幹男

\section{1. 蛍光板·X 線フィルムからイメージング プレートへ}

警くべき性能を有するイメージングプレート(IP)システ ムが純国産の技術であることを吾がことのように何か誇ら しく感じるとともに、こんな技術開発がまだ残っていたの かと思うほどである。科学技術はいつの時代になっても， まだまだ革新的な進展があり得ることを身近に感じさせる 好例であろう。

IP システムは約15年前, 富士写真フィルムが実用化し た放射線强度 2 次元分布測定システム(1)(2)である。もと ちと医療用の X 線写真フィルムに代わる新しいフィルム の提供を目的として開発されてきたものである。現在，生 物分野におけるオートラジオグラフィーに多用され，医療 用では，病院によってはほとんど100\% IPに置き替わって いるところもある。まさに小題目のように「蛍光板・X 線 フィルムからイメージングプレートへ」の表現が可能であ る。医療用・生物学用のみではなく，最近では，ょり一般 的な放射線，放射能，原子力の分野で用いられつつある。

IPの特徵をX 線フィルムと比較して，次のように要約 することができる。

（1）放射線に対する感度が100倍以上，1,000倍にも達す るほど高い。

(2) 位置分解能は高分解能システム(BAS5000)では 25 $\mu \mathrm{m} \times 25 \mu \mathrm{m}$ であり, ラジオグラフィー的な使用法で はX線フィルムにほぼ同等に近い。

(3) 放射線の入射量に対して線形応答を示す範囲が 3.5 〜 4杕あり,きわめて広い。

(4) レーザービームによって高速読み出し (2，3 分間) を行うので，湿式現像操作は必要ない。

（5）位置の情報と放射線強度の情報をディジタルにメモ リーしているので, コンピュータ操作により特定強度
範囲の强調操作, バックグラウンド的強度の差引操 作, 色表示等が自在である。

（6）医療用 X 線フィルムと同等の広い面積のIP むある。

（7）一度使用したIPの潜像を消去して，1,000回程度以 上の絽り返し测定が可能である。欠点は潜像を読み出 す前に潜像が退行することである。しかしこれも使い

方によってはあまり問題ではない場合がある。

IP とそのシステムについて少し詳しく述べる。IPは厚 さ約 $150 \mu \mathrm{m}$ のポリエステルフィルム上に $\mathrm{BaFBr}_{0.85} \mathrm{I}_{0.15}$ : $\mathrm{Eu}^{2+}$ の微結晶 ${ }^{(3)}($ 粒子サイズ約 $5 \mu \mathrm{m})$ を厚さ $80 \sim 150 \mu \mathrm{m} に$ 塗布し，その表面を厚さ $10 \mu \mathrm{m}$ のポリエチレンテレフタ レート膜で保護している。第 II-1 図に，この結晶のエネ ルギー準位図と放射線潜像の形成および読取りのメカ二ズ ムを示す。放射線が入射し，そのエネルギーが吸収される と価電子帯から伝導電子帯に電子を励起し，放射線の吸収 エネルギーにほぼ比例した数の電子ホール対を作る。電子 はフッ素ないしシュウ素の, いわゆる色中心 $\mathrm{F}^{+}$センター に捕猚されFセンターを作り，ホールは $\mathrm{Eu}^{2+}$ に捕獲され $て \mathrm{Eu}^{3+}$ となる。これが入射放射線の入射場所に対応した

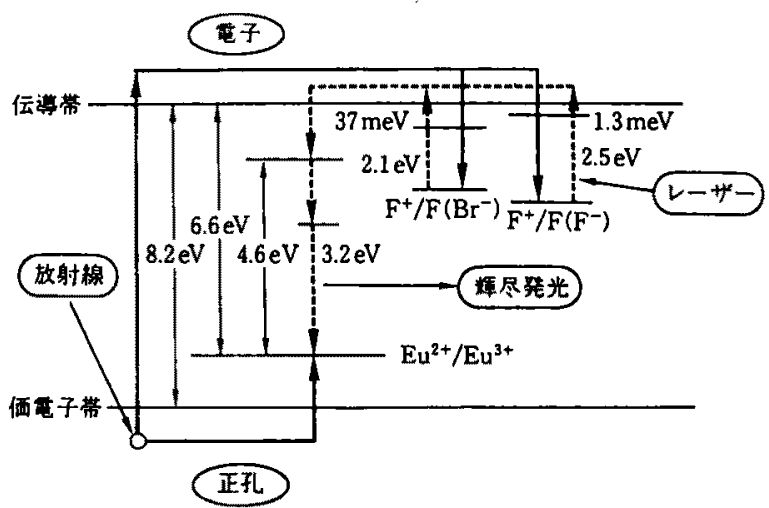

第 II-1 図 輝尽性発光体 BaFBr：(Eu)のエネルギーレベル と潜像形成過程および輝尽発光過程 
潜像が蓄積されている状態である。これに不用意に光を当 てると, 潜像はかなり消失する。

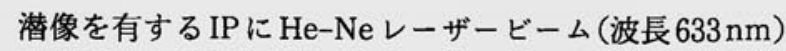
を当てると, $\mathrm{F}$ センターから電子が伝導電子帯に励起さ れ， $3.2 \mathrm{eV}$ すなわち $390 \mathrm{~nm}$ の輝尽性発光が発生する。細 く絞られたレーザービームが走查する位置と輝尽性発光の 強度をディジタル信号に変換してコンピュータにメモリー する。メモリーをCRT 画面上に読み出し，データの加工 等を行って判断したり, プリントアウトできる。カラー表 示が可能なのむ大きな魅力である。

IP の実用分野として, 次の分野がある。(1) X 線写真の 分野において, 医療用では多くの病院で採用されつつあ る。またX 線回折の分野でも前述の特徵のため, 各 X 線 回折装置メーカーが積極的に組み込み, 回折像の撮影にお いてX線フィルムを駆逐しつつある。演算処理の仕方に よっては従来得られなかった新しい結果が得られるので当 然である。シンクロトロン放射光による回折にも実用的に 使用されている。(2)電子顕微鏡の分野でも, 高分解能のシ ステム(FDL5000)が開発されたことにより多用されてい くであろう。(3)中性子回折, 中性子ラジオグラフィー用と して, Gdまたは Li を入れた IP 原研と富士写真フィルム が開発した ${ }^{(4)}$ 。今後, 多用されると思われる。

IPのより多様な応用と問題点について述べる。高感度 性を利用して, 食品, 岩石, 陶磁器に含まれるきわめて低レ ベルの自然放射能の分布を測定することができる(第 III-2 図 $\left.{ }^{(5)}\right)$ 。ただしこの場合に周辺からの自然放射線の強度を 遮蔽によって1栴以上少なくする必要がある。この場合, 遮蔽箱の内面加電子をできる限り発生させないようにす る必要があり, 通常の Ge 検出器などに対する遮蔽とは目 的, 方法がやや異なる。

極微量の污染検查などに対してはきわめて有効で，ほと

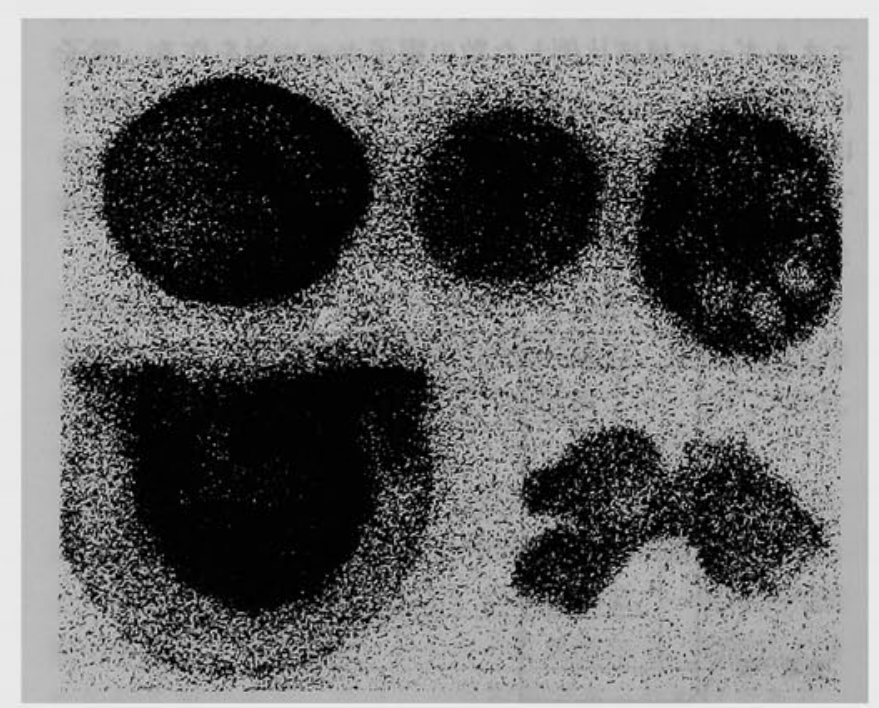

第 II -2 园 野菜の中に含まれる自然放射能分布像 左上加ら右へ $\left({ }^{40} \mathrm{~K} \beta\right.$ 線による像) ジュガイモ,サッマイモ,レンコン, カボチャ,ショウガ
んどこの方法でなければ検出できない量の検査も可能であ る。ただしこの場合, 放射線の種類やエネルギーによって 感度が異なることと, 潜像の自然退行現象のため, 定量性 にはやや問題がある。

IP の特徵は個人線量計としての有効性を示しているが, 前述の退行現象の存在がブレーキとなっている。

積分型検出器であるIPのアウトプットから入射放射線 の線質やエネルギーの弁別の可能性が検討されてい

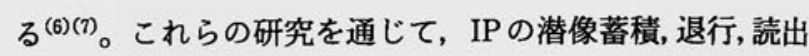
しにおける現象を支配する因子はまだ十分には解明されて いないことが感じられる。なお，最近IPに関する優れた 解説が武部によってなされているる

（森 千鶴夫）

\section{2. 中性子をイメージングする}

中性子は, 電気的に中性な粒子であるため電離作用はな いが, 熱中性子はある核種と核反応をするので，そのとき 生じる 2 次荷電粒子の電離作用を利用して, 中性子を検出 することができる(これら核種を中性子コンバータと呼 ぶ)。例えば ${ }^{10} \mathrm{~B},{ }^{3} \mathrm{He}$ は気体比例計数管, ${ }^{6} \mathrm{Li}$ はンンチレー 夕, $\mathrm{Gd}$ は写真法, そして ${ }^{235} \mathrm{U}$ は核分裂検出器に用いられ ている。中性子をイメージングするため, 古くから用いら れ, 今なお, 中性子ラジオグラフィーで用いられているの が, $\mathrm{Gd}+\mathrm{X}$ 線フィルム法である。 Gdを約 $25 \mu \mathrm{m}$ 蒸着した $\mathrm{A} 1$ 板に X 線用フィルムを密着させ, 中性子捕獲で $\mathrm{Gd}$ から 放出される内部転換電子により, $\mathrm{X}$ 線用フィルムを感光 している。解像度は, 最も分解能の高い X 線フィルムで $50 \mu \mathrm{m}$ である。感度は $25 \mu \mathrm{m}$ 厚の $\mathrm{Gd}$ で中性子は $100 \%$ 捕萑 されるが, 2 次粒子である内部転換電子の, X線フィルム に入射する効率が $1 \%$ 以下となり，中性子検出感度は $1 \%$ 以下となってしまう。最近は中性子入射位置を弁別できる 気体比例計数管やシンチレータを用いたエリアディテク 夕 $^{(9)}$ が多く使われ出しているが, その標準的な性能は, 検出効率 $50 \sim 90 \%$ (中性子波長に依存する), 最大計数率 $10^{4} \sim 10^{6}$ カウント $/ \mathrm{s}$, 位置分解能 $2 \sim 5 \mathrm{~mm}$ が原理的な限 界であった。そのため 1 桁以上の性能向上には新しい夕イ プの検出器の開発を待たざるを得なかった。

最近, 中性子イメージングプレートが開発された ${ }^{(10)}$ が, それの熱中性子検出器としての性能を総合的に検討する と, 中性子検出器として未だかって経験したことのない僈 れたものであり, 中性子計測に関連する分野に革命的な効 果を及ぼすことが考えられ，すでにいくつかの応用が報告 されている(11)(12)。

中性子イメージングプレートは, 輝尽性蛍光 (PSL : Photostimulated luminescence) 体に中性子コンバー夕 を均一に混入させた積分型エリア中性子検出器である。中 性子コンパータとしては, Gdないしは ${ }^{6} \mathrm{Li}$ が用いられてい る。中性子がコンバー夕に捕獲されると, 2 次荷電粒子が 放出される。PSL体として, $\mathrm{BaF}(\mathrm{Br}, \mathrm{I}): \mathrm{Eu}^{2+}$ が用いら れているが,この 2 次荷電粒子が, PSL体中にカラーセ 
ンターを生成する。このカラーセンターは準安定で, $\mathrm{He}-\mathrm{Ne}$ レーザー赤色光(波長 $633 \mathrm{~nm}$ ) の照射で紫色発光(波 長 $390 \mathrm{~nm}$ ) し初期安定状態に戻る。この紫色光を光電子增 倍管で検出する。その光量が入射中性子数に比例するの で, 中性子検出器として使える。構造は, 支持層としての $\operatorname{PET(ポリエチレンテレフタレート；180~300\mu m)のシー~}$

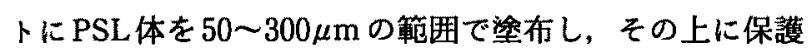
層(3 10 $\mu \mathrm{m})$ をおいた，全体でも $1 \mathrm{~mm}$ 厚以下の柔軟な取 扱い容易なフィルムである。

中性子イメージングプレートへの入射中性子数と，それ により発光するPSL 量との直線関係が保たれる範囲を多 イナミックレンジと呼ぶ。実測によると，Gdコンバー夕 では 5 桁，Li コンバータでは 4 桁のダイナミックレンジ を確認できた。中性子イメージングブレートの位置分解能 は $200 \mu \mathrm{m}$ 以下で，実験条件，䛃取条件をうまく選べば 50 $\mu \mathrm{m}$ 程度まで可能である。中性子検出効率は用いる中性子 波長によるが，50〜80\%という值が得られている。

コンバータの種類と組成比,イメージングブレートの厚 みを変化させる実験から中性子イメージングプレートの最 適条件が検討されている(13)。コンバータからの 2 次荷電 粒子は，それのエネルギーの総和を $E s p, 1$ 個のカラーセ ンターをPSL体に生成するのに必要なエネルギーを光と すると，(Esp/的) 個のカラーセンターを生成する能力を 有する。2 次荷電粒子およびそれからの電離電子の飛程で PSL体中に形成される体積中にある PSL 体の個数を $N_{\mathrm{psl}}$ とすると, $\left(E s p / \omega_{0}\right)$ と $N_{\mathrm{psl}}$ の大小関係で, カラーセン ターの生成表式が異なる。第 II-3 図に, PSL体のモル比 $\phi_{\mathrm{gsl}}$ の関数としてのカラーセンターの生成数を示す。つま り，カラーセンターの生成数は PSL 体のモル比の增加と ともに直線的に増加し，ある臨界值以上では一定値Esp/ $\omega_{0}$ となる。

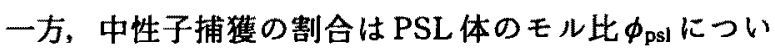
て, 減少関数(コンバータ原子数については增加関数)であ るので, 中性子入射数と発光PSL 量は $\phi_{\mathrm{ps} 1}$ のある一定值に

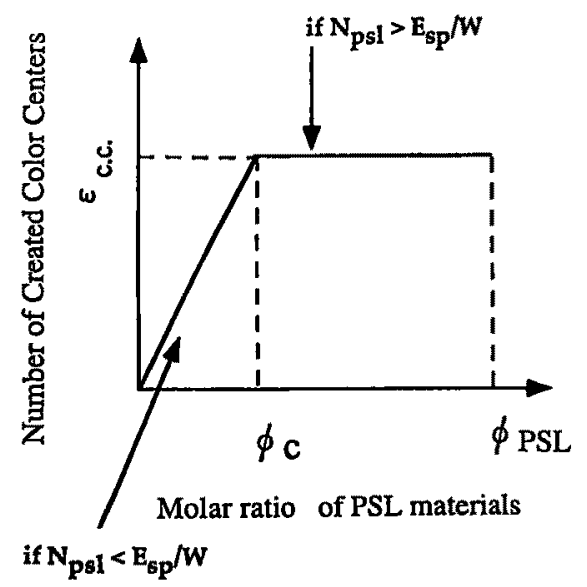

第 II-3 图 中性子イメージンクフプレートに生成されるカ ラーセンタ量のPSL体組成図(モル比)依存性
最大值がある。Gd コンバー夕、 ${ }^{6} \mathrm{Li} コ$ コバータにつき $\phi_{\mathrm{vsl}}$ および厚みを変化させ, 中性子入射数およびそれによる発 光PSL 量を実测し, 最適値が求められており, 最適PSL 体組成比は，それぞれ60\%，15\%，厚みは両方共 $200 \mu \mathrm{m}$ である。

中性子をイメージングする最す典型的な実証例は中性子 シジオグラフィーである。日本原子力研究所JRR-3Mに 設置されている中性子ラジオグラフィ一装置で，中性子イ メージングプレートを用いて種々の害験を行い, 良好な結 果が得られている(10) (12)。

蛋白質やDNA の 3 次元立体構造の中で, X 線回折法で は決定が困難な水素原子の位置を決める中性子構造生物学 では，中性子イメージングプレートが非常に有用である。 著者らはラウエ・ランジュバン研究所(フランス)のラウエ カメラ(LADI)で, 中性子イメージングプレートを用い, 正方晶系ニワトリ卵白リゾチーム単結晶の中性子回折実験 を行ったところ，種々の方位角に結晶を固定させ，約10日 間で独立な反射の数，約 8,000 個を収集することができ た。中性子構造生物学にとって, 中性子イメージングプ レートの出現は革命という言葉に值するだろう。従来の中 性子検出器を用いて, 正方晶系ニワトリ卵白リゾチームの 結晶構造解析用データ収集には, 約 $4 \sim 6$ 力月のマシンタ イムが必要である。1 年分のマシンタイムを蛋白質中性子 結晶学に全部割り当て，すべてが順調にいっても，1〜2 個の試料のデータ収集が限度である。ところが，中性子1 メージングプレートの出現で, 1 年に10 20種類の試料の 実験が可能ということは，構造生物学の研究者の多くの方 に，生体物質中性子回折実験を行う機会が与えられるとい うことである。

中性子イメージングプレートは, 熱中性子 2 次元エリア 検出器であり，原理的には，現在一般に使われているガス 封入型比例計数管にとって代われるるのである。例えば， 熱中性子回折·散乱実験への応用や，粉末中性子回折，中性 子小角散乱, 中性子反射率計等への応用の試みが開始され ている。

中性子イメージングプレートは, 積分型でかつ位置分解 能がよいので，ダイレクトビームの高速中性子プロファイ ル測定に適している。具体的にはダイレクトビームの一様 性, 試料が適正位置にセットされているかなどの評洒等, すでに実用に供している。

中性子イメージングプレートは1枚のフィルムであるた め, 電気ノイズが生ずることは全くないので, この方面へ の応用も期待される。この意味で, 環境放射線の測定や放 射線遮蔽の漏沂テストにも, 独特な形態で応用の可能性を 有する検出器である。

(新村信雄)

\section{3. 精密な入射位置検出-MicroStrip Gas検出器}

MicroStrip Gas Chamber(MSGC)といっても，まだ多 くの尃門家にもほとんどピンとこないほど, MSGCは生 
まれたての新しい検出器である。しかし，数年以内に完全 なリアルタイム高位置分解能 X 線画像装置として実用化 されつつある。MSGC は原理的には全く多線比例計数管 (MWPC)であり, 新しいものではない。ただ, MWPCを IC 微細加工技術を用い，第 II -4 図に示すように，基板 (substrate) 上に数 $10 \mu \mathrm{m}$ 幅のアノード，カソード電極を 形成して作るワイヤレス型ガス比例計数管と同じであり, 1988年，フランスのOedによって考察された ${ }^{(14) 。}$

MSGC の特徵はまず $200 \mu \mathrm{m}$ 程度という電極間隔の狭さ である。これにより，簡単に MWPC の 5 倍以上の $50 \mu \mathrm{m}$ の位置分解能と 100 倍以上の高計数率が可能になる。さら にはIC技術により性能の揃った検出器が回路のように量 産が可能になり，ほとんど手作業で性能も不揃いであった MWPC とは大きく異なる。このような画期的な特徽を備 えているために, 高エネルギー物理学や大強度放射光での 次期位置検出器として各国で開発が進められている。

東工大グループは1991年から独自にBare LSI Chipを実 装する Multi-Chip-Module(MCM)技術を用いて MSGC を開発している(15)。この MSGC の特徴は第 I-4 図にある ように基板に厚さ〜 $20 \mu \mathrm{m}$ のポリイミド薄膜を用いて 2 薄 膜の下層にある Back Strip に誘起される信号を使って 2 次元読出しを可能にしている。一方, 現在他の多くの MSGC は厚さ数 $100 \mu \mathrm{m}$ のガラスを基板に用いた, 次期高 エネルギー陽子・陽子衝突実験 LHCの飛程検出器としての 1 次元MSGC の開発が中心となっている(16)。

このように MWPCに比べて非常に優れた特性を持って いるが, MWPCを一度扱った人ならすぐに気付くように, アノード近傍で起こる増幅作用で作られる正イオンが電極 が形成している基板上に付着し，その空間電荷効果でゲイ ンの低下を引き起こしてしまう。そのため, 現在, 基板の 材質として, 各種の誘電体の選択, さらにイオン注入法な どによって最適な抵抗值を見い出す研究が盛んに行われて いる。ちなみに著者らはポリイミドの表面に有機チタニウ

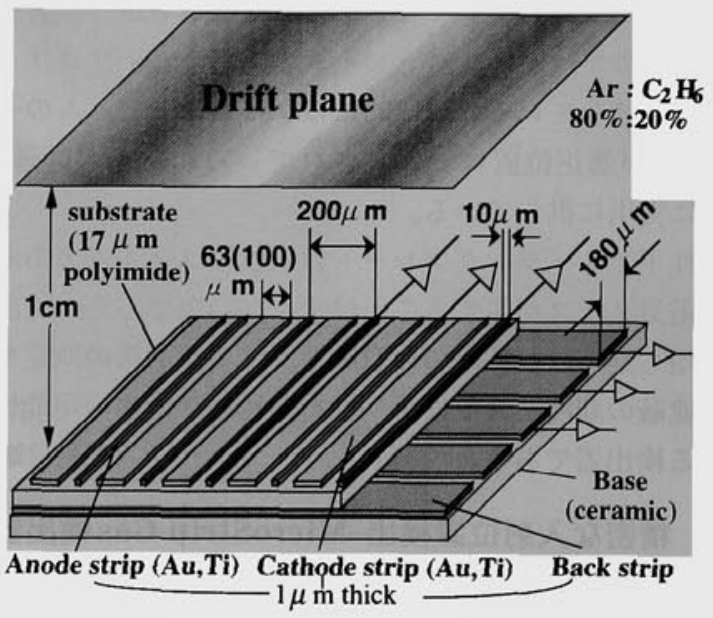

第 II-4 図 MSGCの構造

\section{集}

ムをコーティングし，表面抵抗をコントロールしている。 その他, 電極間の放電対策など多くの開発が行われている が，詳しくは文献を参照されたい(15)(16)。

次に MSGC はどのような分野での応用が期待できるか を述へていきたい。上記にあるように, 高位置分解能およ び圧倒的な高計数率能力から，大強度 $\mathrm{X}$ 線ビーム用の画 像検出器としての応用が最も期待されている。MSGC は 現在使用されているフィルム, イメージングプレート，X 線カメラなどの積分型検出器とは異なり, 各X線の入射 時間およびエネルギー情報を完全に記録することができる 微分型検出器であり, 完全なディジタルデータを供給する リアルタイム型検出器である。さらにMSGC はMWPC と 異なり, 任意の形状で電極を形成でき, ポリイミドのよう なフレキシブルな素材を使用することにより曲面型の形状 あ可能であり, まさしく画像検出器として最適である。

第 II -5 図に示すのは著者らが開発した $5 \mathrm{~cm}$ 角 MSGC を, ICパッヶージにマウントしたものである。このパッ ケージをアンプ基板上に取り付ければよく, 全く回路の 1 部品と考えることができる。特に新たな試験をするとき は, この MSGCパッヶージを付けかえるだけですみ, 面 倒な配線のやり直しなどは一切必要なく, 開発の効率を飛 躍的に向上することができた。このMSGCから得られた プリント基板の透視 X 線画像を第 II -6 図に示す。 $300 \mu \mathrm{m}$ 径のピンホール列がはっきり掘えられ，さらに基板上のパ ターンあきれいに出ている。MSGCのイメージはディジ タルであるために無限に広いダイナミックレンジを持って おり，またその中から，わずかな密度変化す捉えることが できることをこの図は示している。現在，Arガスを使用 しているため, 光電効果で放出される光電子の散乱による ボケが位置分解能を決めてしまっているが, Xeガスを使 用すれば $50 \mu \mathrm{m}$ 程度の分解能が得られる。しかし，これは 光電子の散乱方向が測れることを意味しており, MSGC で X線偏極が測定できることを示している。現在, $8 \mathrm{keV}$ 偏光 $X$ 線に対して $20 \%$ 以上のモジュレーション值を得て おり, さらに改良を進めている。これは多分, 初めての画

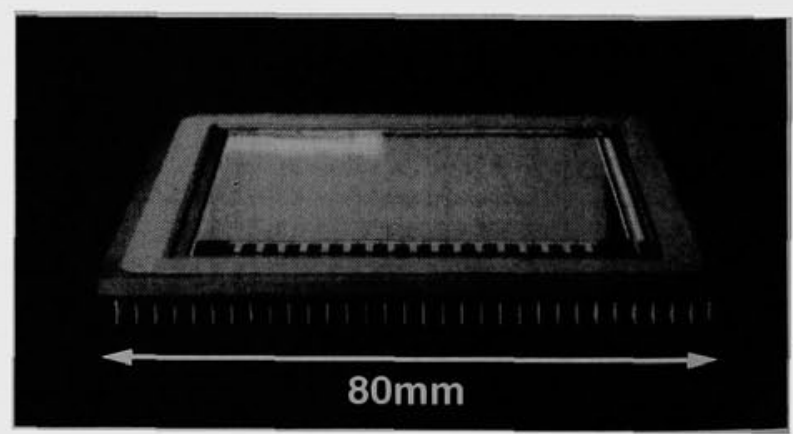

第 II-5 図 Pin Grid Array(PGA)パッケージにマウントさ れた $5 \mathrm{~cm}$ 角 MSGC

このバッケージの噈面に約 500 本のビンがあ り, MSGCからの信号を基板上のアンプに送る。 


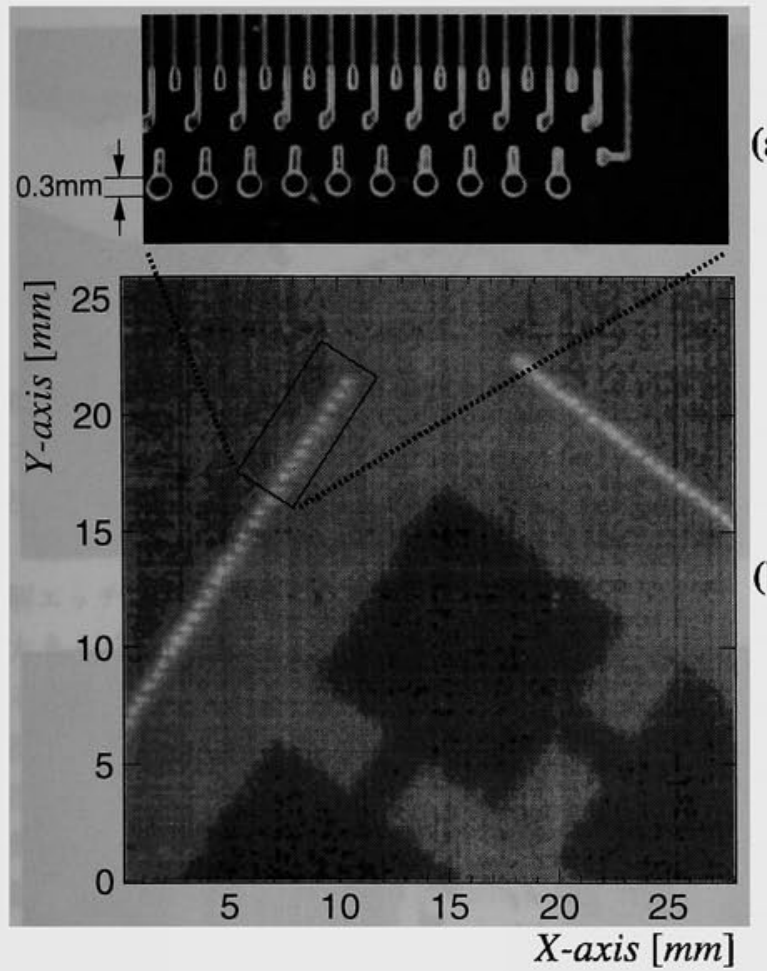

第 II-6 図 MSGCによって得られた高密度ブリント基板の 透視図

このプリント基板(a) は $10 \mathrm{~cm}$ 角 MSGC を直接 ボンディングで取り付けるために開発されたも のであり, ボンディング用の $300 \mu \mathrm{m}$ 径のスルー ホールの列と基板上のアースのパターンがはっ きり見える(b)。

像 X線偏光検出器ではないかと思っている。これにより， 今まで, 全く不可能であった宇宙の磁場構造を知るための 宇宙X線偏光の分布などが測定可能となる。

著者らの MSGC は高計数率を実現するために, 各信号 線に高速アンブおよびディスクリミネータを付けパルス化 しディジタル処理で座標に変換する方式をとっている。 現在，数 $10 \mathrm{MHz}$ のデー夕処理能力を持った処理回路を製 作しており，この回路と MSGCを組み合わせることによ り毎秒 100 フレーム程度のリアルタイム画像がとれる予定 である。例えば, $10 \mathrm{~cm}$ 角 MSGCでは約 1,000 チャンネル のアンプ,ディスクリミネータ等が必要となる。そのため, スペース,電力, 価格すべての面からIC化されたすのが不 可欠になっている。現在使用しているICアンプ等は市販 の集積度の低いものを使用しているが, $10 \mathrm{~cm}$ 角 MSGC全 体の大きさを $40 \mathrm{~cm}^{3}$ 程度にできる。現在, より小型のア ンプの使用を検討しており, 数年のうちには $10 \mathrm{~cm}$ 程度の 厚さのあのが可能と考えている。このように MSGC は LSI技術による超小型アンブおよび信号処理回路の製作が 可能になって初めて検出器として意味を持つものであり, まさしく90年代の検出器といえよう。

著者らはまず，MSGC を結晶解析のためX X線回折像お よび散乱像をリアルタイムで測定する装置を実現しようと
している。とくにSPring $8^{(17)}$ 用の X 線 2 次元画像検出器 としてまず具体的に開発を進めている。すでに基本動作特 性の測定を終え， $10 \mathrm{~cm}$ 角 2 次元 MSGC を製作している。 最終的には $20 \mathrm{~cm}$ 角の画像検出器を目指している。来年度 のSPring8運転開始時から実用試験を行っていく。

（谷森 達, 越智敦彦, 西 勇二)

\section{4. シリコン半導体検出器を利用した 工業用 X線トモグラフィ}

物体(人体)を切断(破壊)することなく，その内部を観察 したいという願望は昔からあったに違いない。それを実現 したのが X線トモグラフィ(X線 CT)である。X線 CT は, 物体 (人体)の着目する断面内に細いX線ビームを透過し, そのビーム強度の透過による減衰を計測することにより物 体 (人体)の仮想的断面内の密度分布(厳密には X 線の線吸 収係数の分布)を映像化する手法である。X 線 CT はここ 20年の間に長足の進歩を遂げ，医療用としてはすでに成熟 技術になりつつある。これはひとえに，傷つけることなく 人体内部を可視化して詳細な観察ができ，医療における診 断技術として極めて有効な手段であるからにほかならな い。

一方，工業分野においても，X線 CT 非破壊検查技術 として利用できれば, 従来の X 線ラジオグラフィーとは 比較にならないほど物体内部の観察が容易で正確な情報が 把握できる。しかしX線 CT は，医療用ほどには工業分野 ではまだ普及してはいない。これは医療分野に比較して工 業分野の必要性が低いというよりは, ニーズの多様性にそ の原因がある。X線 CTで撮影したい対象は，鉛筆の芯の ように小さいあのからビルや貨物船のような大きな物まで あるに違いない。対象の大きさが多様なだけではなく，そ の材質あ多様である。人体はどこをとってもその密度は 1 $\mathrm{g} / \mathrm{cm}^{3}$ の近辺であるのに対して, 工業製品の撮影対象は気 体のように密度の低い物から鉄や銅のような高密度の物ま でさまざまである。さらに，数 $\mu \mathrm{m}$ の高い分解能が必要な 撮影対象もあれば, 数 $\mathrm{cm}$ の分解能で我慢できるものもあ る。X線 CTは一つの装置でこれらの多様なニーズに応え ることはできない。密度が低く，小さな被検体を対象にす る場合と, 密度が高く, 大きな被検体を対象にする場合で は， X線 CT の設計思想は大きく異なる。前者の場合は X 線の透過力は弱くてあよいので，エネルギーの低いX線 を使う。この場合は医療用の X線 CT の技術がそのまま応 用できる場合が多い。

技術的に問題となるのは後者の場合である。医療用 CT に使う X 線の鉄に対する透過力は弱く, $1 \mathrm{~cm}$ の厚さがあ ると $1 / 1,000$ 程度に減衰するので, 1 ないし $2 \mathrm{~cm}$ を越える 厚さの鉄製の被検体を撮影することはできない。このよう な対象には医療用よりあエネルギーの高いX線を使わな ければならない。電子線線形加速器から得られる数 $\mathrm{MeV}$ 程度の X 線は透過力が強く, $10 \mathrm{~cm}$ の厚さの鉄であ $1 / 10$ 
程度の減衰ですむ。 X 線 CT を工業用に利用する場合に は, (1)鉄換算の被検体の厚さ, (2)空間分解能, (3)撮影時間, の 3 つの性能が十分満足できるものでなければならない。 つまり,どこまで厚い材料が撮影できるか, どこまで細部 か観察できるか，そしてそれらがどれだけ短時間で画像化 できるかが工業用CT の実用化の課題となる。

厚く密度の高い材料を透過したX線は高エネルギーで あっても大きく減衰し, 検出すべき X 線は微弱になる。 高い分解能の CT 画像を得るにはX X 線のビームを細く絞る 必要があり, 細いビームほどX $\mathrm{X}$ 線強度は弱くなる。また 短時間で撮影するには, その微弱な X線強度をなるへくく 短時間に計測し, しかも多数の検出器を並べて同時に多数 のデータを採取しなければならない。したがって検出器は なるへくく型にして実装密度を高くする必要がある。これ ら 3 つの性能のいずれを上げるにも, 高エネルギーのX 線に対する感度の高い小型の検出器を開発し, 微弱な X 線の強度をいかに正確に短時間で測定するかが課題とな る。透過力の強いX線は検出器に対する透過力も強い。 つまり検出器を小型にすると, X線が擦り抜け易いので感 度が低下してしまう。したがって, 工業用の高エネルギー $\mathrm{X}$ 線 CT 実現するための最大の課題は, 透過力の強い高 エネルギーX線を効率よく検出することである。

さて, 原子力の分野では, 施設の内部や周辺の放射線を モニタするために, 従来はGM管などの気体を封入した検 出器かシンチレーション検出器を使っていた。それが最近 では, 常温でも十分に雑音の低いシリコン半導体検出器 (SSD)が使えるようになり, シンチレーション検出器や気 体型検出器からこのSSDに替わりつつある。これは純度 の高いSi単結晶が得られるようになったことと, SSDの 雑音の原因の内部欠陥の発生を防ぐ製造プロセスが確立し たことによる。

この原子力の分野で開発した技術としてのSSDを使う ことによって, 工業用の高エネルギーX線 CT は高い性能 を持っようになった。 $\mathrm{SSD}$ は $\mathrm{Si}$ 基板上の $200 \mu \mathrm{m}$ 程度の厚 さの空乏層が放射線の有感部になる。この薄い空乏層に対 して高エネルギーのX線ビームを垂直に入射したのでは ほとんどの X 線は検出されることなく透過してしまい, 効率は極めて低い。厚さ $0.3 \mathrm{~mm}$ のSSD $4 \mathrm{~mm} \times 50 \mathrm{~mm}$ 程度の短冊形に製作し, その短冊の長手方向にX $\mathrm{X}$ 線ビー ムを入射することによって極めて効率よくX線を検出で き, しかも $0.5 \mathrm{~mm}$ 程度のピッチで多数の検出器を実装で きる。入射するX線のフォトンが 1 個であ $10^{6}$ 個でも強度 に比例した出力が得られる。現在では 500 個ないし 1,000 個 の SSDを実装し, $12 \mathrm{MeV}$ の電子線線形加速器を $\mathrm{X}$ 線源と して使うことにより，鉄換算厚さ $300 \mathrm{~mm}$ 程度の被検体の $1,000 \times 1,000$ の分解能のCT 像を 10 s 以内で撮影すること も可能である。第 II -7 図(a), (b) は, SSDをX線検出器に使 用した工業用高エネルギーX線 CT 装置で, 自動車用の才 ルタネータを撮影した例である。このように高エネルギー

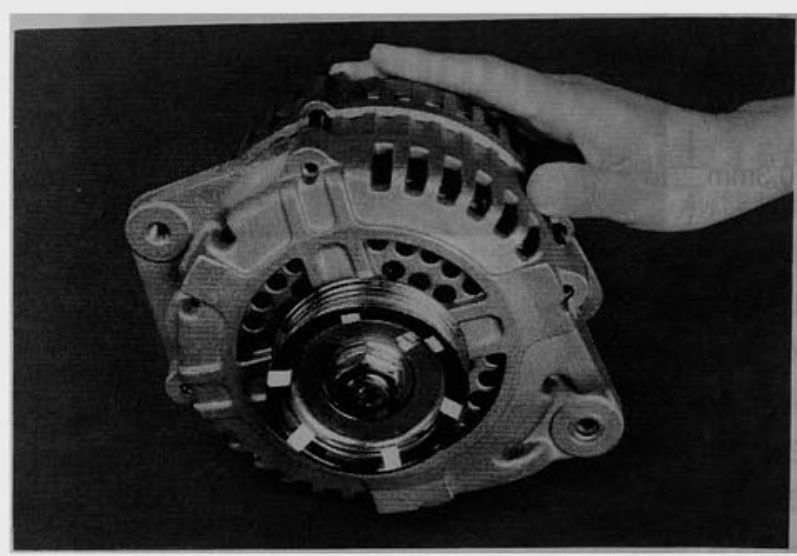

(a) 実物写真(自動車用オルタネータ)

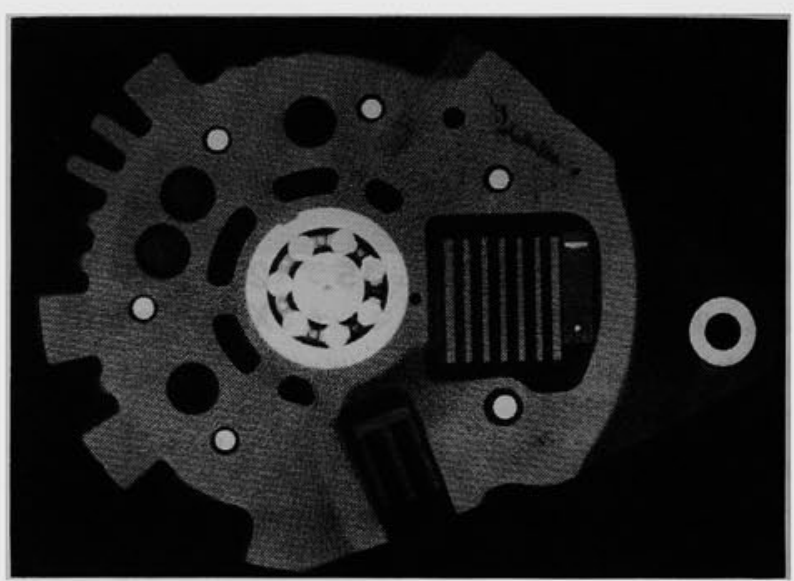

(b) 断層 像

第 II -7 図 シリコン半導体検出器を適用した工業用 X 線 CT 装置による撮影例

$\mathrm{X}$ 線 CT 利用すれば製品内部を精密な画像として観察す ることができる。

新しい製品を開発する過程では必ず試作品を作る。その ような場合に，分解·破壊することなく試作品の内部を詳 細に観察できれば，不具合の原因や改良点が明確に迅速に わかり, 開発を加速することができる。また各種製品の溶 接欠陥や鋳物の内部欠陥，さらには製品内部の寸法計湘も CT撮影により容易に把握することができる。

この観点から, 工業用X線 CT は今後の産業技術の発展 に大いに貢献すると考える。工業用X線 CT は, 原子力分 野で発展した技術が他の産業分野に応用された好例であろ う。

(出海 滋)

\section{5. 原子間力顕微鏡による微細重イオン飛跡 のイメージング}

\section{(1) 背 景}

ガラスやプラスチックなどの板(固体飛跡検出器)に入射 したイオン粒子などが生成した飛跡を検出・解析する方法 を固体核飛跡検出器法と呼ぶ

原子炉材料, 長期打上げの宇宙線固体飛跡検出器, 後記の 
第 II-1表 方法の比較

\begin{tabular}{|c|c|c|c|c|c|}
\hline \multirow[b]{2}{*}{ 観察顕微鏡 } & \multicolumn{2}{|c|}{ 照射密度 } & \multirow{2}{*}{$\begin{array}{c}\text { エッチング } \\
\text { (h) }\end{array}$} & \multicolumn{2}{|c|}{ エッチピット } \\
\hline & $\begin{array}{c}\text { 細胞 }\left(100 \mu \mathrm{m}^{2}\right) \\
\text { 当り }\end{array}$ & $\mathrm{cm}^{2}$ 当り & & $\begin{array}{l}\text { 直 径 } \\
(\mu \mathrm{m})\end{array}$ & $\begin{array}{l}\text { 深さ } \\
(\mu \mathrm{m})\end{array}$ \\
\hline 光 学 & $\sim 0.01$ & $\sim 10^{4}$ & 数〜数 10 & $>5$ & 数〜数 100 \\
\hline （治療に必要） & 約 2 & $2 \times 10^{6}$ & & & \\
\hline 原子間力 & $\sim 100$ & $\sim 10^{8}$ & 0.1 & $<0.5$ & $<0.1$ \\
\hline
\end{tabular}

重粒子線によるがん治療の線量計測や粒子線ラジオグラ フィーなどでは，粒子線照射密度が高くなり，下記の従来 法では困難を来たす(第 II-1 表参照)。

従来の解析法は, 照射後の検出器を長時間化学または電 解エッチングして，エッチピットを直径 $10 \mu \mathrm{m}$ 程度以上に 大きく成長させて, 光学顕微鏡にて観察する方法であ る(19)。ただし,この方法は, (1)エッチピットの深さを直 接実測できないこと，(2) $10^{4} / \mathrm{cm}^{2}$ 以上のイオン粒子照射密 度ではエッチピット相互のくっつきが多くなり, 解析が困 難なこと，などの欠点がある(第 II -1 表参照)。光学顕微 鏡では形状が計測しにくい直径 $1 \mu \mathrm{m}$ 程度の小さなエッチ ピットは, レプリカを作り，それを電子顕微鏡にて観察す る方法ああるが, 手間がかかり精度も不十分である。

原子間力顕微鏡(AFM：Atomic Force Microscope)の 出現により，これらの欠点を乗越える可能性がでてき た (18)(20) (27)。AFMでは, 先の尖った探針で物体表面を 3 次元スキャンする時の, 探針先端と試料間の原子間力を利 用して, nm の精度で物体表面の凹凸を 3 次元実測できる (第 II -8 図参照)。

\section{（2）治療線量計測への応用研究}

著者が本研究を始めた大目的は, AFMを核飛跡解析に 応用すると，どのようなメリットをもたらすかの解明であ

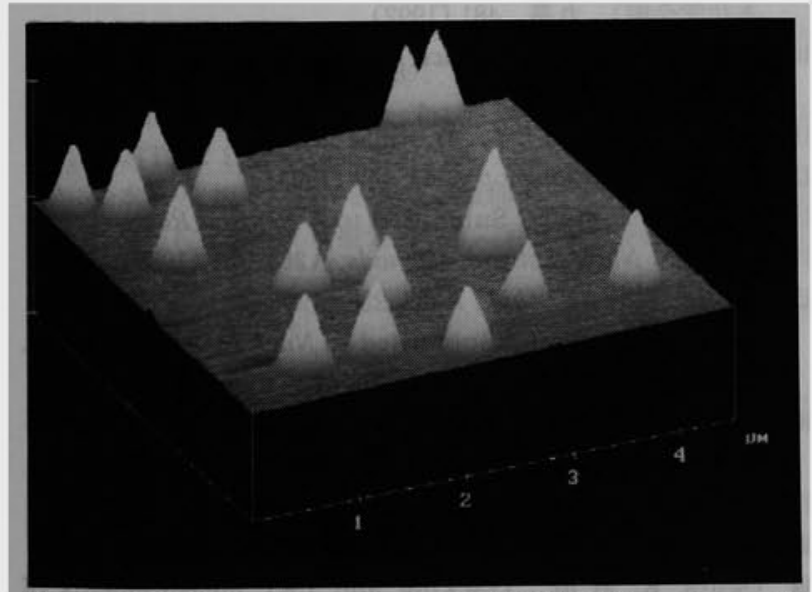

第 II-8 図 微小エッチピットのAFM像(視野約 $4.5 \times 4.5 \mu \mathrm{m}^{2}$ ) 深さ情報の正負逆転表示で, エッチピットの コーン形状が明示されている。高さは位置スケー ルよりる強調表示されている。135 MeV/核子の炭 素イオン粒子にて照射された，後記第 2 組の最後 (\#49)の CR-39 検出器。
る。その一部として, 次の具体的応用例から研究を始め た。

放医研では，重イオン加速器HIMACを開発し，重粒子 線によるがん治療を開始した。その治療を効果的に実行す るためには, 各種の重粒子線照射の作用や効果を, 実際の 治療の線量·照射密度 $\left(10^{6} / \mathrm{cm}^{2}\right.$ 以上)などの条件で微細に 正確に把握することが肝要である。照射のエネルギー, 形 状や密度は, がん細胞が死㓕し(細胞当り数個の重粒子の 打込みが必要), 他部の正常組織の損傷が極力少ないよう に定められる。治療照射時に患者の表面や内部に検出器を 挿入しておけば, 実際の值が計れる。

その他粒子線ラジオグラフィーへの応用す試みてい $ろ^{(27)}$ 。

（3）方法と結果

(a) 実験のフロー

プラスチック板(検出器)を準備し, 重イオン粒子線を照 射し，短時間化学エッチングし，AFMにて計測し，画像 処理し,エッチピットの形状や感度を解析した。

(b) CR-39検出器

検出器としては, 熱硬化性プラスチック CR-390.85 $\mathrm{mm}$ 厚の板を $10 \mathrm{~mm} \times 10 \mathrm{~mm}$ 角に切った小片を 10 枚ずっ 重ね合わせ束ねた組を 2 組と非照射群を準備した。

(c) 検出器の照射

上記の CR-39 小片を10枚ずつ重ね合わせた 2 組を照射 した。第 1 組は最前方に, 第 2 組は最後方に配位し, その 前方はルサイトにて満たした。第 2 組はブラッグピーク直 前となるように配㯰した。照射は，放医研HIMAC生物照 射系にて, $135 \mathrm{MeV} /$ 核子の単一エネルギー炭素イオン ビームを, 約 $10^{8} / \mathrm{cm}^{2}$ の密度で照射した。これは, 実際の がん治療条件より数10倍高密度な照射である。

(d) エッチング

$\mathrm{NaOH} 27 \%$ 水溶液 $80^{\circ} \mathrm{C}$ で上記検出器を 6 分間のみ化学 エッチングした。通常の光学顕微鏡での観察には 2 時間以 上のエッチング時間を要する。

(e) 原子間力顕微鏡(AFM)による計測

上記エッチングにて得たエッチピットをAFMにて探針 を振動させながら計測するタッピングモードにて観察した 様子を第 II-8,9 図に示す。第 II -9 図では, 飛跡の径が後 方に行くに従いだんだん大きくなっている様子が見られ る。第 II-8 図では, エッチピットのコーン形状が明確に 計測されている様子が見られる。 


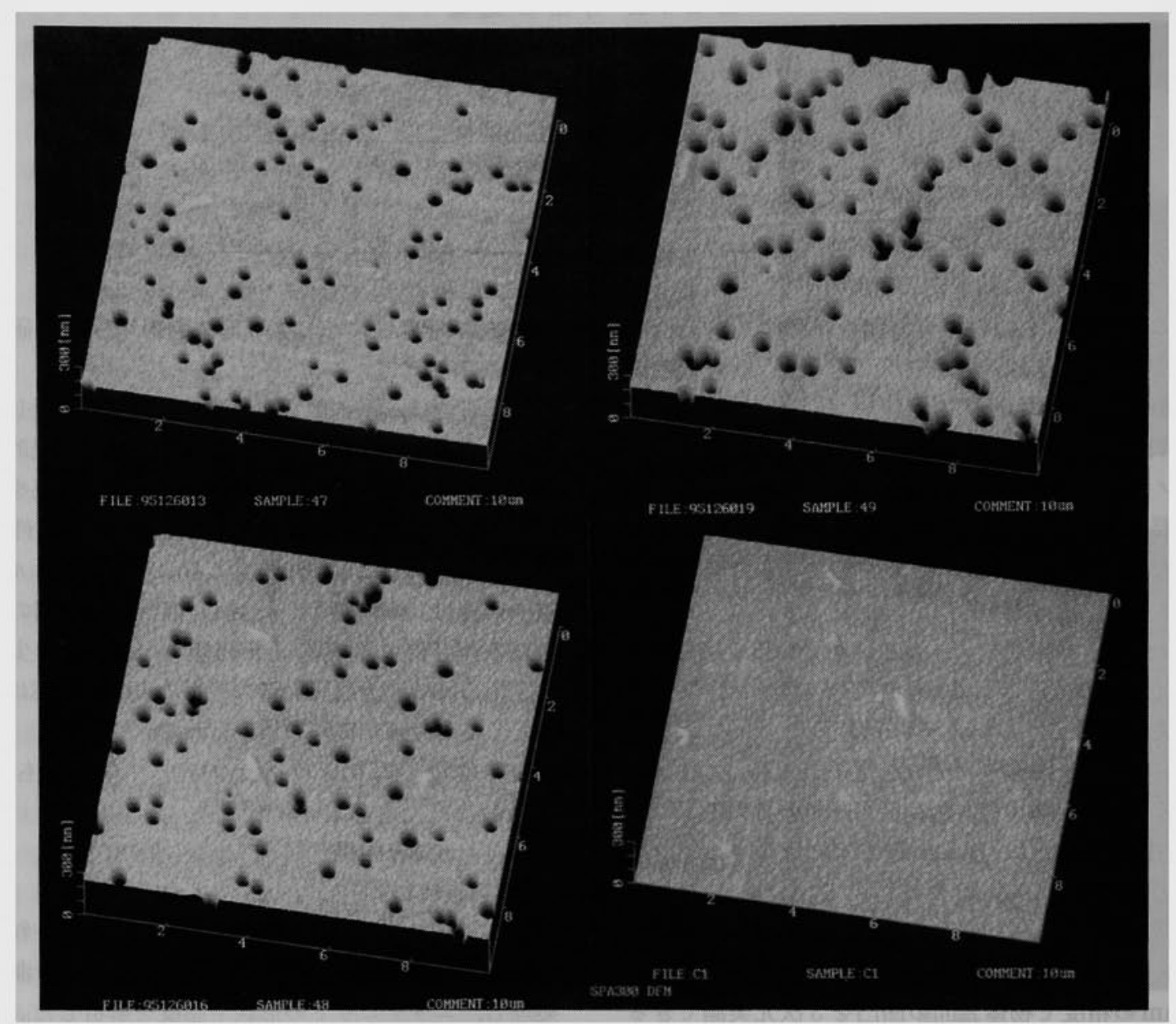

左上：最後部より 2 枚前, 左下：その次,

右上：その次(最後部\#49), 右下：非照射

第 II-9 図 ブラッグピーク付近の AFM像(エッチング 6 分間)

\section{(f) 解 析}

第 II-8 図に示すようなコーン状のエッチピットの直径, 深さを自動画像処理計測し, その半頂角 $\delta$ を求め, LET と 対応する飛跡生成感度を次式により求めた。各パラメータ のヒストグラムを第 2 組の最前 (\#40) と最後(\#49)の 2 枚 について比較のため第 II-10 図に示す。

$$
\text { 感度 } \equiv \frac{[\text { 飛跡エッチング速度 }]}{[\text { バルク・エッチング速度 }]}-1=(\sin \delta)^{-1}-1
$$

第 II-10図に示された各分布は，ともに分布の幅は広い が, エッチングを長くすればするほど，いずれも相対分布 幅は縮まる傾向がある。

(山本幹男)

\section{一参考文献—}

(1) Sonda, N., et al. : Radiology, 148, 833 (1983).

(2) 宮原諒二 : 固体物理, 21, 172 (1986).

(3) 高橋健治, 宮原䛨二 : 結晶誌, 35, 256 (1993).

(4) Niimura, N., et al. : Nucl. Instrum. Methods, A349, 521 (1994).

(5) 森 千鶴夫, 他 : Radioisotopes, 44, 433 (1995).

(6) Mori, C., et al. : Nucl. Instrum. Methods, A313, 39 (1992).
(7) Takebe, M., et al. : Jpn. J. Appl. Phys., 34, 4197 (1995).

(8) 武部雅沉：応用物理, 65, 601 (1996).

（9）新村信雄：“実験化学講座10「回折」”, 第 9 章中性子回折, (日 本化学会編), 丸善, 481 (1992).

(10) Niimura, N., et al. : Nucl. Instrum. Methods, A349, 521 (1994).

(11) 新村信雄 : 原子力工業, 41 [6], 54 (1995).

(12) 新村信雄 : Radioisotopes, 44, 449 (1995).

(13) Niimura, N., et al. : Submitted to J. Neutron Res.

(14) Oed, A. : Nucl. Instrum. Methods, A263, 351 (1988).

(15) Nagae, T., et al. : ibid., A323, 236 (1992); Tanimori, T., et al. : Submitted to Nucl. Instrum. Methods, $\mathrm{A}$, およびこれらの論文中の引用文献.

(16) Sauli, F. : Proc. Int. Workshop on Micro-Strip Gas Chambers, Legnaro, Italy, (1994).

(17) SPring-8 Annu. Rep., (1994).

(18) Price, PB. : Nucl. Tracks Radiat. Meas., 22, 9 21 (1993).

(19) Ogura, K., et al.: Tracking and LET measurements of cosmic ray nuclei for space radiobiological studies, Proc. 3rd Workshop on Physical and Biological Research with Heavy Ions, NIRS-M-99, HIMAC-006 : 24-30, (1993).

(20) Drndic, M., et al. : Nucl. Instrum. Methods, Phys, Res., B93, 52 56 (1994). 

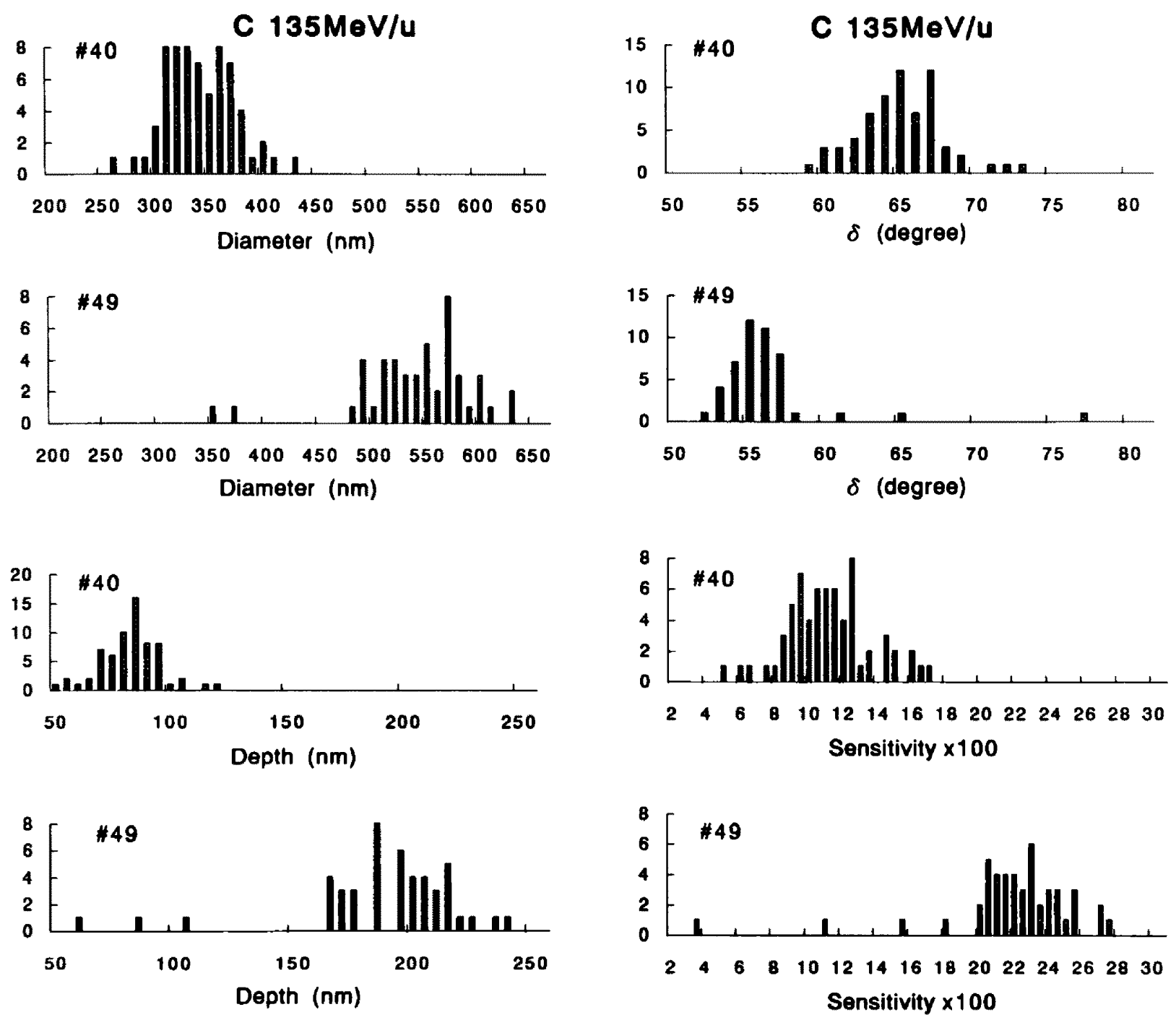

$\# 40$ は第 2 組最前, \#49 は第 2 組最後

第 II-10 図 直径, 深さ, 半頂角 $\delta$ と感度の頻度分布

Q1) Vukovic, JB., Antanasuijevic, R.: Nucl. Tracks Radiat. Meas., 22, 249 250 (1993).

02 Antanasuijevic, R., et al. : Int. J. Radiat. Appl. Instrum., Part D, NT19: 1/4-5*, 555-556 (1991).

(2) 山本幹男, 他：重粒子線効果の微細イメージング解析，平成 6 年度重粒子線がん治澺装置等共同利用研究課題報告書, 放医 研, (1995).

2A Yamamoto, M., et al. : Medical Imaging Technol., 13. 597
598, (1995).

25) 山本幹男, 他：放射線，21〔4]，89～101 (1995).

(26) Yamamoto, M., et al. : CR-39 sensitivity analysis on heavy ion beam with atomic force microscope, 18th Int. Conf. on Nucl. Tracks in Solid, Cairo, Egypt, 1-5 Sep. 1996. The Proceedings will be appeared in Radiation Measurements.

(27) 貝塚洋志，他：原子間力影微鏡を用いた微細ラジオグラフィ, 原子力学会「1996春の大会」要旨集, G8. 


\title{
III. 新しい素材による放射線センシング
}

\author{
日立化成工業石橋 浩之, 倉田 靖, 蔵重 和央, 須佐 憲三, \\ 日本原子力研究所 眠田 重和, 角田 恒巳, 松下㦃業機器侏 馬場 末喜
}

\section{1. 新しいシンチレータ(PET 用を中心に)}

従来， $\mathrm{X}$ 線や $\gamma$ 線などの放射線の検出には, 萤光出力の 高いNaI：Tlシンチレータが用いられてきた。しかし近 年, $\mathrm{X}$ 線 CT (X 線断層撮像装置, $\mathrm{X}$-ray Transmission Computed Tomography)やPET (陽電子放出核種断層撮 像装置, Positron Emission Computed Tomography)に 代表される医療機器の開発に伴い, $\mathrm{CdWO}_{4} や \mathrm{Bi}_{4} \mathrm{Ge}_{3} \mathrm{O}_{12}$ 等 の高密度な単結晶シンチレータが注目され, 実用化されて いる(1)(2)。

これらの医療機器では, どのシンチレータを選ぶかが装 置の性能を向上させる上で, 最も重要な要因の一つであ る。したがって, 進歩の速い医療機器, とりわけPETで は，より高性能な新しいシンチレータが求められている。 高性能なシンチレータを求める分野としては，医療機器以 外に, 物理学研究 (素粒子, 原子核, 宇宙など), 産業用 $\mathrm{CT}$ ，石油探査等の分野がある ${ }^{(3)(4)}$ 。新しいシンチレータに 要求される特性項目はいずれの分野にも共通するものが多 いが，本節では，特にPET用に焦点を当てて最近の単結 晶シンチレータの動向を概説する。

(1) PET 用シンチレータに要求される特性

PETは，サイクロトロンより作られる ${ }^{11} \mathrm{C},{ }^{19} \mathrm{~N},{ }^{15} \mathrm{O},{ }^{18} \mathrm{~F}$ などの陽電子放出核種で標識された放射性薬用を被検体に 投与し，陽電子消隇によって $180^{\circ}$ 方向に放出される $\gamma$ 線 (511 keV)を体外から同時計測して，薬昘の体内分布を画 像化する装置である。放射性薬肪としては，生体と極めて 関係が深い酸素, 水, ブドウ糖などが用いられる。これらの 薬珴の追跡により，従来の X 線 CTではできない，真の生 理学的,生化学的な機能診断が可能となる(2)。

このPETに用いられるシンチレータへの要求特性は,
まず $511 \mathrm{keV} の \gamma$ 線をより小型のシンチレータで検出する 必要から，密度が高い(放射線吸収係数が大きい)ことであ る。また時間分解能を向上させる(偶発同時計数を低減す る)ために，速いシンチレータ，すなわち蛍光減衰時間の 短いシンチレータが望まれる。また最近は，2次元的に配 列した多数のシンチレータのどこに $\gamma$ 線が入射したかを， 4 個の光電子増倍管の出力信号の比から同定する方法が用 いられる。そのため，位置同定の精度向上のために蛍光出 力が大きいこともあらためて必要となっている。

\section{（2）各シンチレータの特性比较}

第 III-1 表は，従来および最近の典型的な単結晶シンチ レータの特性を比較したすのである(5)。なお，耐放射線強 度については，PET用としてはあまり重要な特性ではな いが, 物理研究用で最近重要視されている。

BGOは密度が高いことから，ほとんどのPETで用いら れている。CWOは，高密度ではあるが蛍光減衰時間が長 いことから，主にX線 CTに用いられている。な招最近の $\mathrm{X}$ 線 CT では，本節では述べないが，セラミックシンチ レータす使用されている(6)。

$\mathrm{CsF} や \mathrm{BaF}_{2}$ は，萤光減衰時間が数 ns 以下之非常に短い 特性を利用して， $\gamma$ 線の飛行時間差情報を利用する夕イム オブフライト方式のPETに使用された ${ }^{(2)(7) 。}$

GSO, LSO, YAP, LuAPは, 比較的最近見出されたシン チレータであり，いずれあ $\mathrm{Ce}^{3+}$ が発光中心で蛍光減衰時 間が短く，その出力る比較的高く, PET 用シンチレータ として鬼力的な特性を持っている(8) (12)。また,これらは 耐放射線強度にも優れることから物理研究分野でる期待さ れている(13)。これらはいずれす酸化物の単結晶材料で, 融点が高く単結晶育成が難しいため, 実用化に当っては, 育成技術の確立が必要である。

第 III-1 表 典型的な単結晶シンチレータの特性比較

\begin{tabular}{|c|c|c|c|c|c|c|c|c|c|}
\hline $\begin{array}{l}\text { シンチレータ } \\
\text { (省略名) }\end{array}$ & $\mathrm{NaI}: \mathrm{Tl}$ & $\begin{array}{l}\mathrm{Bi}_{4} \mathrm{Ge}_{3} \mathrm{O}_{12} \\
(\mathrm{BGO})\end{array}$ & $\begin{array}{l}\mathrm{CdWO}_{4} \\
\text { (CWO) }\end{array}$ & $\mathrm{CsF}$ & $\mathrm{BaF}_{2}$ & $\begin{array}{l}\mathrm{Gd}_{2} \mathrm{SiO}_{5}: \mathrm{Ce} \\
\quad(\mathrm{GSO})\end{array}$ & $\begin{array}{l}\mathrm{Lu}_{2} \mathrm{SiO}_{5}: \mathrm{Ce} \\
\quad(\mathrm{LSO})\end{array}$ & $\begin{array}{l}\mathrm{YAIO}_{3}: \mathrm{Ce} \\
\text { (YAP) }\end{array}$ & $\begin{array}{l}\mathrm{LuAIO}_{3}: \mathrm{Ce} \\
\text { (LuAP) }\end{array}$ \\
\hline 密度 $\left(\mathrm{g} / \mathrm{cm}^{3}\right)$ & 3.67 & 7.13 & 7.90 & 4.64 & 4.89 & 6.71 & 7.4 & 5.55 & 8.34 \\
\hline $\begin{array}{cc}\text { 蛍光滅衰時間 fast } \\
\text { (ns) } & \text { slow }\end{array}$ & 230 & 300 & 5,000 & 2.8 & $\begin{array}{l}0.6 \\
620\end{array}$ & $\begin{array}{c}30 \sim 60 \\
600\end{array}$ & 41 & 28 & 17.9 \\
\hline $\begin{array}{l}\text { 虽光出力 } \\
\text { (相対值) }\end{array}$ & 100 & $7 \sim 10$ & $30 \sim 40$ & 6 & $\begin{array}{c}5 \\
16\end{array}$ & $\begin{array}{c}18 \\
2\end{array}$ & 75 & 40 & 40 \\
\hline $\begin{array}{cr}\text { 発光波長 } & \text { fast } \\
\lambda_{\text {rm }}(\mathrm{nm}) & \text { slow }\end{array}$ & 415 & 480 & 480 & 390 & $\begin{array}{l}210 \\
310\end{array}$ & $\begin{array}{l}430 \\
430\end{array}$ & 420 & 347 & 365 \\
\hline 屈折率 (at $\lambda_{e m}$ ) & 1.85 & 2.15 & 2.25 & 1.48 & 1.56 & 1.85 & 1.82 & 1.94 & 1.94 \\
\hline 耐放射線強度（rad） & $10^{3}$ & $10^{4 \sim 5}$ & $10^{8}$ & $10^{4}$ & $10^{6 \sim 7}$ & $10^{9}$ & $10^{8}$ & $10^{6}$ & - \\
\hline $\begin{array}{l}\text { 昅湿潮解性 } \\
\text { 融 点 }\left({ }^{\circ} \mathrm{C}\right)\end{array}$ & $\begin{array}{l}\text { 強 } \\
651\end{array}$ & $\begin{array}{l}\text { なL } \\
1,050\end{array}$ & $\begin{array}{l}\text { なし } \\
1,300\end{array}$ & $\begin{array}{l}\text { 強 } \\
682\end{array}$ & $\begin{array}{l}\text { なし } \\
1,354\end{array}$ & $\begin{array}{l}\text { なし } \\
1,950\end{array}$ & $\begin{array}{l}\text { なし } \\
2,150\end{array}$ & $\begin{array}{l}\text { なし } \\
1,850\end{array}$ & $\begin{array}{c}\text { なし } \\
1,960\end{array}$ \\
\hline
\end{tabular}




\section{（3）単結晶シンチレータの製造方法}

シンチレータの機能は, 放射線の入射によって蛍光を発 することに加えて, その光を光電变換素子に効率よく伝え るという役目がある。したがって, シンチレータは蛍光に 対して吸収や散乱のない透明で光学的に良質な材料でなけ ればならない。このようなシンチレータは，最適な育成条 件のもとで製造される単結晶によって実現される。

単結晶シンチレータの製造方法は, チョクラルスキー法 かまたはブリッジマン法のどちからの方法で育成され $3^{(14)}$ 。

GSO は, チョクラルスキー法で育成されるが, 異方性 が大きく, へき開性を有することなどから, 単結晶育成時 に割れる問題があった。しかし最近, 割れの問題が解決 し, 良質な大型単結晶が得られるようになった ${ }^{(15)}$ 。第 III1 図に, $\phi 80 \times 280 \mathrm{~mm}$ の GSO 単結晶の写真を示す。GSO はすべての特性にバランスのとれたシンチレータで, 現在 石油探查用に使われているが(16), 今後の他分野での採用 が期待される。

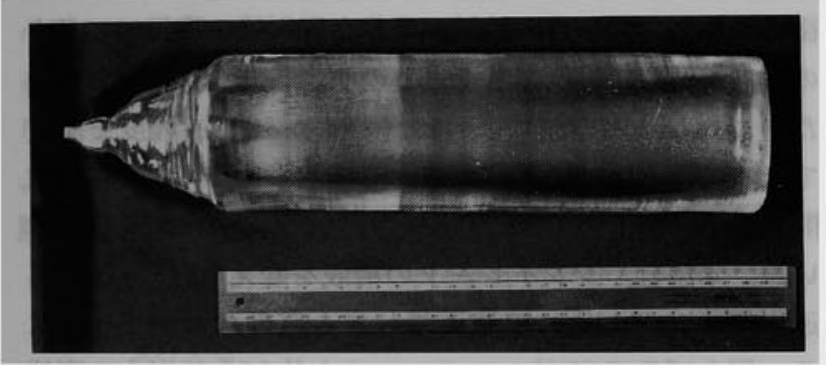

第 III-1 図 $\phi 80 \times 280 \mathrm{~mm}$ GSO単結晶

LSO は GSO と同様にチョクラルスキー法で育成され る ${ }^{(9)}$ 。融点が高く, 育成が難しいことに加えて, 希少原料 の $\mathrm{Lu}_{2} \mathrm{O}_{3}$ が高価なことと天然に含まれる ${ }^{176} \mathrm{Lu}$ が放射性を 示す問題がある(5)。LSO はすべての特性に優れるすばら しいシンチレータであることから, 今後の大型単結晶育成 技術の開発および原料価格の低減が待たれる。

YAP, LuAPはチョクラルスキー法とブリッジマン法の いずれの方法であ単結晶育成が試みられているが, 別組成 の結晶ができやすい問題がある(11)(12)。これらはまだ見出 されて間あないこともあり，今後に期待したい。

(4) まとめ

PET 用を中心に最近のシンチレータを概説した。最近 見出されたシンチレー夕はいずれも優れた性能を有する が, 良質の大型単結晶が得られ, 実用的な価格で供給でき ることが今後の課題である。結晶工学的な研究開発が引き 続き活発に行われ, シンチレータのユーザとメーカが共に 発展することを希望したい。

（石橋浩之, 倉田 靖, 藏重和央, 須佐害三）

\section{2. 放射線を弁別する一ホスウィッチ検出器と 光学フィルタの利用}

$\alpha$ 線を含む複数の放射線を弁別して，同時計測するモ二 夕用検出器ホスウィッチの開発が進められている(1) (22)。 このホスウィッチは，それぞれの放射線に対し選択的な感 度を有し, かつ減衰時間が適当に異なる複数のシンチレー 夕を組み合わせて，波高および波形弁別により同時計測す る。この際, 光学フィルタを利用して波高および波形をコ ントロールすれば，さらに優れた弁別となる(20) (24)。第 III-2 図に，光学フィルタを利用したホスウィッチ検出器 の 1 例を示す。

減衰時間の荤い $\alpha$ 線検出用 $\mathrm{ZnS}(\mathrm{Ag})$ と速い $\beta(\gamma)$ 線検出 用 NE102A から成るホスウィッチは, CsI(T1)等の単一シ ンチレータよりはるかに優れた $\alpha-\beta(\gamma)$ 波形弁別特性を示 す ${ }^{(17)}$ 。第 III -3 図は濃縮ウラン溶液試料の立上がり時間ス ペクトルである。 $\alpha$ 線の立上がり時間のゆらぎが大きく なっているが，溶液試料に対してあ極めて良好な分解能を 示し, 濃度モ二夕用同時計測検出器してあ満足できる ${ }^{(18)}$ 。

しかし, $\mathrm{ZnS}(\mathrm{Ag})$ と NE102A のように発光量がかなり 異なる場合, 双方の波高をダイナミックレンジ内に収める ことが困難になることがある。このような場合，第 III-2 図に示したように, $\mathrm{ZnS}(\mathrm{Ag})$ からの光量を ND フィル夕 を用いて抑えることにより, 波高を調節する。この例で は, NDフィルタの付加により， $\alpha$ 線とソフト $\beta(\gamma)$ 線の同 時計測が可能になった ${ }^{(19)(20)}$ 。

$\alpha$ 線と熱中性子 $n_{\mathrm{th}}$ を弁別するには, $\mathrm{ZnS}(\mathrm{Ag})$ と ${ }^{6} \mathrm{Li}$ ガラ スを用いる( ${ }^{(21)}$ 。 ${ }^{6} \mathrm{Li}\left(n_{\mathrm{th}}, \alpha\right)$ 反応の $Q$ 値 $(4.8 \mathrm{MeV})$ は大きい ので, $\beta(\gamma)$ 線から $n_{\mathrm{th}}$ のみを容易に波高弁別できる。しか

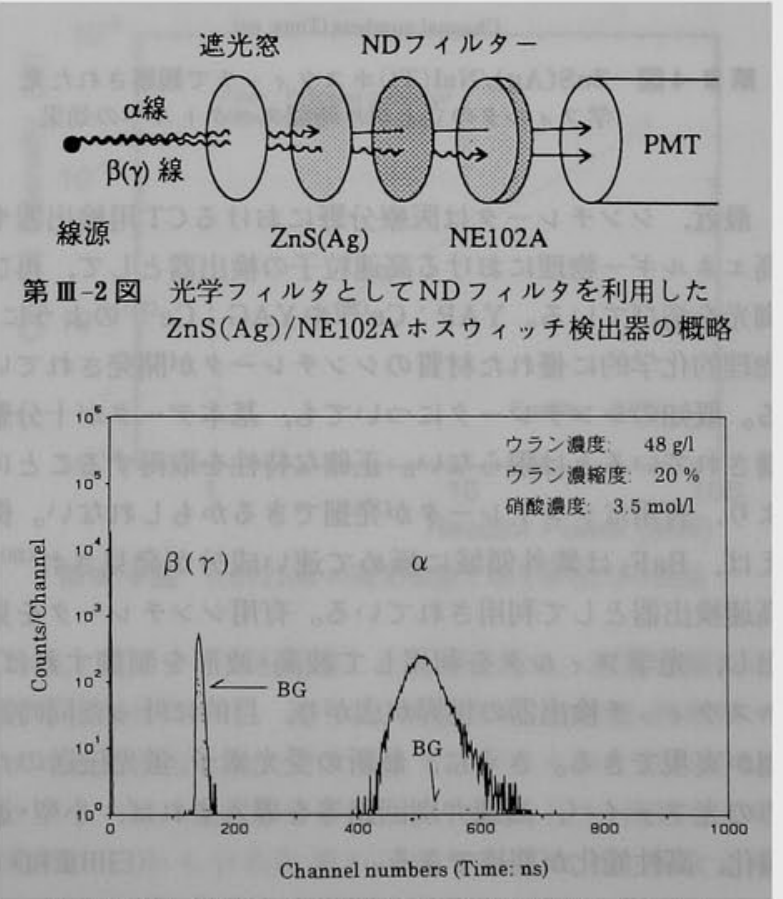

第 III-3 図 濃縮ウラン溶液の立上がり時間スペクトル 
し, $\mathrm{ZnS}(\mathrm{Ag})$ の発光量が多いため, $\alpha$ 線の波高分布は $n_{\mathrm{th}}$ ピークと重なる。そこで, NDフィルタを用いて $\alpha$ 線波高 を低下させ， $n_{\mathrm{th}}$ のみを波高弁別する。一方， $\alpha$ 線は $\beta(\gamma)$ 線および $n_{\text {th }}$ から波形并別する。

$\alpha, \beta(\gamma)$ 線および速中性子 $n_{\mathrm{f}}$ の弁別には, $\mathrm{ZnS}(\mathrm{Ag})$ と $\beta(\gamma)-n_{\mathrm{f}}$ 波形弁別が可能なアントラセン，スチルベンまた はNE213等を用いるとよい(22)。さらに， $\alpha, \beta(\gamma)$ 線, $n_{\mathrm{f}}$ およ び $n_{\mathrm{th}}$ すべての弁別には，例えば $\mathrm{ZnS}(\mathrm{Ag}),{ }^{6} \mathrm{Li}$ ガラスおよ びアントラセンの組合せが可能になる。

$\mathrm{ZnS}(\mathrm{Ag})$ は異なる発光スペクトル有する複数の減衰成 分を持つと思われ(25), シャープカット,バンドパス等の光 学フィルタを透過して観測される出力パルスの立上がり時 間は，その透過特性に応じて変動することがわかっ た (22) (24)。すなわち，このような光学フィルタを利用すれ ば，立上がり時間をある程度調整することができる。一例 として, $\mathrm{ZnS}(\mathrm{Ag})$ と $\mathrm{NaI}(\mathrm{Tl})$ 加ら成るホスウィッチに中 心波長 $420 \mathrm{~nm}$ のシャーブカットフィル夕を利用した立上 がり時間スペクトルを第 III-4 図に示す。光学フィルタの 効果により $\alpha$ 線と $\beta(\gamma)$ 線の波形弁別特性加改善されてい る。

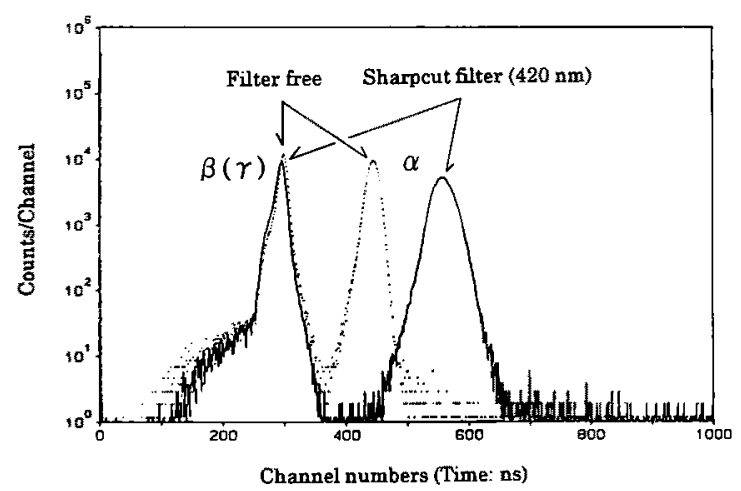

第 III-4 图 $\mathrm{ZnS}(\mathrm{Ag}) / \mathrm{NaI}(\mathrm{Tl})$ ホスウィッチで観察された光 学フィルタの立上がり時間スペクトルへの効果

最近, シンチレータは医療分野におけるCT 用検出器や 高エネルギー物理における高速粒子の検出器として, 再び

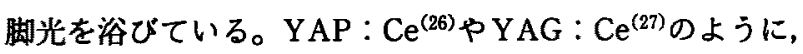
物理的化学的に優れた材質のシンチレータが開発されてい る。既知のシンチレータについても，基本データが十分整 備されているとは限らない。正確な特性を取得することに より，有用なシンチレータが発掘できるかすしれない。例 元ば， $\mathrm{BaF}_{2}$ は紫外領域に極めて速い成分が発見され(28)， 高速検出器として利用されている。有用シンチレータを見 出し, 光学フィルタを利用して波高・波形を制御すれば, ホスウィッチ検出器の世界が広がり、目的に叶った同時計 測が実見できる。さらに, 最新の受光素子, 蛍光伝送のた めの光ファイバ，高速弁別回路等を導入すれば，小型·遠 隔化，高性能化が期待できる。

（兒田重和）

\section{3. 光ファイパによる放射線センシング}

フレキシビリティに富み，軽量細径の特長を持つ光つっ イバを，伝送媒体のみでなく，放射線センサーとして利用 する試みが数多く進められており, 実用化へのレベルも高 い。その形態は，大きく分け 2 通りの方法がある。一つ は, 光ファイバに小型のシンチレータを取り付け, 微弱な 信号光を光ファイバを通して伝送するタイプであり，他の 方法は，光ファイバ自身をセンサー要素とするタイプであ る。いずれもせンサーおよび伝送媒体に電源を必要とせ ず，信号光を遠方まで伝送することができる特長を有して いる。

前者の例として, 光ファイバの先端に $\mathrm{ZnS}(\mathrm{Ag})$ シンチ レータと ${ }^{6} \mathrm{Li}$ の化合物 $\mathrm{LiOH}$ 染布し, 熱中性子束分布を测 定した結果を第 III-5 図に示す ${ }^{(29)}$ 。本例は, 京大の臨界実 験装置の炻心中央部分において, 燃料体間の $2 \sim 3 \mathrm{~mm}$ の 間隙を燃料体に沿って,この光ファイバ形センサーを走查 したものである。測定結果は，同図(a)に示すように，従来 より行われている金線の放射化法とよい一致をみている。 従来の放射化法では, 試料の調整と照射後の取扱いに多く の労力を要し, 最低でも 4 5h の测定時間を必要としてい たのに対し，本方法によれば，わずか $10 \mathrm{~min}$ 程度で測定 できる。さらに，同図(b)に拡大部を示すように，燃料構造 間の微細な熱中性子束分布をあ測定できる分解能を有して いる。本法は, シンチレータの構成を変えれば, $\gamma$ 線や高 速中性子など，他の線種に対しても有効なセンサーとな る。例えば $\mathrm{ZnS}(\mathrm{Ag})$ シンチレータと約 $1 \mathrm{MeV}$ 以上の高速 中性子に反応断面皘を持っ ${ }^{232} \mathrm{Th}$ を用いれば，高速中性子 束の測定が可能である。
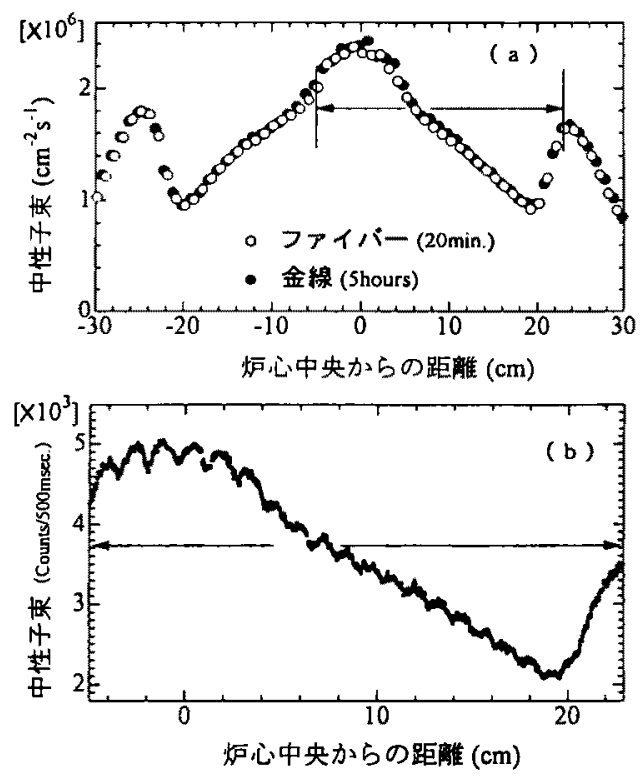

(a) 金線法との比較，(b) 炉心中央部の微細分布

第 III-5 图 $\mathrm{ZnS}(\mathrm{Ag})-{ }^{6} \mathrm{LiOH}$ シンチレータ付光ファイバセン サーで京大陻界実験装置の炉心の熱中性子束分布 を測定した結果 
ところで, シンチレータの発光波長は, 多くの場合 400 〜 430 nm の短波長領域にあるため, 伝送距離が長くなる と光ファイバの特性から損失が大きくなり, 効率と $S / N$ の点で不利になる。そこで, 蛍光性光ファイバ(波長シフ トファイバ)を用いて $500 \mathrm{~nm}$ 領域に波長変換し損失を低減 する方法が提案されている。波長シフトファイバをシンチ レータ中心軸に挿入したタイプのあのと ${ }^{(30)(31)}$, シンチ レータ端面に取り付けたもの ${ }^{(31)}$ があり, 信号光は光ファ イバで伝送するシステムである。第 III-6 図に波長シフト ファイバを用いたセンサーを示す(31)。このセンサーを数 個所に㯰き, 1 本の光ファイバで結び光飛行時間(TOF)法 を併用すれば，放射線の空間分布測定が可能である。この 方法では, 大型のシンチレータを用いることができるの で, 高い検出効率が得られる。また, 細径の光ファイバは 半導体光センサーとの組合せが容易であるため, 電子回路 の小型軽量化とともに, 波長シフトにより半導体光セン サーの高感度な波長帯で使用することができる。

光ファイバ自身を放射線センサー要素としたタイプの代 表的な例として, プラスティックシンチレーションファイ バ(PSF)がある。PSF 自身がセンサーと伝送媒体を兼ね るので, TOF 法を適用することで分布测定が可能であ $\eta^{(32)(33)}$, 約 $30 \mathrm{~cm}$ の位置分解能が得られている。本法に より，原子力施設内で実際に線量分布測定を行った結果を 第 III-7 図に示す ${ }^{(33)}$ 。プラスチックファイバは石英系ファ

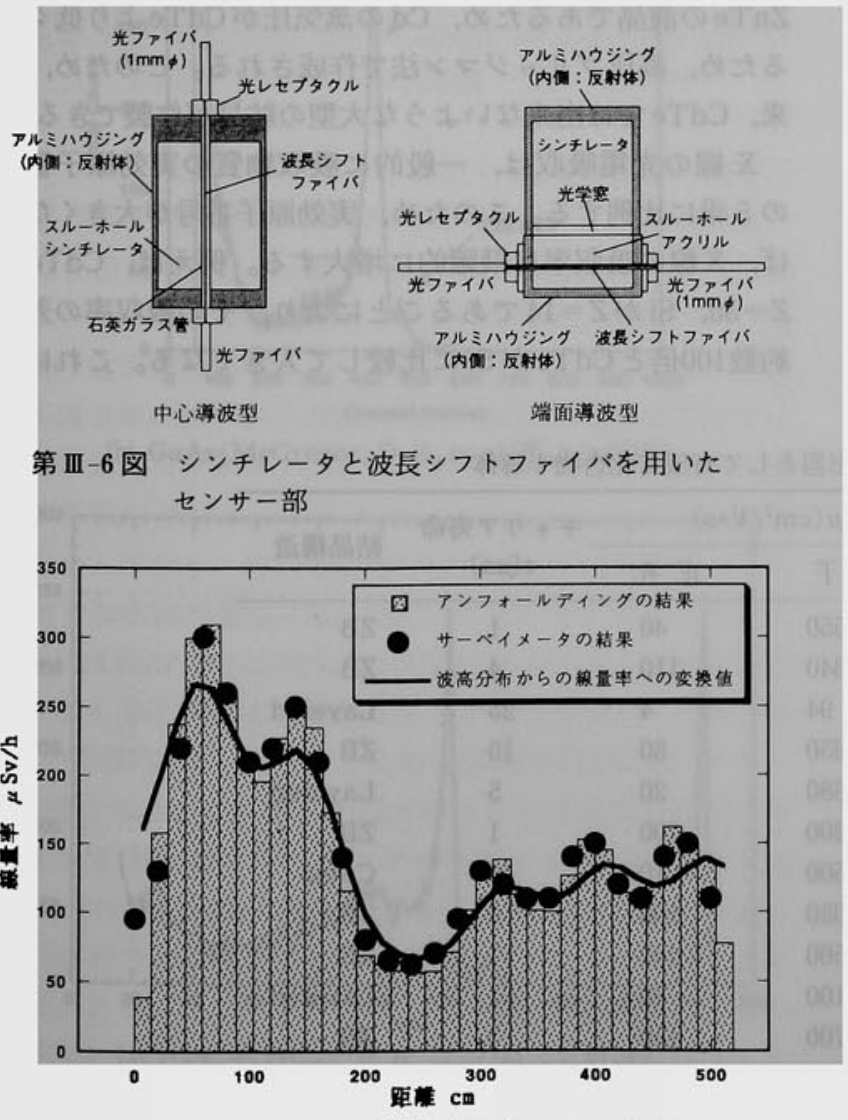

第 III-7 図 原子力施設内での放射線分布測定結果
イバに比べ伝送損失が大きく，また偶然の同時計数の影響 から, 測定位置により感度差を生じる場合があるので, あ らかじめシステムの応答関数を求めておき, アンフォール ディングによって補正すると, サーベイメータで得られた 結果とよく一致する。

最近は, 石英系光ファイバの耐放射線性が各段に進展し ており，原子炬の炉心近傍で十分実用に供せるようになっ てきた ${ }^{(34)}$ 。光ファイバ自身をセンサー要素とする利用技 術として, 原子炉出力を測定する試みがなされている(35)。 光ファイバからのチェレンコフ発光, $\mathrm{Si}$ 格子結合に関わ ると考えられる長波長 $(1,270 \mathrm{~nm}$ 帯)の発光ピークなどを 利用する方法である。第 III-8 図は, JMTR 炬心での光 ファイバの発光特性を示す。700 $1,700 \mathrm{~nm}$ の幅広い波長 領域のチェレンコフ光と, $1,272 \mathrm{~nm}$ に鋭い発光ピークが 観察され，第 III-9 図に示すように，1,272nmピーク值と 原子炉出力の関係は，良好な比例関係にある。

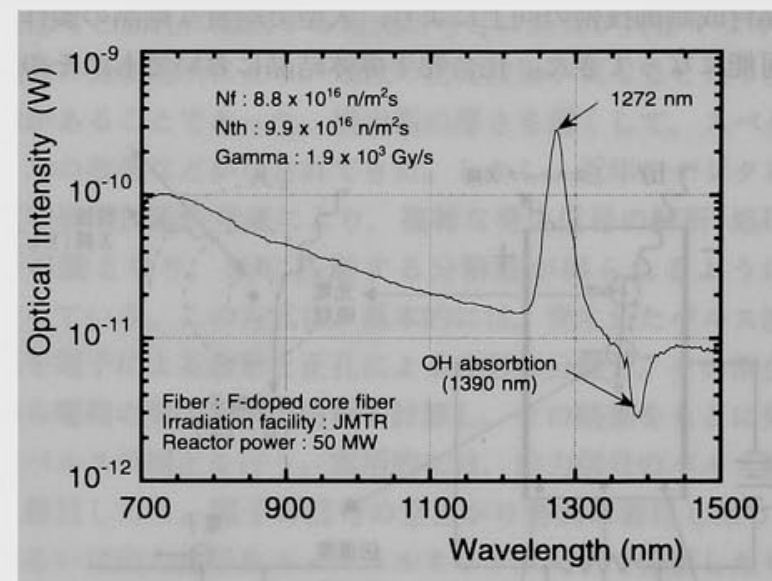

第 III-8 図 JMTR炉心で照射中の光ファイバからの発光 スペクトル

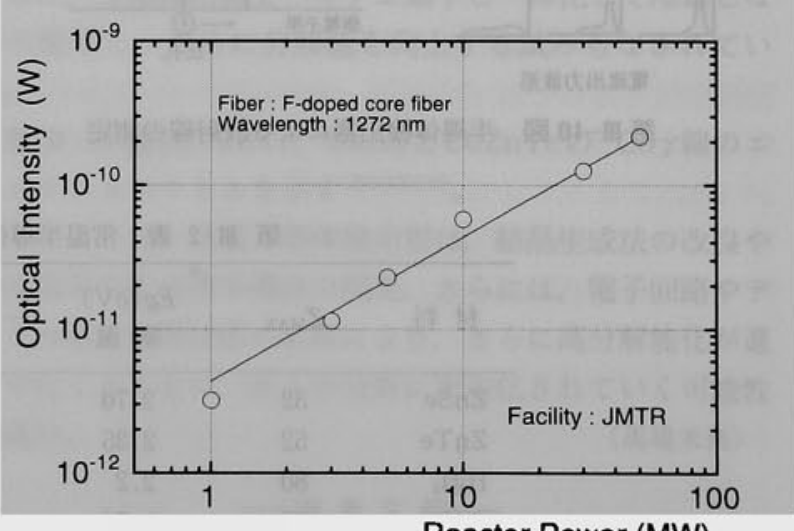

Reactor Power (MW)

第 III-9図 1,272nm の発光強度と原子炉出力の関係

今後，光ファイバを利用した計測技術は，耐放射線性の 更なる進展に伴って, 原子炉, 核融合炬, 加速器, 核燃料サ イクル施設などにおいてますます広がるすのと思われる。 光ファイバは, 放射線のみならず, 温度, 圧力, 流量などを 同時に, しかす分布計測が可能であるので, 多次元の Multi function計測へと発展が期待される。（角田恒巳） 


\section{4. 高分解能化が進む常温半導体検出器}

放射線センサー用の半導体材料としては，長く周期律表 のV族の $\mathrm{Si}$ と Geが多く使用されてきた。しかし，この材 料は，バンドキャップが低いため，常温での熱ノイズが大 きく，高い分解能を得るためには冷却する必要がある。常 温で使用できるバンドキャップの条件を渵たすために，単 元素物質では得られない特性を化合物半導体で得ることが できる。第 III-2 表に, 常温使用可能な代表的な化合物半 導体の物性の一覧を示す。これらの材料は数10年にわたり 多くの研究がなされてきたが、実用化されているのは数種 類のちのである ${ }^{(36) \sim(38) 。}$

半導体検出器による放射線の湘定は，第 III-10 図に示す ように，半導体結晶内に入射した放射線によって発生した 電荷を収集し，電気信号として出力することである。分解 能はこの収集効率の均質性と安定性に依存する。近年, 結 晶育成制御技術の向上により，大型で均質な結晶の製作が 可能になってきた。化合物半導体結晶においても，その技

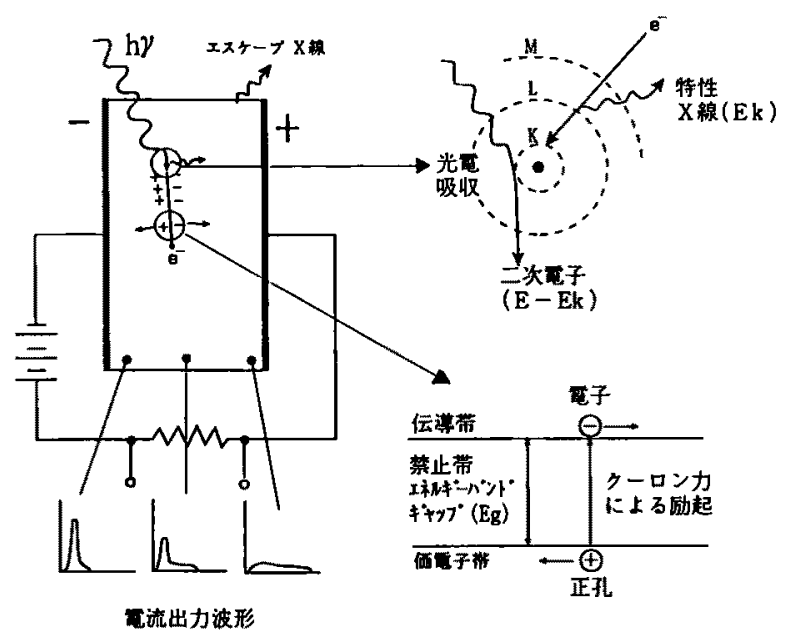

第 III-10 図 半導体検出器による放射線の測定
術の応用により, 優れた結晶が作られ, 分解能を向上させ ている。とくに, CdTeは, Cdの蒸気圧が高いため, 欠 宿の少ない大型の結晶の製作が困難であったが, THM法 (Travering Heater Method)が開発されたことにより， 実用的な結晶が使用できるようになった。これはCdの蒸 気圧が高いとCd の欠陥が発生しやすくなるため, 結晶成 長の温度をできるだけ低い状態で生成するために考えられ たものである。低温で溶融する $\mathrm{Te}$ の溶液ソーンを多結晶 の CdTe 中で移動させ, 単結晶を生成する。欠点として は，結晶生成速度が非常に遅いことと結晶方位の制御が難 しいことである。結晶欠宿は，電子や正孔のトラップ中心 となり，分解能の低下や感度のドリフトの原因となる。 THM法の開発により, 久陥の少ない結晶の作成が可能と なったため，CdTeが実用化されるようになったといって あ過言ではない。近年, 直径 2 in. 程度の大型の CdTe結晶 が生産されるようになり，2 次元画像用センサーとして実 用化されてはじめている。

衛星通信や携帯電話など超高周波領域で急速に応用範囲 が拡大しているGaAsは，Geに匹敵する電気的な物性值 を有しているため注目されてきた。近年, 結晶欠宿とスペ クトル分解能との関係が明らかにされるようになり, 実用 的な結晶の製作が可能になってきている( ${ }^{(39) 。}$

一方, 2 元系の材料の欠点を改善するために，多元系の 材料の開発が進められている。CdZnTeは近年，実用化さ れ始めている代表的なものである。この結晶は CdTe と $\mathrm{ZnTe}$ の混晶であるため, Cdの蒸気圧が CdTeより低くな るため, 高圧ブリッジマン法で作成される。このため, 従 来, CdTeでは出来ないような大型の結晶が作製できる。

$\mathrm{X}$ 線の光電吸収は，一般的に吸収物質の実効原子番号 の 5 乗に比例する。このため，実効原子番号が大きくなれ ば，X線の吸収率は飛躍的に增大する。例えば，CdTeが $Z=50, \mathrm{Si}$ が $Z=14$ であることにより，その吸収率の差は 約数100倍とCdTeがSiに比較して大きくなる。これによ

第 III-2 表 常温半導体検出器として有望な化合物半導体

\begin{tabular}{|c|c|c|c|c|c|c|}
\hline \multirow{2}{*}{ 材 料 } & \multirow{2}{*}{$Z_{\text {MAX }}$} & \multirow{2}{*}{$\begin{array}{c}E g(\mathrm{eV}) \\
\text { 室 温 }\end{array}$} & \multicolumn{2}{|c|}{$\mu\left(\mathrm{cm}^{2} / \mathrm{V} \cdot \mathrm{s}\right)$} & \multirow{2}{*}{$\begin{array}{c}\text { キャリア寿命 } \\
\tau(\mu \mathrm{s})\end{array}$} & \multirow{2}{*}{ 結晶構造 } \\
\hline & & & 電 子 & 正 孔 & & \\
\hline $\mathrm{ZnSe}$ & 32 & 2.70 & 550 & 40 & 1 & ZB \\
\hline $\mathrm{ZnTe}$ & 52 & 2.25 & 340 & 110 & 4 & ZB \\
\hline $\mathrm{HgI}_{2}$ & 80 & 2.2 & 94 & 4 & 25 & Layered \\
\hline CdSe & 48 & 1.74 & 650 & 50 & 10 & ZB \\
\hline $\mathrm{BI}_{3}$ & 80 & 1.7 & 680 & 20 & 5 & Layered \\
\hline AISb & 51 & 1.62 & 1,200 & 700 & 1 & ZB \\
\hline $\mathrm{Cs}_{3} \mathrm{Sb}$ & 55 & 1.6 & 500 & 10 & 40 & Cubic \\
\hline $\mathrm{CdTe}$ & 52 & 1.50 & 1,050 & 100 & 6 & ZB \\
\hline GaAs & 32 & 1.45 & 8,500 & 450 & 1 & $\mathrm{ZB}$ \\
\hline $\mathrm{WSe}_{2}$ & 74 & 1.36 & 100 & 80 & 1 & Layered \\
\hline InP & 49 & 1.35 & 4,700 & 150 & 3 & ZB \\
\hline $\mathrm{Si}$ & 14 & 1.115 & 1,350 & 480 & & Cubic \\
\hline $\mathrm{Ge}$ & 32 & 0.665 & 3,900 & 1,900 & & Cubic \\
\hline
\end{tabular}


り，同一の検出効率を得ようとする場合に，検出器の厚さ をそれだけ薄くすることができる。このため，発生した電 荷の移動距離が短くなり，結晶内での電子之正孔の再結合 の確率は減少し，優れた分解能を実現できる。

また，X 線のエネルギースペクトル測定においては， 半導体物質の実効原子番号はさらに優れた特性を示す。つ まり, 光電効果では, 入射エネルギーから半導体物質の $\mathrm{K}$ 電子の結合エネルギーを引いた残りのすべてのエネルギー を吸収した 2 次電子と, 少し遅れてこの $\mathrm{K}$ 電子が基底状

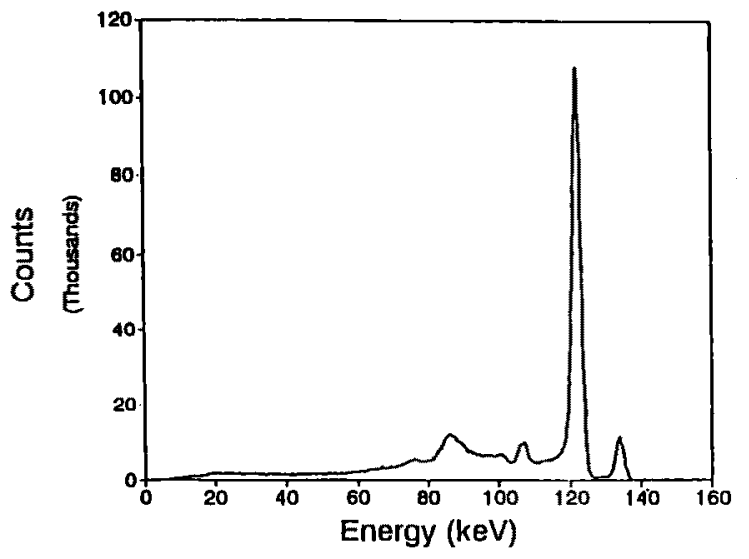

(a) CdTe(Redus, R., et al. ${ }^{(42)}$ より引用)

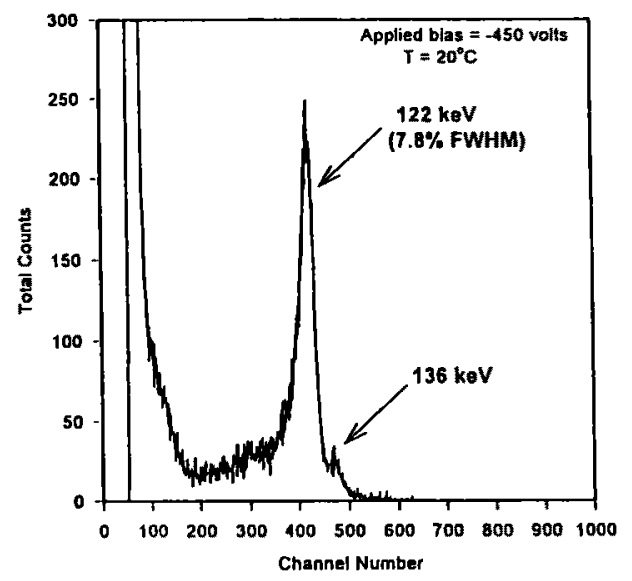

(b) GaAs(McGregor, D. S., et al. ${ }^{(39)}$ より引用)

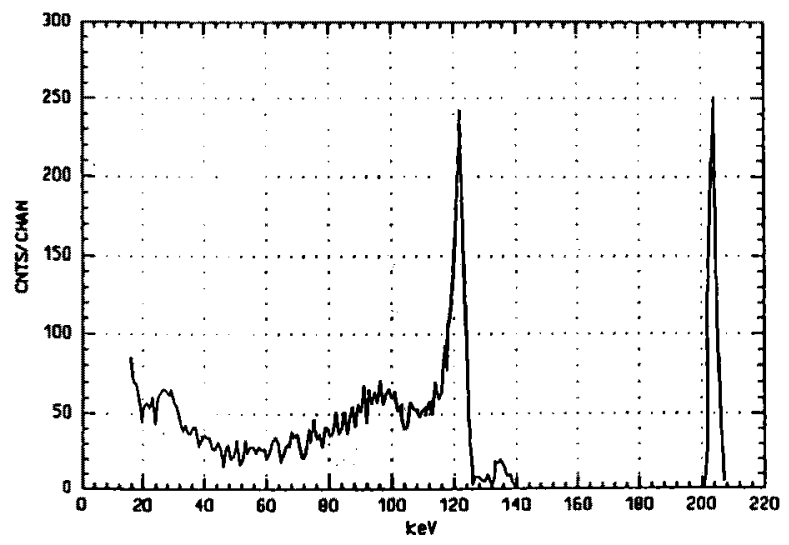

(c) CdZnTe(Doty, F. P., et al. (41) より引用)

第 III-11 図 代表的な常温半導体検出器の $\gamma$ 線スペクトル $\left({ }^{57} \mathrm{Co} 122 \mathrm{keV} \gamma\right.$ 線)
態になるときに発生するエネルギ一の低い特性 X 線とが 生じる。2 次電子と特性 X線は, 飛程が短く発生した近傍 で吸収される。このために，小型の検出器であっても半導 体の有感領域内で入射したすべてのエネルギーを電荷に変 換することができる。このように，X線のエネルギー測定 には, 光電効果の大きな材料, つまり実効原子番号の大き い材料が有利であることがわかる。

半導体物質の実効原子番号が大きくなると，K電子の特 性 X線のエネルギーも大きくなるので, 検出器の周辺で のエスケープが大きくなるが, エスケープは検出器の形状 により決定されるものであるので，補正が可能となる。

常温半導体検出器材料の実効原子番号は32 52 と Si に 比較して高く，以上のような特徴が生かされる分野におい て急速に実用化が進んでいる。

常温半導体桱出器のスペクトルの高分解能化の課題とし て, 電子·正孔の移動度の差が大きく, 電子に起因する電 流信号と正孔に起因する電流信号とに差異が大きくなり, 電荷の発生場所により, 電流の出力波形が異なるという現 象があることであった。検出器の厚さを薄くして、スベク トルの改善などがなされてきた。しかし，近年のデジタル 信号処理技術の発展により, 複雑な発生信号の解析・処理 が可能となり，Si に匹敵する分解能が得られるように なっている。この方式は, 基本的には, 発生したパルス波 形を電子による波形と正孔による波形に分離し，その割合 加電荷の発生場所の情報を計算し，その結果をむとに発 生パルスの補正を行う。実用的には, 出力信号のパルス幅 に着目したり，電子の信号の立上がり時間に着目したり， あるいは出力波形を二ューラルネットワークで分類したり するなどの方法が報告されている。

また, 常温検出器をペルチェ素子と一体化して冷却しな がら使用し、さらに分解能を向上する試みるなされてい る。

第 III-11 図に, CdTe, GaAs と CdZnTe ${ }^{57} \mathrm{Co} \gamma$ 線のエ ネルギースペクトルを示す(39)(40)(42)。

このように, 常温半導体検出器は, 結晶生成法の改良や 多元素系の化合物半導体の開発, さらには, 電子回路やデ ジタル信号処理技術の応用により,さらに高分解能化が進 んで行くととむに，多くの分野に実用化されていく可能性 が高い。

(馬場末喜)

\section{一至考文献一}

(1) 矢野重信, 他：電子技術，23[10]，44 (1981).

(2) 井上慎一：放射線，19[1]，71 (1992).

(3) Ishii, M., Kobayashi, M. : Prog. Crystal Growth Charact., 23, 245 (1991).

（4）谷本慶哲，他：精密工学誌, 56, 1386 (1990).

(5) 小林正明, : 放射線, 20 [2], 41 (1994).

(6) Yoshida, M., et al. : Jpn. J. Appl. Phys., 27, L1572 (1988).

(7) Mullani, N. A. : IEEE Trans. Nucl. Sci., NS-27, 572 (1980).

(8) Ishidashi, H., et al. : ibid., NS-36, 170 (1989). 
(9) Melcher, C. L., Schweitzer, J. S. : Nucl. Instrum. Methods, A314, 212 (1992).

(10) Baryshevsky, V. G., et al. : ibid., B58, 291 (1991).

(11) Lempicki, A. : IEEE Trans. Nucl. Sci., NS-42, 280 (1995).

(12) Moses, W. W., et al. : ibid., NS-42, 275 (1995).

(13) Kobayashi, M., Ishii, M. : Nucl. Instrum. Methods, B82, 85 (1993).

(14)石井满, 他: 放射線, 14 [1]，41 (1987).

(15) Kurata, Y., et al. : IEEE Trans. Nucl. Sci., NS-42, 1038 (1995).

(16) Melcher, C. L. : ibid., NS-38, 506 (1991).

(17) Usuda, S. : J. Nucl. Sci. Technol., 29, 927 (1992).

(18) Usuda, S., et al. : ibid., 31, 73 (1994).

(19) idem: Nucl. Instrum. Methods, A340, 540 (1994).

(20) idem : J. Alloys Compounds, 213/214, 437 (1994).

(21) idem: Nucl. Instrum. Methods, A356, 334 (1995).

(22) 曰细重和：放射化学討論会講演予稿集, p.327 (1995).

(20) 曰细重和, 他：原子力学会[1994春の年会」要旨集、M46.

(24) 白田重和, 他 : 同「1994秋の大会」予稿集(第 1 分冊), E21.

(25) 伊藤 浩, 他: 同 上, E22

(26) Baryshevsky, V. G., et al. : Nucl. Instrum. Methods, B58, 291 (1991).

(77) Moszynki, M., et al. : ibid., A345, 461 (1994).

(28) Laval, M., et al. : ibid., 206, 169 (1983).
(29) Mori, C., et al. : J. Nucl. Sci. Technol., 31 [3], 248 (1994).

(30) 浦山勝巳, 他: “先端基礎研究センターワークショップ, 光 ファイバーの量子計測への応用”論文集，JAERI-conf95-002， p.19 (1995).

(31) 前川立行：放射線，21〔3],69 (1995).

(32) Soramoto, S., et al.. : Radiation detectorsand their uses, KEK Proc. 93-8, June 1993, p.171.

(33) 江本武彦, 他 : JAERI-conf 95-002, p. 14 (1995).

(34) 角田恒已, 他：JAERI-conf 95-002, p.28 (1995).

(35) 坂佐井堅, 他：“先端基礎研究シンボジウム”满演概要集, P-59, (1995).

(36) Sakai, E. : Nucl. Instrum. Methods, 196, 121 130 (1982).

(37) 田口常正：センサ技術，6 (11)，(1986).

(38) Armantrout, et. al. : IEEE Trans. Nucl. Sci., NS-24, 121 (1977).

(39) Mcgregor, D. S., et al.. : To be published in Nucl. Instrum. Methods, 1996.

(40) Baba, S., et al. : IEEE Trans. Nucl. Sci., NS-40, 56 62 (1993).

(41) Doty, F. P., et al. : Nucl. Instrum. Methods. Phys. Res., A353, 356 360 (1994).

(42) Redus, R. et al.: To be published in Nucl. Instrum. Methods, 1996.

\title{
IV.次世代の放射線スペクトロスコピー
}

\author{
新日本製鐵塗 倉門 雅彦, 京都大学 大澤 大輔, 片野 林太郎, \\ 伊藤 真, 五十棲 泰人, 理化学研究所 清水 裕彦, \\ 神戸大学 戎 健男, 東京情報大学 渡辺 正
}

\section{1. 超伝導トンネル接合素子による X 線検出}

エネルギー分解能の優れた放射線検出器として半導体検 出器が広く用いられているが, そのエネルギー分解能は信 号電荷量の統計的摇らぎ $(5.9 \mathrm{keV}$ の放射線に対して 100 $\mathrm{eV}$ 程度)によってほとんど決定されてしまっており，現状 からの大幅な向上は期待できない。

半導体の場合, 放射線によって励起された電子から放出 されるフォノンは，他の電子をエネルギーギャップの上に 励起するのには役立たない。一方，超伝導体ではエネル ギーギャップ(超伝導電子対を壊して 2 個の電子を励起す るのに必要な最小エネルギー)が $1 \mathrm{meV}$ 程度と小さいため に, フォノンによってあ電子が効率よく励起される。その 結果, 半導体の場合の数 1,000 倍もの電子が励起され, 励 起電子数の統計的摇らぎの割合は半尊体の場合の数 $1 / 10$ となる。超伝導トンネル接合では励起電子を信号電荷とし て取り出せるので, 検出素子として利用できる(1)。超伝導 転移温度が比較的高い NbやTaなどの超伝導体を用いた

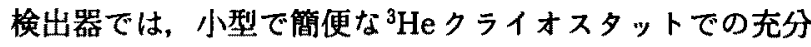
な冷却が可能である。

\section{(1) 单接合素子}

第 IV-1 図に, 面積が $0.178 \times 0.178 \mathrm{~mm}^{2}$ の Nb/Al$\mathrm{AlO}_{x} / \mathrm{Al} / \mathrm{Nb}$ 接合の (a) 構造と (b) ${ }^{55} \mathrm{Fe}$ からのX線 $(5.9 \mathrm{keV}$ ， $6.5 \mathrm{keV}) に よ る$ 波高スベクトルを示す。スペクトルは， 信号の前置增幅器出力を $2 \mu \mathrm{s}$ という短い時定数で波形整形 して得られた。 $5.9 \mathrm{keV}-\mathrm{X}$ 線に対して, 半導体検出器より 優れた $88 \mathrm{eV}$ という分解能が得られている(2)。前置增幅器 を改良することにより，これとほぼ同じ特性の素子で73 $\mathrm{eV}$ という分解能む達成されている(3)。

ローレンスリバモア国立研では，面積が $0.1 \times 0.1 \mathrm{~mm}^{2}$ 程度の接合 $\left(\mathrm{Nb} / \mathrm{Al} / \mathrm{AlO}_{x} / \mathrm{Al} / \mathrm{Nb}\right)$ を用いて, $5.9 \mathrm{keV} の \mathrm{X}$ 線に対して $36 \mathrm{eV}$ という，超伝導体放射線検出器としての これまでの最高分解能を達成している。この素子では， $\mathrm{Nb}$ と $\mathrm{Al}$ の各首の厚みが約 $200 \mathrm{~nm}$ であり, $\mathrm{Nb}$ 中で生成さ れた励起電子をエネルギーギャップの小さいAl首に集め てから信号電荷としている(4)。炭素の $\mathrm{K}_{a}-\mathrm{X}$ 線 $(277 \mathrm{eV}) \mathrm{k}$ 対しては $12.6 \mathrm{eV}$ という優れた分解能が得られている(5)。

\section{(2) 直列接合素子}

1 つの超伝導トンネル接合で放射線を直接検出する単接 合素子では，接合面積 $S$ が小さい，薄膜素子であるため に吸収効率が低い，エネルギーの高い放射線の検出が困 

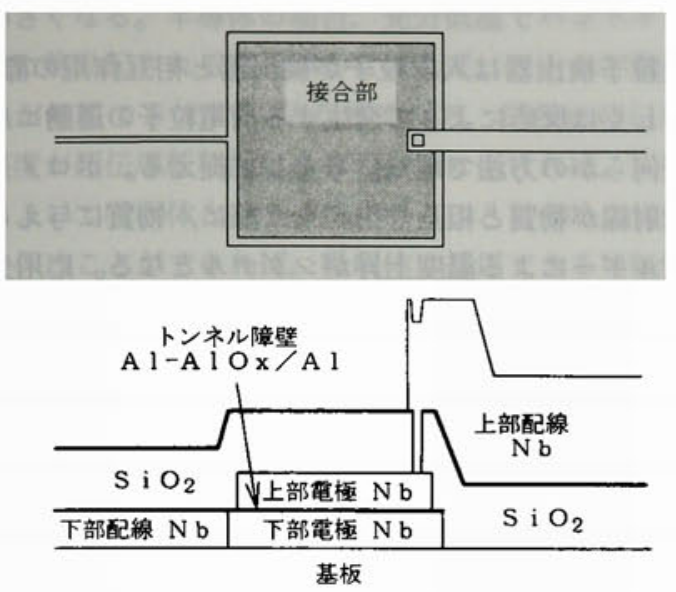

(a) 構 造例

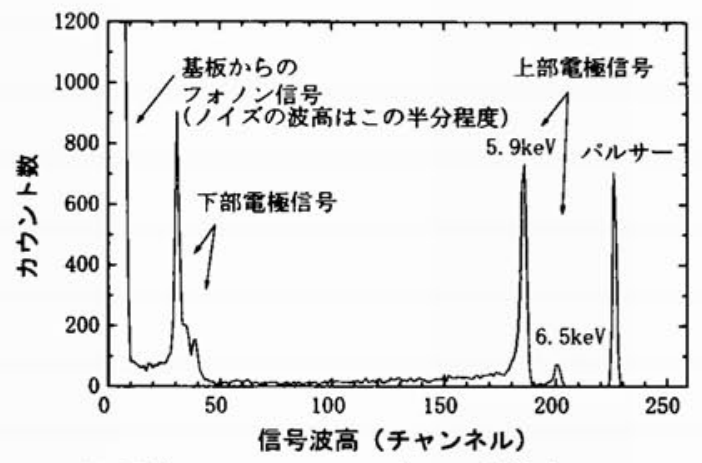

(b) 面積 $0.178 \times 0.178 \mathrm{~mm}^{2}$ の $\mathrm{Nb}$ 系接合での 波高スペクトル

第 IV-1 図 単接合検出器素子の構造例と ${ }^{55} \mathrm{Fe}$ からの X線 $(5.9$ と $6.5 \mathrm{keV})$ の測定スペクトル

難、などの欠点がある。Sを小さくせざるを得ないのは, 単接合素子では素子の静電容量が $S$ に比例して大きくなっ てしまうためである。基板上に多数の接合を直列に接続し て, フォノンセンサーとして利用する直列接合素子では, 基板で放射線を吸収してそのエネルギーをフォノンに变換 すればよく，また直列接合では実効静電容量 $\propto S^{1 / 2}$ とでき るために, 実効膜厚と検出器面積を大きくすることが可能 である ${ }^{(6)}$ 。

しかしながら, 直列接合素子ではフォノンの基板から外 部への散逸があるために，信号の波高が放射線の入射位置 によって異なってしまう(6)。その入射位置依存性を低減す るためには，第 IV-2 図(a)に示すような素子中心には直列 接合を配置しない構造とし，接合総面積 $S$ を大きくすれば よい(2)。しかし， $S$ をあまり大きくすると，実効静電容量 が大きくなるために，ノイスの影響が大きくなってしま う(2)。ノイスを充分小さく抑えられるSであると同時に, 信号波高の入射位置依存性による分解能劣化を抑制できる 必要がある。

第 IV-2 図(b)に構造を示した素子の基板裹面の 3 ヶ所に $\alpha$ 粒子を照射し，中心接合と直列接合加信号を取り出し て波高の相関を調べた結果を第 IV-3 図に示す。 $\alpha$ 粒子入

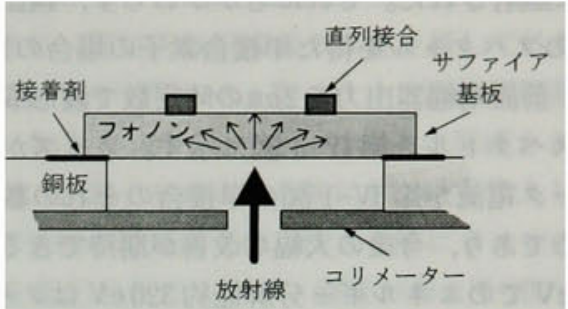

(a) $\alpha$ 粒子測定のためのセットアップ例

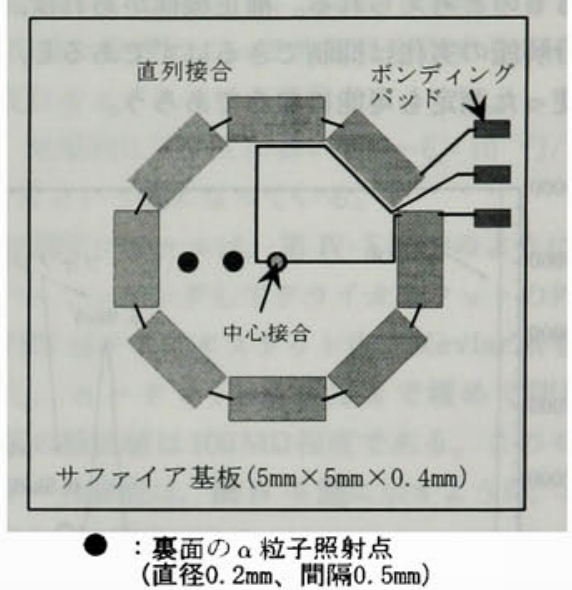

(b) 中心接合を設けた直列接合検出器 （值径 $200 \mu \mathrm{m}$ 接合 $\times 3$ 並列 $\times 32$ 直列 + 直径 $150 \mu \mathrm{m}$ 中心接合）

第IV-2 図 フォノン拡散方式直列接合検出素子

射位置が素子中心から離れるに従って中心接合信号が小さ くなっている。直径 $0.2 \mathrm{~mm}$ のそれぞれの照射点の内部で あ中心接合之直列接合からの信号の大きさが 1 対 1 に対応 していることから， $0.05 \mathrm{~mm}$ 以下の入射位置分解能が可 能である。また, その入射位置分解能を利用すれば, 直列 接合信号の大きさの入射位置依存性を補正できる。

外周が $2.16 \times 2.16 \mathrm{~mm}$, 内周が $1.2 \times 1.2 \mathrm{~mm}$ の直列接 合で ${ }^{55} \mathrm{Fe}$ からの X 線が検出できている。直列接合は直径 $0.2 \mathrm{~mm}$ の円形接合を 56 個直列に接続したものである。こ の素子には波高の入射位置依存性補正機構はないため, X 線はコリメータを通して素子中心の直径約 $0.25 \mathrm{~mm}$ の狭

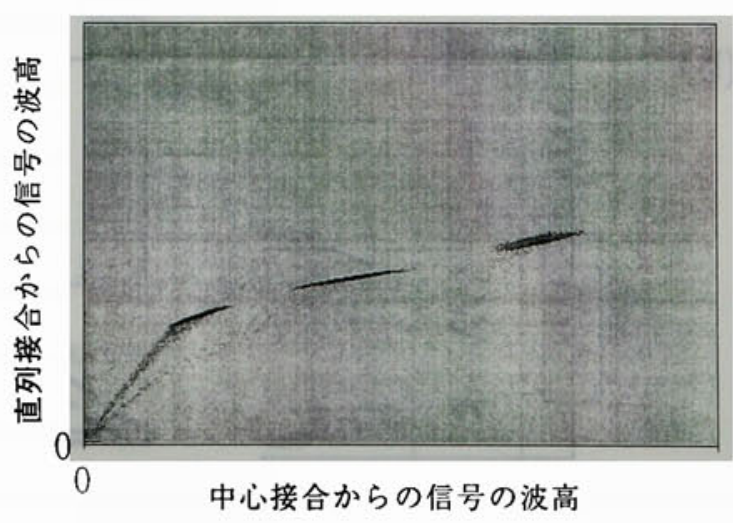

第 IV-3 図 $\alpha$ 粒子に対する第 IV-2図(b)の素子での中心接合 と直列接合からの信号の波高の相関 
い領域に照射された。そ㧈にあかかわらず，検出効率は第 $\mathrm{N}-1$ 図のスペクトルを得た単接合素子の場合の100倍程度 之高い。前置增幅器出力を $2 \mu \mathrm{s}$ の時定数で波形成形して得 られたスペクトルを第 IV-4 图に示す。ノイズが大きいの は, リーク電流が第 $\mathrm{IV}-1$ 図の単接合のそれの数10倍も大 きいためであり，今後の大幅な改善が期待できる。

$5.9 \mathrm{keV}$ でのエネルギー分解能約 $320 \mathrm{eV}$ はノイズの 190 $\mathrm{eV}$ より明らかに悪くなっているが，これは入射位置依存 性によるあのと考えられる。補正機構があれば，このエネ ルギー分解能の劣化は抑制できるはずであるし，より広い 領域を使った测定も可能になるであろう。

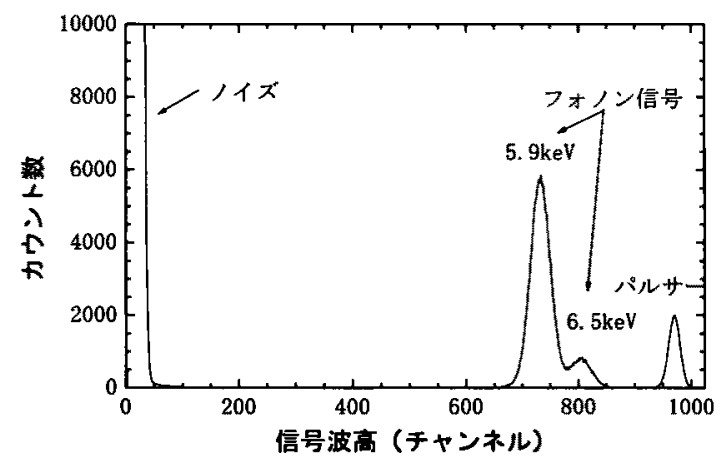

第 N-4 図 直列接合検出素子による ${ }^{55} \mathrm{Fe}$ からのX線(5.9上 $6.5 \mathrm{keV})$ の測定スペクトル

以上述へてきたように，超伝導トンネル接合は高分解能 で高計数率の測定も可能な検出器になり得る。直列接合で は，単接合に比べて検出効率が大幅に改善される。

（倉門雅彦, 大澱大輔, 片野林太郎, 伊藤 真, 五十棲泰人)

\section{2. ボロメータを利用した X 線·中性粒子検出}

中性粒子検出器は入射粒子が検出器之相互作用の際に, 散乱もしくは反応によって発生する荷電粒子の運動エネル ギーを何らかの方法で電気信号として捉える。ボロメータ は，放射線が物質と相互作用をした際に，物質に与えられ たエネルギーによる温度上昇がシグナルとなる。伈用分野

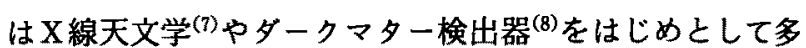
岐にわたる議論がある(9)。特にX 線応用では非分散型 X 線検出器として最高のエネルギー分解能 $(5.9 \mathrm{keV}$ に対し $て 7 \mathrm{eV})$ を実現しており，単結晶を用いた分散型分光器に あう一息というところまで来ている。

ボロメータでは，第 IV-5 図(a)に示すように，吸収体で 発生した熱量を温度計で測定する。放射線がエネルギーE を放出した場合に生じる温度变化は $\Delta T=(E / C(T)) e^{-t / \tau}$ で与えられる。ただし， $C(T)$ は温度 $T$ における熱容量, $t$

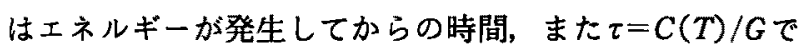
$G$ は吸収体，温度計と低温熱浴との間の熱伝導率である。 ボロメータが内在的に持つエネルギー分解能は半值幅で $2.35 \xi \sqrt{k_{B} T^{2} C(T)}$ と与えられ, 入射エネルギーE, 熱伝 導率 $G$ に侤存しない( $k_{B}$ はボルッマン定数, $\xi$ は実際の検 出器の構成で決まる補正係数で半導体で構成した場合およ そ $\xi=1.5 \sim 2.0$ 程度)。したがってェネルギー分解能を向 上させるためには，熱容量を小さくしてできるだけ低温に 保つことが本質的となる。実際の温度範囲は数 $100 \mathrm{mK}$ 加 ら数 $10 \mathrm{mK}$ 程度で, ${ }^{3} \mathrm{He}$ の減圧, 希釈冷凍, 断熱消磁等の方 法によって冷却する必要がある。

導体では伝導電子が熱的な性質を支配しており $C(T) \propto$ $T$ という温度依存性を示すが，絶縁体では格子振動が主で (a)

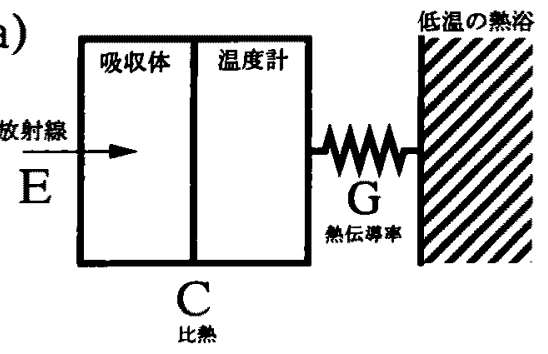

(b)

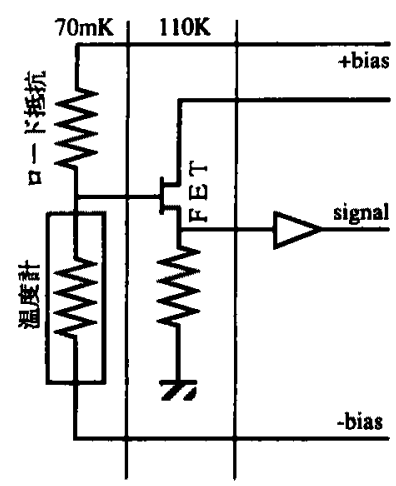

(c)

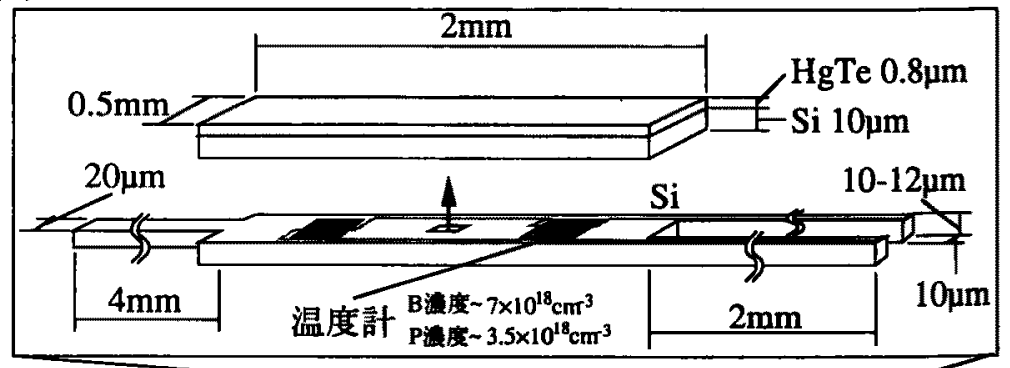

第 N-5 图 ボロメータの (a) 熱的な構造, (b) 読み出し回路の模式图および

(c)ロケット奏験用のX線ボロメータ素子 
低温の極限で $C(T) \propto T^{3}$ のように温度とともに比熱は急激 に小さくなる。半導体の場合, 充分低温でバンドギャップ の上に熱励起される電子が少なければ，ほとんど電子系の 比熱が無視できて $T^{3}$ の依存性を持ち，同様に超伝導体て も温度が超伝導転移温度よりも充分に低ければ，同様の理 由によって吸収体として使用できることになる。比熱を小 さく保っことができれば，吸収体に採用できる可能性があ るため物質としての選択の幅は極めて広く, 半導体検出器 やガス検出器とは際立って違う特徴がある。なお熱伝導率

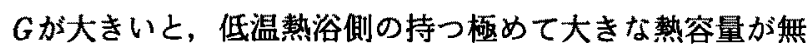
視できず測定器としては適さないので, 熱的な構造は注意 梁く設計しなければならない。

$\mathrm{X}$ 線天文学では，主に $\mathrm{keV}$ 領域の X 線が観測対象とさ れ，鉄の特性 X 線は特に重要な意味を持つ。ボロメータ によるX線の一光子分光は，1984年にWisconsin 大学之 NASAによって初めて実証された(10)。その後改良が重ね られ，現在は2000年打ち上げ予定の日本の X 線天文衛星 ASTRO-E搭載に向けて実用器か開発中であり, その前哨 戦ともいえるロケット実験が間むなく行われる。以下では 主にロケット実験に使用されているボロメータについて説 明老行うことにする(7)。

ボロメータの具体的な構造を第 IV-5 図(c)に示す。この 素子の設計動作は $70 \mathrm{mK}$ で，鉄ミョウバンを用いた断熱 消磁型のクライオスタットで领却する。検出器は 36 個のピ クセルで構成され，ピクセルの大きさは $2 \times 0.5 \mathrm{~mm}$ で, 互い違いに対向して配置され 2 列に並べられていて，おの おの 3 本の細い足で基板に接続されている。ピクセル上に
はイオン注入によって $400 \times 200 \mu \mathrm{m}$ の大きさの温度計が作 り込んであり,電気的な配線は 2 本足を通して外部に結線 されている。素子は単一のp型シリコン両面研磨基板から 製作され，細足はdry plasma etching で形成される。1 オン注入は，B原子を注入した後にP 原子を注入して半数 を補償して目的の濃度にする。注入の際にイオンの入射エ ネルギーを変化させて，イオン濃度がおよそ $200 \mathrm{~nm}$ と推 定される厚みの中でほぼ一様に分布するようにする。吸収 体を直接温度計の上に作ると, 温度計に到達するフォノン 量が入射 X線の位置によって大きく变化する。そこで吸 収体と温度計をエポキシで点接着することによってこれを 回避する。結果的に $70 \mathrm{mK} に お い て C \sim 6 \times 10^{-14} \mathrm{~J} / \mathrm{K}, G \sim 7$ $\times 10^{-12} \mathrm{~W} / \mathrm{K}$ という值になっている。

温度計の電圧シグナルは, 第 IV-5 図(b)のように, FET を用いてバッファリングしてクライオスタットの外部で増 幅する。FETはクライオスタット内でKevlar系を使って 宙吊りにし，ヒータで $110 \mathrm{~K}$ 程度まで暖めて使用する。 ロード抵抗の抵抗值は $100 \mathrm{M} \Omega$ 程度である。このモデルで のエネルギー分解能は, 第 IV-6 图に示すように, $5.9 \mathrm{keV}$ に対して約 $14 \mathrm{eV}$ 程度である。

X線天文学では，対象天体の空間的な分布はとても重要 な意味を持つので，素子を 2 次元的に配列して撮像能力を 持たせることが強く望まれる。ボロメータでは, 冷却能力 と放射線による発熱の微妙なバランスの下にシグナルを取 り出すということが本質的であるため, 熱的構造が必然的 に複雑となる。この点はこれからの開発で重要な課題とな る。

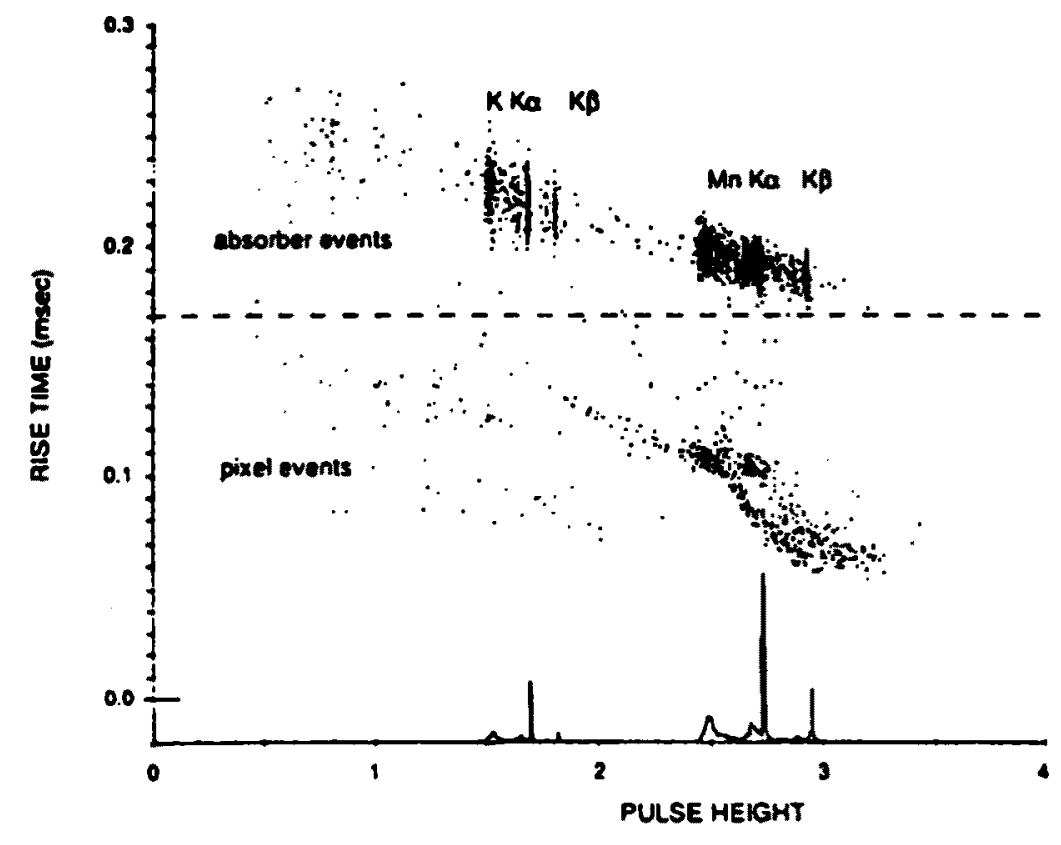

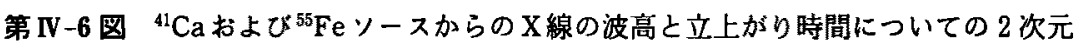
プロトおよび波高スベクトル

$\mathrm{X}$ 線が温度計が作り込んである基板で吸収された場合(図中点線よりも 下)には，X線が吸収体で吸収された場合(図中点線よりも上)に比べてフォ ノンが温度計に到達するまでの時間が短いために, 両者のパルスの立上が り時間に明確な差異が認められる(文献(7)より抜粋)。 
放射光実験などへ応用する場合，最大計数率を含む時間 的な特性が問題之なる。現在のマイクロカロリメータでは パルス減衰の時定数はおよそ $10 \mathrm{~ms} ゙$ でり, $10 \mathrm{~Hz}$ 以上の 計数率で入射すると，吸収された熱量がすべて放出される 前に，次の放射線が入射することになってしまい，エネル ギー分解能が悪くなる。この点を克服する物としてNIS型 の超伝導素子をボロメータの温度計に利用するという研究 あ始められている(11)。このような方法によってボロメー 夕の応用範囲は放射光計測にあ広がり，沉用の精密分光素 子としての応用が期待されている。

（清水裕彦）

\section{3. 準安定超伝導粒子(SSG)を利用した 中性粒子検出}

素粒子的宇宙物理学においては，暗黑物質，太陽二之一 トリノ、モノポールなどの検出が焦眉のこととなっており, 従来の型にはまらない新しい原理に基づいた梌出器の開発 が行われている。新しい検出器では $1 \sim 1,000 \mathrm{eV}$ 領域のエ ネルギーの測定が念頭におかれている。このような低エネ ルギーの領域 (<1 keV)では, 検出部を横切る粒子によっ て失われるエネルギーを温度上昇として観湘する手段がと られることが多い。希釉冷東機温度 (数 $10 \mathrm{mK}$ )では熱容量 が非常に小さくなるので，小さいエネルギー損失でも超伝 導現象やボロメー夕的方法で十分測定しうる信号になる。

\section{（1）準安定超伝尊粒子(SSG)による検出の原理}

SSG(Superheated Superconducting Granules)は，検 出の原理は極めて単純である。第 1 種超伝導体はsuperheated (Hsh), supercooled(Hsc)の 2 つの性質があり(第 N-7 図)，Hsh と Hsc との間の領域で微粒子は準安定状態 にある。準安定超伝導相にある金属粒子に外部から適当な 刺激を与えると, 非可逆的に常伝導相へ移行する。その過 程としては「磁気的」,「熱的」の 2 つが可能である。磁気的 過程はモノポールの検出に使える。以下では熱的過程だけ を取り上げる。

金属微粒子内の原子亡入射粒子との相互作用が金属粒子 の温度変化を引き起こし, 微粒子は超伝導状態加ら常伝導 状態へ相転移する。相転移に伴うマイスナー効果の消失に よる磁束変化をピックアップコイルで検出する。典型的な 転移時間は直径数 $10 \mu \mathrm{m}$ の微粒子の場合，数 $10 \mathrm{~ns}$ である。

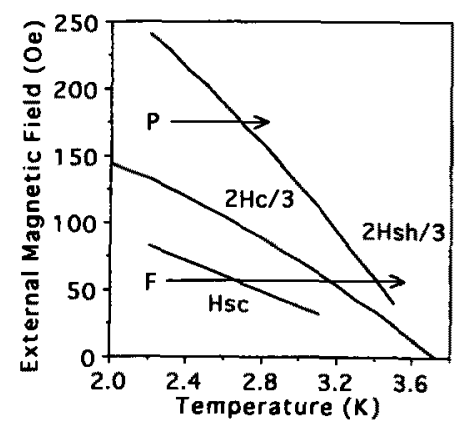

第 N-7図 直径 $20 \mu \mathrm{m}$ の Zn 粒子の温度·磁場相図
微粒子自体は入射粒子に対する標的であると同時に検出器 であある。微粒子の相転移に必要な蓄積エネルギーは微粒 子の物質, 大きさ, 動作温度, 外部磁場等によって決まる。

動作点をPに設定した場合，蓄皘エネルギーが設定され たエネルギー值以上ならば相転移を起こし，それを信号之 してとらえ得る。すなわち設定エネルギーが $5 \mathrm{keV}$ なら ば, $10 \mathrm{keV} て ゙ も 50 \mathrm{keV}$ であ同じ大きさの信号が得られる。 動作点を $\mathrm{F} に$ 設定した場合には，蓄皘されたエネルギーの 大きさを直接测定することが可能となり、フリップ・フ ロップ機構と呼ばれている。動作点がHscより低い相図内 に置かれているとき，充分なェネルギーの蓄積によって， 粒は加熱され準安定状態になり，そして2Hsh/3を超えた ときに常伝導状態へフリップする。相転移後, 粒は周辺の 物質に熱を放出し自らは冷える。粒が初めの動作温度まで 冷却されHsc以下になると超伝導状態にフロップする。粒 のフリップとフロップそれぞれの信号の間の経過時間が, 粒に蓄積されたエネルギーの目安を与える。

\section{（2）現状と将来の展望}

$\alpha$ 線, $\gamma$ 線, 中性子線に対する準安定超伝導粒子の応答は 確認されている。フリップ・フップ現象に関しては，実 験的検証は行われたが，その実用化にはまだ時間を要す る。暗黒物質の検出を目指して，標的質量 $1 \mathrm{~kg}$ を越える 検出器が組み上げられ，長期間の観測が行われようとして いる。

暗黒物質の捕捉に向けて，ボロメータ方式が標的重量の 点で一歩進んでいる。現在のエネルギー感度は数 $\mathrm{keV}$ 程 度であり，さらに感度を上げるために標的を細分化するこ とが要求されている。一方，SSGはもとも之微粒子で, 現在 $30 \mu \mathrm{m}$ 径で数 $\mathrm{keV}$ の感度が得られている。感度は体積 で利くので，例えば直径を $5 \mu \mathrm{m}$ にすれば数 $10 \mathrm{eV}$ の感度に なる。

SSG 検出器の開発は依然として初期の段階にある。低 エネルギーニュートリノはともかく，暗黒物質の検出が近 い将来達成されるかどうかは今のところ明らかではない。 しかしながら，微粒子の超伝導状態での特徽や放射線照射 下でのそれらの振舞いについて, 理解が着実に進んでい る。

他の低温検出器と比べて，SSG は幾つかの利点を有し ている。第 1 種超伝導物質の多椂性は種々の応用に際して 柔軟に対応できる。例えば暗黑物質(スピン依存，スピン非 (依存), 太陽ニュートリノ, 二重 $\beta$ 崩壊，太陽アクシォン検 出なざに対応できる。宇宙線,コンプトン散乱, 放射性物質 などによるバックグラゥンドについては，たった 1 個の粒 のフリップを引き起こすニュートリノや暗黒物質などの稀 反応と多数の粒のフリップを引き起こす荷電粒子反応とを 識別する能力によって堿少させることができる。小さい寸 法の粒のフリップ時間はナノ秒の程度であるので, 早い夕 イミング情報はSSGから得られる。 
SSG 粒子検出器の実用化は微粒子製造, 寸法選別, 信号 読出し等に関する開発に大きく依存している。中性子弾性 散乱による核の反跳のエネルギー検出はSSGの重要な課 題であったが, 実験的にも検出が確立されたし, フリップ ・フロップの原理確認むなされたので, SSG 検出器の開発 あ一層進展していくと考えられる。（戎 健男, 渡辺 正）

\section{一参考文献一}

(1) Kurakado, M. : Nucl. Instrum. Methods, 196, 275 (1982), A314, 252 (1992) ; Radioisotopes, 43, 354 (1994), [in Japanese].

(2) Kurakado, M., et al. : Proc. SPIE, 1743, 351 (1992).

(3) Kisimoto, M., et al. : Nucl. Instrum. Methods, A370, 126 (1996).

(4) Mears, C. A., et al. : J. Low Temp. Phys., 93, 561 (1993).
(5) Labov, S. E., et al. : IEEE. Trans. Appl. Super., 5, 3034 (1995).

(6) Kurakado, M., et al. : Rev. Sci. Instrum., 62, 156 (1991).

(7) Stahle, C. K., et al. : Nucl. Instrum. Methods, Phys. Res., A370, 173, (1996):

McCammon, D., et al. : ibid., A370, 266 (1996).

(8) 倉門雅彦, 㝨輪 复 : 物理誌, 51 [6], 425 (1996); Ootani, W., et al. : Nucl. Instrum. Methods, Phys. Res., A372, 534 (1996).

(9) Nucl. Instrum. Methods, Phys. Res., A372, (1996).

(10) McCammon, D., et al. : J. Appl. Phys., 56, 1263 (1984).

(11) Nahum, M., Martnis, J. M. : Appl. Phys. Lett., 66, 3203 (1995).

(12) Proc. 6th Int. Workshop on Low Temperature Detectors, Nucl. Instrum. Methods, A370, No.1, (1996).

\section{V．放射線センシングと先端技術の融合}

\section{1. 最近の光電子増倍管と半導体光電素子}

\section{(1) メタルパッケージ PMT}

光電子增倍管 (photomultiplier tube : PMT) は, 応答 速度が速いことや微弱光検出ができること等の優れた特性 を持っため, 分光分析や放射線計測, 医療機器等の幅広い 分野で使用されている。最近は様々な分野で測定装置の小 型化が進められており, PMTにも同様に小型化が強く望 まれるようになった。従来のPMTでは, 使用されている ガラス容器や電極の形状の制約によって, 小型化が困難で あった。この要求を実現するため, 半導体光電素子で広く 使用されている，TO-8タイプの金属パッケージをPMT に利用することが検討され，新しい薄型電極と共にメタル パッケージPMTが開発された。

メタルパッケージPMTは, コンピュータシミュレー ションによる電子軌道設計と, 最新の微細加工技術を駆使 して作られた新しい薄型電極(メタルチャンネルタタイノー ド)を, メタルパッケージ内に有するPMTである。メ夕 ルチャンネルタイノードは, 小さなラインフォーカス型ダ イノード群のアレイのような構造で,一つのダイノードの 厚さは $1 \mathrm{~mm}$ 以下と非常に薄い。直径 $15 \mathrm{~mm}$, 高さ $10 \mathrm{~mm}$ のメタルパッケージを利用した超小型の R5600U シリース と, $28 \times 28 \times 20 \mathrm{~mm}$ の角形のメタルパッケージを使用し たR5900U シリーズとがある。両者の外観形状を第 V-1 図に示す。

(a) R5600U シリーズ

R5600U の断面図を第 V-2 図に示す。メタルチャンネ ルタイノードが 8 段組み込まれていて, 電流堌倍率は $3 \times$ $10^{5}$, 有効径は $8 \mathrm{~mm}$ 。各ダイノードが近接に配置されてい
浜松ホトニクス吉沢 祐二, 日本原子力研究所 片桐 政樹, 名古屋大学 井口 哲夫

るため, 時間応答性が非常に速く, 立ち上がり時間(rise time)が $650 \mathrm{ps}$, 走行時間の拡がり (TTS)が $280 \mathrm{ps}$ と, 従来 型の最む速いPMT と同等の特性を有している。また，他 の特長の一つは磁界に対して鈍感なこと。近接構造のため に電極間の電解強度が強いこと,メタルパッケージが磁気

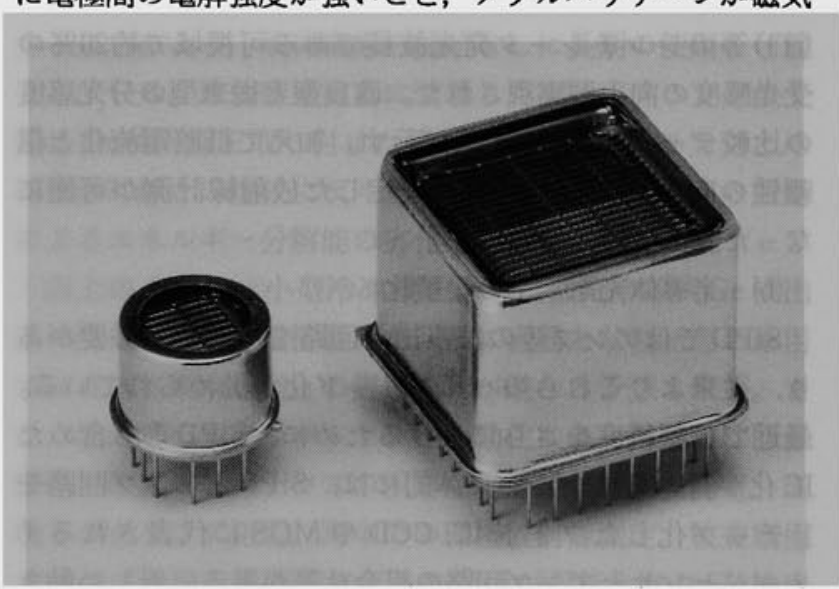

第 V-1 図 メタルパッケージPMT の外観写真

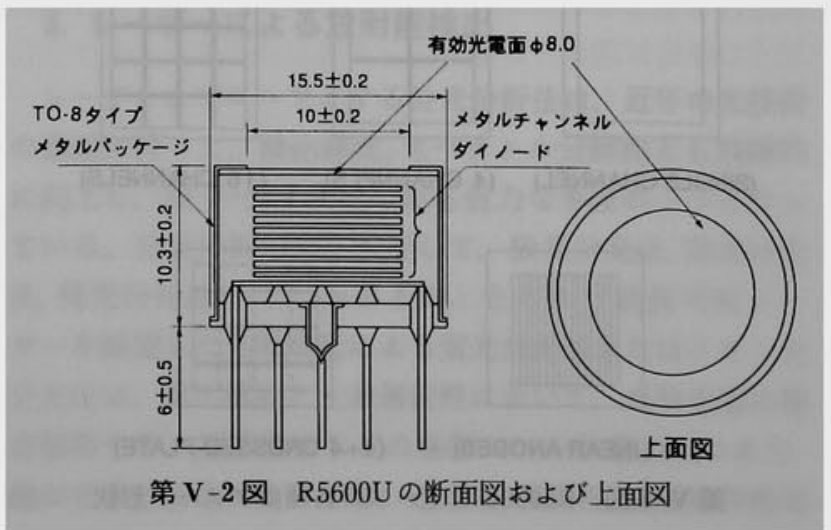


シールドケースとして働くことが, その理由として挙げら れる。このR5600Uシリーズは, 放射線計测装置等のポー タブル化一一役担うことが期待される。

(b) R5900 シリーズ

基本的な特長は R5600シリーズと同様だが，電流増倍率 は $2 \times 10^{6}$, 有効面積は $18 \times 18 \mathrm{~mm}$ と大きい。メタルチャ ンネルダイノードは，その増倍過程で隣接ダイノード群へ の電子の漏れが非常に少ない。この特長を利用して, クロ ストークの小さなマルチアノードPMTを作ることができ るため，R5900シリーズでは，4 チャンネルや16チャンネ ル等の 5 種類のアノード形状が用意されている。これらの アノード形状図を第 V-3 図に示す。測定装置の小型化の みならず，シンチレーションファイバやシンチレータブ ロックと組み合わせた放射線位置検出への応用が期待され る。

\section{(2) 半導体光電素子}

シリコンフォトダイオード(SiPD)に代表される半導体 光電素子は，広い波長域で感度が高いことやコンパクトな こと，安価なこと等のため，工業計測や分析装置，民生用 受光素子等に幅広く使用されている。また, Si PDは, 光 計測だけでなく，X線や荷電粒子の直接検出も可能である ことが知られている。最近では市場の要求に応じ, 高感度 化，高信頼性化，高機能化や集積化が進められている。

(a) 受光感度の向上

S3590-08 に代表される SiPD は, 従来品と比べて CsI (TI)等のシンチレータ発光波長である可視域で約 $20 \%$ の 受光感度の向上が害現された。改良型と従来型の分光感度 の比較データを第 V-4 図に示す。加えて低暗電流化と信 頼性の向上により,さらに安定した放射線計測が可能に なった。

\section{(b) 半導体光電素子の集積化}

SiPDではアンプ等の読み出し回路を用意する必要があ り，従来よりこれらのハイブリッド化が進められている。 最近では集積度をさらに上げるために，SiPD等る含めた IC化が行われている。具体的には，SiPDとアンプ回路を 1 チップ化したフォトIC, CCDやMOSに代表されるイ メージャンサとアンプ回路の組合せ等がある。新しい動き

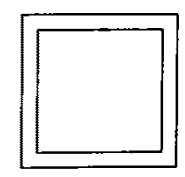

(SINGLE CHANNEL)

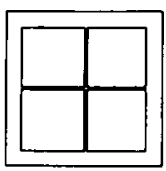

(4 CHANNELS)

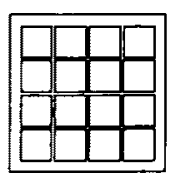

( 16 CHANNELS)

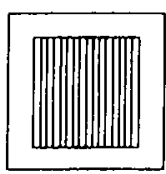

(16 UNEAR ANODES)

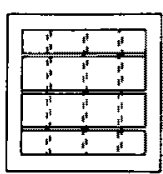

(4 + 4 CROSSEO-PLATE)

第 V-3 - R5900Uシリーズの各種のアノード形状

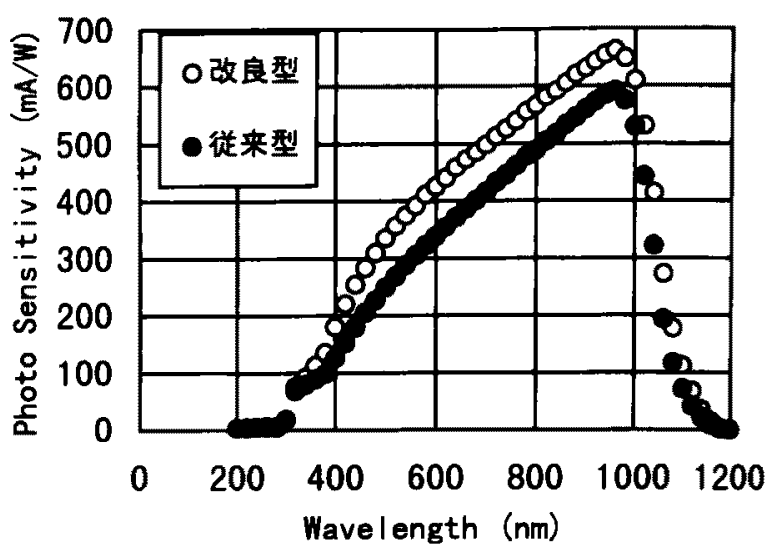

第 V-4 图 SiPDの従来型と改良型の分光感度比較

として, SiPD レイと, IC 化したC-MOS読み出し回路 を 2 チップで組み合わせ, 使い方の自由度を向上させた応 用例あある。また，CsI(T1)シンチレータと組み合わせた モジュールす用意され，ユーザーに使いやすい形で製品が 提供されるようになった。

（吉沢咗二）

\section{2. 小型冷凍機を用いた電気冷却式 Ge検出器}

$\mathrm{Ge}$ 検出器はて線スペクトロスコピーを行う上で不可欠 な検出器であるが，使用にあたって液体窒素で冷却する必 要があり，その維持管理に手間を必要としかつ入手が困難 な場所では用いることができない。また，液体窒素容器を 必要とするため小型化も困難である。このため, 液体㗌素 を用いずにメインテナンスフリーで使用できる Ge検出器 の開発が様々な分野から要望され研究が進められてきた。

10年ほど前加らクローズドサイクル He冷涷機を冷却に 用いた電気冷却式 Ge 検出器が開発され市販されている。 しかし，冷却部において発生する振動によるエネルギー分 解能の劣化を防ぐ振動吸収機構を必要とし，かつその損失 分を含めて冷却能力を確保するため, 大型で重量のある圧 縮機が使用される(1)。このため, 装置自体の小型·僌量化 が困難であり可搬性に難点があった。

最近, 液体窒素を用いずに電源を供給するだけで使用で きる小型冷凍機を用いた電気冷却式 $\mathrm{Ge}$ 検出器が国内外で 開発された。本検出器は, 従来の液体堂素冷却型 $\mathrm{Ge}$ 検出 器とほぼ同等のエネルギー分解能を有しており，汃小型 なため簡単に持ち運びできる。

米国ローレンスリバモア研究所のグループは，サンクー ラという商品名の小型冷凍機を用いた小型電気冷却式 Ge 検出器を開発した(2)。検出器本体の大きさは, 直径 16 $\mathrm{cm}$, 長さ $60 \mathrm{~cm}$ であり，相対効率 $40 \%$ の Ge 検出素子を約 $10 \mathrm{~h}$ で冷却可能としている。エネルギー分解能は 1.33 $\mathrm{MeV} r$ 線に対して $2.0 \mathrm{keV}$ の性能を有している。冷凍機の 振動による影響を防止し性能を確保するために，冷倲機の 冷却駆動部の後部にバランサを付けて, かつ加速度センサ からの信号をむとにこの駆動部をアクティブに駆動してい 
る。このような冷却機構を用いることにより機械的振動の 発生を防止し, エネルギー分解能を従来の液体窒素冷却と ほぼ同等とすることに成功している。当初の開発目的は in-situで核查察を行うための検出機器の検出部としての 使用を考えている。

一方, 国内では Ge検出素子の冷却に小型スタリーング 冷凍機を用いた電気冷却式 $\mathrm{Ge}$ 検出器の開発研究が原研を 主体としたグループにより進められており, 用途に合わせ て 3 種類の検出器が開発された。

原子炬施設内の配管・機器等の内部に存在する放射能あ るいは環境放射能等のin-situ 測定などを主目的に開発さ れた超小型電気冷却式 Ge 検出器の構造を第 V-5 図に示 す(3)。サイズが $12 \times 12 \times 35 \mathrm{~cm}$ であり, 重さは約 $5 \mathrm{~kg}$ であ る。 $14 \mathrm{~cm}^{3} \mathrm{Ge}$ 検出素子(相対検出効率：1\%) を冷却するた めに, 直径 $6.5 \mathrm{~cm}$, 長さ $11 \mathrm{~cm}$ の小型のスタリーング冷凍 機(住友重機械工業製SRS-2110: 冷却能力 $1 \mathrm{~W}$ ) 1 台を用 いている。本冷凍機は, 交流 $50 \mathrm{~Hz}$ 電源を圧縮器両端の電 磁石に供給し, 内部のピストンを往復運動させて得られた 圧縮 $\mathrm{He}$ を冷却駆動部に導き往復運動させることにより冷 却を行う。

$\mathrm{Ge}$ 検出器の冷却に本冷凍機を用いた場合, 機械的振動 により発生する信号ノイズをいかに除去し, エネルギー分 解能の劣化を防止するかが最大の実用化の課題である。こ の点については, ピストンのサイクリックな往復運動によ り発生するマイクロフォニック雑音が $10 \mathrm{kHz}$ 以下の周波 数となるため, 前置増幅器の初段回路の振動防止およびス ペクトロスコピアンプの最適な波形整形時定数の選択など によりエネルギー分解能の劣化を防いでいる。また, 冷却 後冷凍機に供給する駆動電源の電圧を低減し機械的振動を 低減する方法や駆動電源のサイン波をパルス的に駆動し機 械的振動を低減する方法を併用することにより，エネル ギー分解能を液体窒素冷却型とほぼ同等まで低減してい る。開発された小型電気冷却式検出器は $90 \mathrm{~min}$ で冷却さ $れ 1.33 \mathrm{MeV} \gamma$ 線に対して $2.5 \mathrm{keV}$ のエネルギー分解能が 得られている。

一方, 小型スターリング令凍機の冷却能力が小さいた め, 1 台の使用では相対検出効率が $3 \sim 4 \%$ の Ge 検出素 子の冷却が限界となる。このため, 現在液体窒素冷却型で

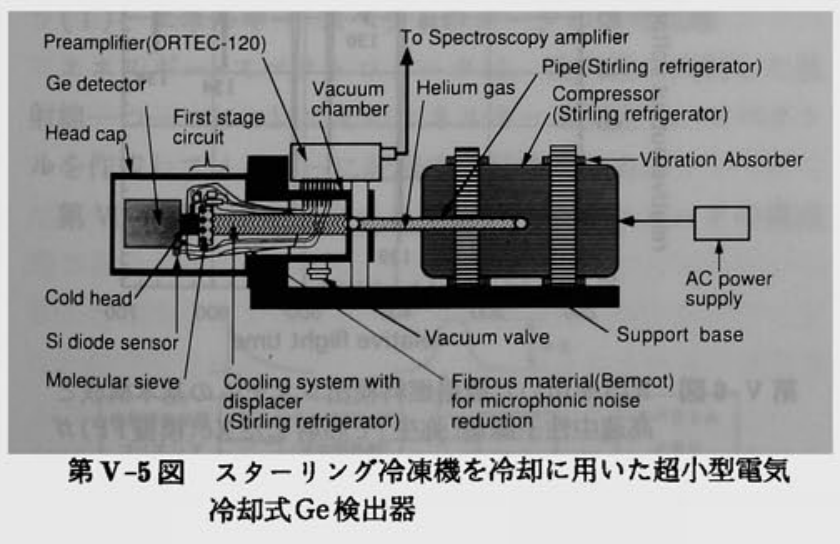

主流となっている相対検出効率10３0\%の大きさの検出素 子を泠却可能とした沉用型電気冷却式 $G e$ 検出器が開発さ れた (4)。冷却に 2 台のスターリング令凍機を用い, 冷却部 先端に逆Y字型の接続治具を取り付けてその中央に $\mathrm{Ge}$ 検 出素子を装着した構造であり, 大きさは $14 \times 14 \times 60 \mathrm{~cm}$ で ある。 $85 \mathrm{~cm}^{3} \mathrm{Ge}$ 検出素子(相対効率14\%) を約 $6 \mathrm{~h}$ で冷却で きる。冷凍機を駆動した場合と停止した場合について, ス ペクトロスコピィアンプの波形整形時定数を変化させてエ ネルギー分解能を測定した結果, $0.5 \sim 4 \mu \mathrm{s}$ の時定数の变 化に対して両者はほぼ同じ特性を示しており, マイクロ フォニック雑音の影響をほとんど受けていないことが判明 している。1.33 MeV $\gamma$ 線に対して $2.06 \mathrm{keV}$ のネルギー 分解能が得られている。本汎用型検出器は相対検出効率 $30 \%$ のe検出素子まで冷却できることが確認され，市販 化されている。

さらに, 原子炉や加速器等を用いた測定環境での $\mathrm{Ge}$ 検 出器の放射線損傷に対応して, 検出素子を交換可能な PopTop型電気冷却式Ge検出器が開発された ${ }^{(5)}$ 。ORTEC 社で開発したPopTop·Ge検出キャプセルを 2 台のスター リング冷涷機で冷却している。相対検出効率 $17 \% \mathrm{Ge}$ 検出 素子を約 $8 \mathrm{~h}$ で冷却し, $1.33 \mathrm{MeV} \gamma$ 線に対して $2.2 \mathrm{keV}$ の エネルギー分解能を得ている。

冷凍機を用いた別方式として, 液体窒素蒸発防止型 $\mathrm{Ge}$ 検出器が開発された ${ }^{(6)}$ 。本方式では, 既存の液体窒素冷却 型 $\mathrm{Ge}$ 検出器から蒸発してくる窒素を泠涷機により再液化 することにより, 液体窒素の補給なしに長期の使用を可能 としている。液体窒素容器に装着した密閉用フランジの上 部に $\mathrm{Ge}$ 検出器を取り付けた構造とし, このフランジと冷 倲機冷却部との接続にゲル状物質を用いることにより振動 によるエネルギー分解能の劣化を防止している。

以上のように, 小型冷倲機を用いた電気冷却式 $G e$ 検出 器の開発により, 維持管理が非常に容易となり一部の応用 では液体窒素冷却型との置き換えが進むと予想される。ま た, 加えて小型化やバッテリー駆動化により, 例えば原子 灲内でのメインテナンスの困難な場所での放射能測定, 環 境モニタリング測定, 海中での環境放射能測定, 核査察用 ポータブル検出機器等などへの使用が可能となり Ge検出 器の適用範囲がさらに広がると考えられる。（片桐政樹）

\section{3. レーザーによる放射能検出}

レーザーをプローブとする分光分析法は，近年の光技術 の進展に伴って, 検出感度, スペクトル分解能とも飛躍的 に向上し, 原子.分子検出の最も有力な手段の一つとなっ ている。分光分析には, 大別して, 吸光分光法, 蛍光分光 法, 発光分光法の 3 つがあるが, とりわけ波長可変レー ザーを駆使した共鳴励起による蛍光分光法またはイオン化 分光法は, 検出感度と元素選択性において, 光検出器の雜 音限界や単一原子検出などの極限レベルに達しつつあり, 他の元素分析法に比へてても, 迅速性, 汎用性, 遠隔操作性等

Vol. 38, No. 9 (1996) 
の観点から, 放射性同位元素 (RI) 分析に対して, 多くの 有利かつ魅力的な点を持っている。そこで, 本稿では, ウ ラン等のレーザー同位体分離技術の基本原理でもあるレー ザー共鳴イオン化分光法 (Resonance Ionization Spectroscopy : RIS) に焦点を絞り, 極微量 RI の超高感度/高 選択検出技術としての現状と将来展望について概説する。

まず, RIS の原理は, 単一または複数の波長可変レー ザーを用いて, 対象の原子·分子のエネルギー準位に相当 する波長の光子ビームを生成·照射し，それらを共鳴的に 選択励起することから始まる。これら励起準位の原子・分 子は，緩和過程によって基底準位に遷移するが，このとき 放出される蛍光強度を測定するのが蛍光分光法であるのに 対し, RISでは, さらにレーザービームまたはパルス電場 を印加して電離させ, 発生した電子またはイオンを検出・ 定量するすのである。このように, 対象原子·分子の固有 のエネルギー準位に応じて, 段階的に励起・イオン化する ことにより, 本質的に高感度・高選択(または, 高 $S / N$ 比) 性が生まれ, 原子蒸気化できる任意の物質に適用可という 沉用性, レーザーパルス幅で決まる高速分析性のほか, 質 量分析計と組み合わせることで, 従来の熱イオン化質量分 析で問題となる同重体の干渉を回避した同位体分析が行え るなどの特長を有している(7)。

世界初の RIS 実験は, 1971年に V. S. Letokhov ら(露) により行われ, ルビーレーザー励起色素レーザーを用い て, 基底状態の $\mathrm{Rb}$ 原子の 2 段階イオン化 $(795 \mathrm{~nm}$ と 347 $\mathrm{nm})$ が実証された ${ }^{(8)}$ 。続く $2 \sim 3$ 年の間に, 基底状態の $\mathrm{Na}, \mathrm{U}, \mathrm{Cs}$ 原子および準安定状態の $\mathrm{He}$ および Ca 原子につ いて，パルスおよび連続発振色素レーザーを用いたRIS実 験が相次いで報告されたが，1975年，G. S. Hurst(米)ら が, 準安定 He 原子につき, 効率100\%のイオン化を達 成 ${ }^{(9)}$,さらに, 1977 年にCs の単一原子検出に成功した ${ }^{(10)}$ ことに及んで, RISが超高感度元素分析に極めて有力な手 段であると認知されるに至った。このように，RIS技術の 開発研究の歴史は, 現時点で 20 年程度に過ぎないが,この 間の技術進展や応用分野の拡大状況は, 1982年から 2 年ご とに開催されている(1996年度で 8 回目)「共鳴イオン化分 光法とその応用 (Resonance Ionization Spectroscopy and Its Applications) 探際シンポジゥムのプロシーディ ングによく反映されている。放射線センシング，あるいは 原子力技術に関連のあるトピックスとしては，下記のよう なあのが挙げられるであろう(11)(12)。

\section{(1) 核物理研究}

高エネルギーイオン加速器を用いて, $\mathrm{Fe}, \mathrm{Ag}, \mathrm{Sn}, \mathrm{Pt}, \mathrm{Au}$, $\mathrm{Hg}$ 等のターゲットとの核反応で生成される希少·短寿命 核種の核スピン, 磁気/四重極モーメント等の核特性パラ メー夕の測定に, オンラインRISが積極的に活用されてい る。また，わが国におけるユニークな核物理実験として, ${ }^{136} \mathrm{Xe}$ の二重 $\beta$ 崩壊娘核種検出 (KEK), $500 \mathrm{MeV}$ で生成され た熱化ミューオニウム検出(東大理・中間子研), 準安定反陽
子 He 原子の観測(東大核研) (13)等に RIS が適用されてい る。

\section{（2）環境試料分析}

地球物理・天文学における年代測定の観点から, $\mathrm{Kr}, \mathrm{Xe}$ などの希ガスや ${ }^{10} \mathrm{Be},{ }^{26} \mathrm{Al},{ }^{36} \mathrm{Cl},{ }^{97,98} \mathrm{Tc}$ 等の長半減期核種の 極めて小さい同位体組成比の測定, また核実験やチェル， フイリリ原発事故で環境中に放出された ${ }^{90} \mathrm{Sr},{ }^{239} \mathrm{Pu}$ などの極 微量人工RIの定量にRISが活躍している。ちなみに, 検 出可能な最小原子数は, 試料の調整に工夫がいるものの, 気体試料で $10^{2}$ 個, 固体試料で $10^{7}$ 個と見積 るられ, 放射能測定, あるいは加速器質量分析等に比べても, 析違 いの超高感度化が実現されている。このほか, 環境有害物 質である $\mathrm{Hg}, \mathrm{Pb}, \mathrm{NO}_{x} / \mathrm{SO}_{x}$, ダイオキシン等の高感度モニ タリングや固体表面(半導体薄膜, 高融点金属, セラミック ス)からのイオンスパッタリング中性粒子の分析等にも RISが応用されている。

\section{（3）同位体分離技術}

RISは, もともとU, Th等の核燃料物質のレーザー濃縮 技術における副産物とあいえなくないが，さらに Gdや $\mathrm{Sm}$ などの可燃毒元素などの同位体分離基礎過程の研究へ の展開もみられる。また, ここ $2 \sim 3$ 年来, $\mathrm{Am}, \mathrm{Cm}, \mathrm{Bk}$, Cfなどの超ウラン元素群について, 10 12 原子程度の極微 量試料をあとに, イオン化ポテシャルなどの化学的特性の 測定がRISによって行われている。

以上のように, RISは, 極低レベル核変換物質の超高感 度/高選択的検出を可能とすることから，これまで放射線 測定をべースにして行われてきた核計装, 照射線量評価, 個

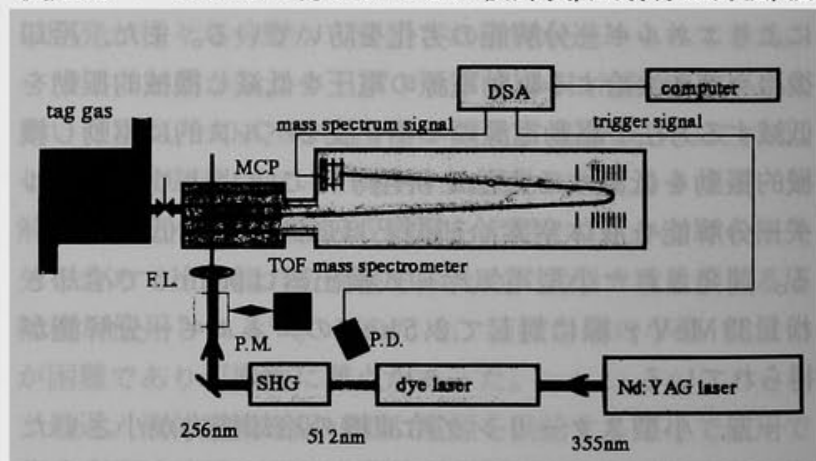

異スベクトルダ影

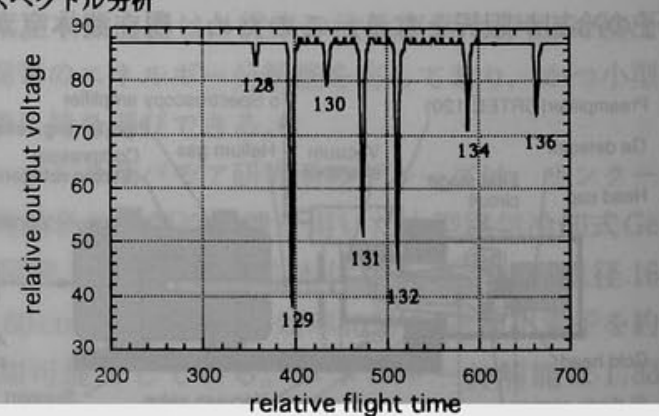

第 V-6 図 RISを用いた破損然料検出システムの基本構成と 高速中性子源炉「弥生」で照射した Xe(模擬 FP)ガ スの高感度検出および同位体組成比(質量スペク トル)分析実験列 
人被曝管理, 環境放射線モニタリング等の分野の技術革新 につながることが期待される。具体例の 1 つして，東大 工·原子力工学研究施設では，RISを用いた新しい破損燃 料検出システムの開発が進められている。第 V-6 図に, 基本的なシステム構成と実際に高速中性子源炬「弥生」で照 射したXe(模擬核分裂生成物)ガスの高感度検出扰よび同 位体組成比の分析実験結果(質量スペクトル)を示すが, 従 来法に比べて, 感度, $S / N$ 比, 迅速検出などの要求性能を 十分満たすと同時に，同位体組成比の識別による破損然料 の位置決めに優れた特性を有することが見い出されてい る(14)。しかしながら，放射線計測システムの代替を目指 して, RISの工学応用を推進するためには，高性能かつ高 信頼度の固体波長可変レーザー光源の開発(ダイオード レーザーや光パラメトリック発振技術等の利用), 原子蒸気 化プロセスの簡便化,システム全体のコンパクト化抒よび 低コスト化等の技術課題を克服する必要があると考えられ る。

（井口哲夫）

\section{一参考文献一}

(1) Sakai, E., et al. : IEEE Trans. Nucl. Sci., NS-29 [1], 760 (1982).

(2) Buckley, W. M., et al. : UCRL-JC-119679, (1995).

(3) Katagiri, M., et al. : KEK Proc. 94-7, Radiation Detector and Their Uses, 174 (1994).

(4) Katagiri. M., et al. : KEK Proc. 95-1, Radiation Detector and Their Uses, 219 (1994).

(5) Katagiri, M., et al.: To be published in KEK Proc. Radiation Detector and Their Uses.

（6）小林広幸, 他：原子力学会「1993秋の大会」予稿集，F51.

(7) Chen, C. H., et al. : "Lasers and Mass Spectrometry", (Lumbman, D. M., ed.), Oxford Univ. Press, 3 (1990).

(8) Ambartzumian, R. V., et al. : JETP Lett., 13, 217 (1971).

(9) Hurst, G. S., et al. : Phys. Rev. Lett., 35, 82 (1975).

(10) Hurst, G. S., et al. : Appl. Phys. Lett., 30, 229 (1977).

(11) Kluge, H. J., et al., ed. : Proc. 7th Int. Symp. on Resonance Ionization Spectroscopy. Bernkastel-Kues, Germany, 1994 (1995).

(12) Parks. J. E., et al., ed. : Abstract 8th Int. Symp. on Resonance Ionization Spectroscopy, State College, USA, 1996 (1996).

(13) 山崎敏光, 他: 東大核研所内報, No.268, p.1 (1993).

(14) 佐藤 泰, 他：原子力学会「1996秋の大会」予稿集（II）, B 60, p.275.

\section{VI. 放射線センシングに高速ディジタル処理技術を生かす}

搠東芝 小野寺 徹, 東京大学 高橋 浩之

\section{1. アナログ回路からReal time信号処理回路へ}

放射線検出器が出力するパルス波形そのるのをディジタ ル時系列データに変換できる高速なADC(Analog to Digital Converter)が開発されたことにより，アナログ回路 では実現不可能な種々のディジタル信号処理手法を放射線 センシングに適用できるようになった。

ディシタル信号処理をリアルタイム化することにより， 従来装置の課題であった高計数率測定におけるスループッ ト(入力計数率に対して実際に計数される計数率)の大幅な 改善が期待できる。

本節では, リアルタイム・ディジタル信号処理をGe検出 器を用いた $\gamma$ 線エネルギー・スペクトロメータに適用し, 分解能やスループットの改善を実現した例を紹介する。

(1) エネルギー・スペクトロメータの信号処理

エネルギー・スペクトロメータは, 検出器に入射した放 射線一つ一つについてそのエネルギーを測定し，スペクト ルを作成してメモリーに記録する装置である。

第 V-1 図に従来のアナログ式スペクトロメータの構成

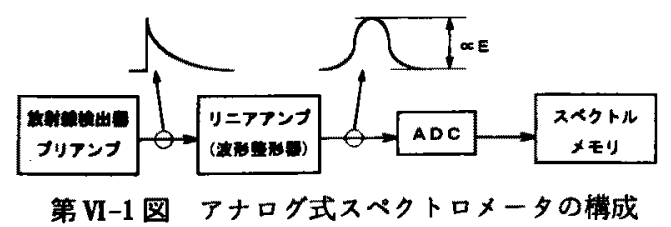

を示す。検出器に放射線が入射すると、プリアンプから $100 \mu \mathrm{s}$ 程度の時定数で指数関数状に減衰するパルスが発生 する。このパルスをリニアアンプで波形整形し，検出器に 入射した放射線のエネルギーに比例する波高值を有するパ ルスに変換する。この波高值をADCを用いてディジタル 値に変換して頻度分布を作成することによりスペクトルを 得る。

スペクトロメータの性能は, リニアアンプに内蔵する波 形整形方式により決定され，これまで様々な方法が試みら れてきた。現在では, 波形整形方式の評価手法が確立され ており ${ }^{(1)}$, 三角波に整形する三角波形整形が最す性能が良 いとされている。

しかし，アナログ素子を用いて三角波形を実現するのが 困難であるため, 市販のリニアアンプにはガウス関数状に 整形するガウシアン波形整形またはガウシアン波形整形回 路を土夫して三角形に近づけた疑似三角波形整形が採用さ れている。

（2）アナログ信号のディジタル化

第 VI-2 図に試作したディジタル・スペクトロメータの構

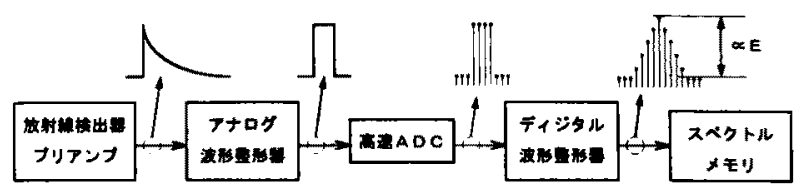

第VI-2図 ディジル・スペクトロメータの構成

Vol. 38, No. 9 (1996) 
成を示す。アナログ式スペクトロメータとの違いは, 最初 に高速 ADC を用いてプリアンプの出力信号波形をディジ タル時系列データに变換するところにある。一だんディジ タル值に変換してしまえば, その後の処理に数値演算を適 用して，アナログ素子の組合せでは実現できない三角波形 整形を実現するというのが基本的な考え方である。

しかし，実際に入手し得るADCの変換精度やディジタ ル演算素子の処理能力を考慮すると, プリアンプの出力信 号をそのままディジタル化する方法では, 信号処理が複雑 になりすぎてりアルタイム姏理を実現するのが困難であ る。そこで，第 VI-2 図に示すように，高速ADCの前段に プリアンプの出力信号波形を矩形波状のパルスに変換する アナログ波形整形回路を使用した。

プリアンプの出力信号波形を直接 AD変換する場合, 最 低です100MSPS(sample per sec)の変換速度を有する高 速 ADCが必要となるが，この方式によりパルスの頂上部 の変化が少なくなるので, 25MSPS程度の ADCが使用可 能となる。また，100MSPSを超える変換速度では8-BIT 精度程度のADCしか入手できないが，25MSPSでは12 -BIT精度の ADCが入手可能であるため，精度の高いディ ジタル時系列データの取得が可能になる。さらに, 変換速 度を落とすことにより, 高速なディジタル演算素子を使用 する必要あなくなり，汎用のプログラマブル素子を用いる ことができる。

(3) ティジタル処理のリアルタイム化

(1)式にディジタル・フィルタの基本的な演算内容を示 す。

$$
Y_{j}=\sum_{i=0}^{N-1}\left(A_{i} \times x_{i}\right)
$$

ここで， $N$ は500個程度のサンプル数， $x_{i}$ は高速 ADCに より変換された時系列データ，係数 $A_{i}$ は個々の時系列 データに対する重みである。時系列データ $Y_{j}$ が三角波と なるよう $A_{i}$ を適当な值に設定することにより，三角波形 整形を実見する。

しかし，(1)式をそのままディジタル演算回路に置き換 えた場合，メモリーアクセス回数および演算回数が多く， 現在入手し得る高速な演算素子を使用してすりアルタイム といえるだけの高速性は実現できない。

ところで， $x_{i}$ は高速 $\mathrm{ADC}$ の前段に設けたアナログ波形 整形により矩形波に変換されているので, 係数 $A_{i}=1$ の きに $Y_{j}$ が三角波となる。したがって，(1)式は(2)式に 示す単純な移動平均の式に変換することができる。

$$
Y_{i}=\sum_{i=0}^{N-1} x_{i}=x_{0}+Y_{j-1}-x_{N}
$$

この結果, 前回の演算結果 $Y_{j-1}$ に対して 2 回の加娍算 を行うだけで，サンプル数に依存せずに時系列データ $Y_{j}$ を更新することができるようになる。試作回路では $160 \mathrm{~ns}$ ごとに時系列データ $Y_{j}$ の值を更新しながら、エネルギー 情埌を抽出している。

\section{（4）ティジタル・スペクトロメータの性能}

第 VI-1 表に従来方式(ガウシアン波形整形) 試作した ディジタル方式の分解能, ピーキング・タイム $T_{p}$ (入力信 号の立上がりから出力にピークが生じるまでの時間)およ びデッド・タイム $T_{d}$ (入力信号の立上がりから出力信号が ベースラインに十分に減衰するまでの時間)を示す。

ディジタル方式では, 従来方式の半分のピーキング・タ イムで, 同等の分解能が得られている。したがって, ディ ジタル信号処理のノイズ除去能力が優れているということ ができる。また，デッドタイムは従来方式の 1/4 程度とな り，高計数率測定に招けるスループットが著しく改善され る。

\begin{tabular}{cccc}
\multicolumn{5}{c}{ 第 VI-1 表 } & 性能 比較 \\
\hline 波形整形器 & $\begin{array}{c}\text { 分解能 } \\
1.33 \mathrm{MeV}{ }^{60} \mathrm{Co}\end{array}$ & $T_{p}$ & $T_{d}$ \\
\hline ガウシアン波形整形器 & $1.77 \mathrm{keV}$ & $13.3 \mu \mathrm{s}$ & $53.2 \mu \mathrm{s}$ \\
ディジタル波形整形器 & $1.73 \mathrm{keV}$ & $6.4 \mu \mathrm{s}$ & $12.8 \mu \mathrm{s}$ \\
\hline
\end{tabular}

\section{(5) まとめ}

ディジタル好理の対象をエネルギー情報の抽出に絞り， いくつかの最適化を施した結果として, 分解能特性やス ループット特性が改善されることを確認することができ た。しかし、ディジタル化本来の利点は, 一たんディジタ ル時系列データとして記録されたデータであれば，数值演 算処理手法を用いて様々な情報抽出に利用可能なところに ある。

将来, DSP(Digital Signal Processor)のようなディジ タル演算素子の処理速度が改善されれば、ディジタル处理 の利点を活加した汎用の高機能放射線計測装置が実用化さ れると期待される。

（小野寺 徽）

\section{2. ディジタル信号処理による高機能 放射線センシング}

放射線センシングは，放射線自体を直接測定するのでは なく，その電離作用や，物質中での発光，発熱，放射線の入 射に伴うなんらかの痕跡を測定するという方法によってい る(2)。したがって，この放射線と物質の相互作用をいかに 上手に利用するかが，放射線センシングに拈ける性能を決 定することになる。ところが，同一種類の放射線の場合で あ，相互作用の種類は 1 つには限らない上に，放射線のエ ネルギーによりそれらの各相互作用の確率・比率が大きく 変化する上に，椱合過程す生じる。放射線センサに求めら れるさまざまな特性一検出効率, エネルギー・時間分解能, 信号対雑音比など一はすべて個々の基本的な相互作用に依 存しているため, 放射線センサーの応答は多くの場合に大 変複雑なすのとなる ${ }^{(2)}$ 。

一方，このような応答の複雑さは，個々のシステムによ り程度の差はあるが, 当然, センサーから得られる信号に も現れている。そこで，熟練した湘定者と同様に注意深く 
観察することのできる信号好理回路があれば，実際にセン サー内でどのような事象が生じたかを検知し，それに応じ た信号の取扱いを施すことで，本来の放射線そのものの测 定という観点からは不完全あるいは不要な情報を分離・抑 制したり，適切に補正を加えたりすることで，測定対象の 放射線に関する，より正確な情報が得られるのではないか との考えが生まれてくる。そのような信号の取扱いを，ア ナログ回路により行うことは不可能とはいえないが，回路 の規模や安定性などの点で困難である。そのため，詳細な 信号の観察をディジタル方式により行い、より多くの情報 を取り出そうとすることが最近試みられるようになってき $た^{(3) \sim(13)}$ 。

具体的な方法としては，高速 ADC を利用することで, 放射線センサーから得られる数 ns〜数 $10 \mu \mathrm{s}$ の幅の信号パ ルスの波形を離散数值データとして取り込み，その結果， 得られた信号波形データに対して個々の信号パルスごとに 適切な演算処理を施すというものである。離散数值データ に対しては計算機処理が可能なので, 従来のアナログ回路 ベースのシステムでは考えられなかったような高度に非線 形な信号処理が寒現される。このような信号好理を，本稿 ではディジタル波形処理と呼ぶこととする。

ディシタル波形処理については本来, 個々の放射線セン サーの種類や対象放射線の種類やエネルギーに応じて，さ まざまな信号処理法が考えられる。すなわち、ここでの信 号処理は各センシングごとに対応するンフトウェアであ り，放射線センサーの種類や測定対象が変化するごとに異 なるンフトウェアを走らせることになろう。東大の中沢研 究室ではこのようなアイデアに基づいて，新しい放射線信 号処理アルゴリズムを模索している(3)〜(8)。本節では, 以 下に示すような 3 つの例について，著者らのアプローチを 中心にどの程度のことができているのかを紹介し，今後の 展望につなげることとしたい。なお、ディシタル值を用い ることに特有の微分直線性などの問題 ${ }^{(8)}$ については, 前 節を参照していただきたい。

詳細な信号波形解析の必要な例としては，NE213シン チレータの波形弁別が有名であるが，最新の高速 ADCを 用いて波形デー夕を取得すれば，ソフトウェア処理によ り，面倒な設定を必要とせず，高い弁別能を得ることがで きるあのと期待される。最近普及しつつおる計測用のバス であるVXIbus上に高速ADCモジュールの波形ディジタ イザ(5GS/s)とシステムコントローラおよび信号処理用の コンピュータ・イーサネットインタフェースなどを実装し たシステムを用いた場合，使用可能な計数率は $100 \mathrm{cps}$ 程 度であるが, NE213 と光電子増倍管の組合せから得られ る信号も波形ディジタザに直接入力し，詳細に解析する ことが可能である。

CdTeおよびCdZnTe 検出器は, 別項で示されているよ うに, 常温の半導体検出器として, 最近注目を浴びつつあ る(14)。しかしこれらの検出器では， $\varepsilon$ 值自体はCdTeの
常温の值で $4.4 \mathrm{eV}$ 程度と $\mathrm{Ge}$ と比べてもそう覀くはない が, 正孔の mobility が小さいため, 電荷収集の際に正孔 が長い距離を移動すると波高分布が低エネルギー側にシフ トし, エネルギー分解能が大きく劣化するという問題が あった。この場合，電極形状が定まれば信号波形と正孔の 移動距離の間の関係が求められるので，それを用いて波高 値の補正をすることが可能である(9)。立ち上がり時間を用 いた補正用のアナログ回路では, 比較的単純な線形関係に 帰着させて, 補正を行い, 線形にならない部分は测定デー 夕を捨てる方式によっているが(15)(16), ディジタル方式で は，相当複雑な庆答であっても，あらかじめ波形と収集効 率の間の関係が与えられていれば，亡゙のような形状の検出 器に対しても適用可能である。また, 最近注目されている Lukeの方法など, 検出器の電極形状を工夫して正孔の成 分を減少させる万法とも併用が可能であると思われる。

名大グループでは, 上記の $\mathrm{CdTe}$ 検出器の問題に関し て, ニューラルネットワークを適用したリアルタイムの ディジタル波形処理を行っている ${ }^{(10)}$ ほか，放射線検出器 の実際の使用時における問題の一つとして, マイクロフォ ニック雑音の問題を取り扱っている(11)。マイクロフォ ニック雑音は通常，機械的な振動によるものなので，放射 線の信号パルスのような数 $\mu \mathrm{s}$ 程度の短い時間領域ではそ の性質は大きくは変化しないむのと考えられる。そこで信 号パルスが到来する直前の時間までの雑音の周波数成分を FFTなどにより調べておき，その成分を取り除くような 処理を施すことにより影響を小さく抑えることが可能であ る。この場合, FFTをいちいち行うのでは大変であるの で, 適応フィルタを用い, 時間領域において同様の処理を 施すことす可能である(12)。

同軸型 HPGe 検出器の信号波形については, 信号電荷の 生成場所に応じてその形状が大きく変化することが知られ ているが, この場合，その信号波形の変化を利用すること は, あまり考えられていなかった。種々の雑音の存在下 で, どの程度の情報をこの信号波形から引き出せるかにつ いては，実際にセンサーを動作させて実験を行ってみるま では，少なからず疑問の残るところであろう。しかし，波 形の立ち上がり部分の形状を波形の積分値 $A$ 之波形の最 高值の $10 \%$ か $90 \%$ の 2 点を結んだ直線の下の台形の面積 $B$ を用いて計算されるパラメータ $R a=A / B$ と立ち上がり 時間の 2 種類のバラメータを用いて信号を解釈することを 行ってみると, 信号パルスは意外に多くのいろいろな情報 を含んでいることがわかる(4)(5)。

電極形状により求められた信号波形のモデルを用いる

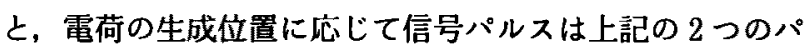
ラメータ平面上である関係に従うように分布しなくてはな らないが，実際に ${ }^{60} \mathrm{Co}$ の 線を湘定してみると，第 V-3 図に示すように，複雑な形状を示す広い範囲に分布する。 ここで, 各点は、それぞれ 1 個のパルス波形に対応する。 これを算に雑音の影響で広がっているとすると考えてしま 
うことは簡単であるが，ここでは，あう少し詳しく調べて みる。光電効果を起こす確率の高い低エネルギーの $\gamma$ 線を 同軸部分の真横から照射をして測定を行ってみると, 第 V-4図のように，ほぼモデルに従う分布が得られる。先 ほど述べた雑音の影響は, ここで得られた分布の幅に相当 するものと考えられる。

さらに，同軸型のクローズドェンド部分にのみ照射を 行ってみると，第 VI-5 図のように，さらに下の部分の分 布が得られる(この部分の波形については，最近シミュ レーションなども行われている(13))。これで, 第 VI-3 図 の主要な分布についての説明はついたが，残りの部分につ いては，どうであろうか。低ェネルギーの 場合の雑音よりは，エネルギーが高い分だけ波高が高くな り,したがってS/N比も高くなるので, 分布はシャ一プ になるはずであるが，测定結果では逆に広がった部分が観 察される。EGS4シミュレーションコードとセンサー波形 そデルを用いて信号パルスのシミュレーションを行ってみ ると,この部分は 1 回あるいは複数回のコンプトン散乱お よび光電効果の組合せにより, 電荷がセンサ内の複数の場 可にほぼ同時に生じたような事象に関する信号パルスであ

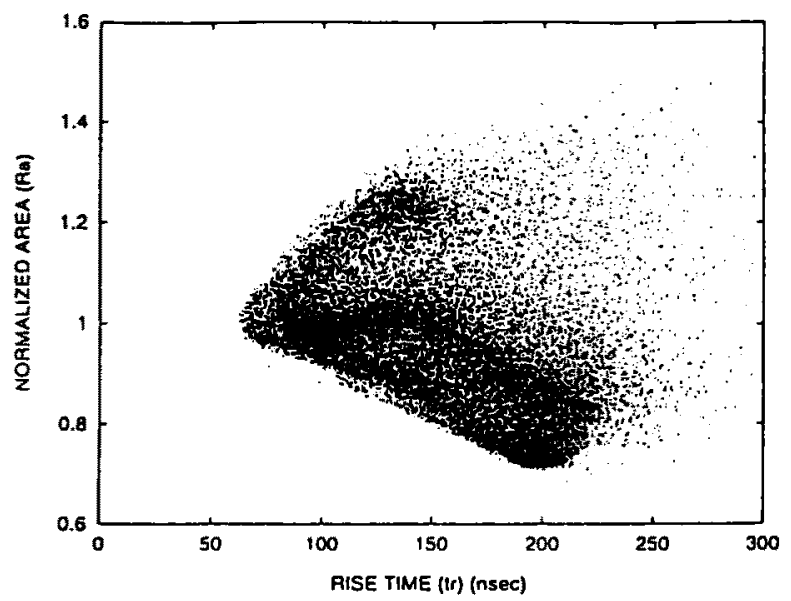

第 VI-3 図 ${ }^{60} \mathrm{Co} の \gamma$ 線を照射して得られた信号のパラ メー夕表示

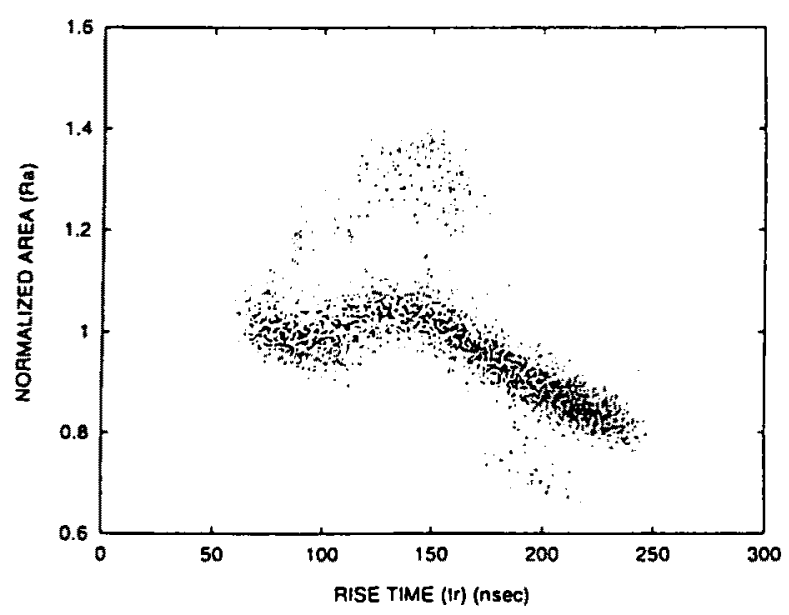

第 VI-4 図 ${ }^{57} \mathrm{Co}$ \%線を同軸部分へ照射した場合

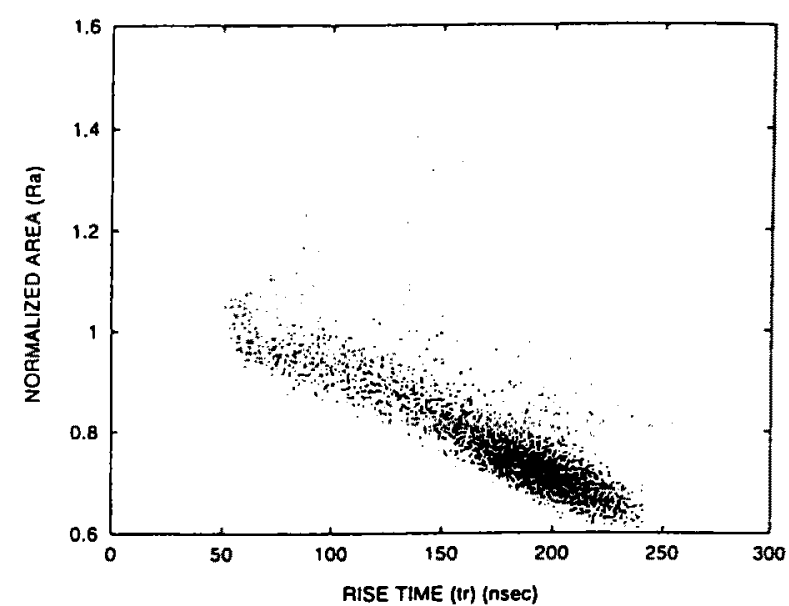

第 VI-5 図 ${ }^{57} \mathrm{Co} の \gamma$ 線をクローズドエンド部分へ照射した 場合

ることがわかる。さらに，立ち上がり時間の極端に遅いも のは，デトラッピングの生じたパルスであろうことも推测 される。

以上に示してきたように, 詳細にパルス波形を分析して みると、それらは複雑なセンサの応答に対応した複雑さを 示しているのである。実際の応用には，例えば，低エネル ギーの 線をセンサーの正面において湘定する場合には， クローズドエンド部分のみから得られる信号を選択的に測 定することで，バックグラウンド成分を減少させたり ${ }^{(5)}$, あるいは高エネルギーの $\gamma$ 線の測定では，センサー内で複 数回の反応を起こした成分のみを選択することで，ピーク ・コンプトン比を高めたりする(4)ようなことが考えられる。 しかし, 現時点で認められるそのような応用は, むしろ副 次的なものであり，本来，このような詳細な信号解析技術 が可能になってきたことそのものに注目されたい。すなわ ち, 次世代の放射線計測としては，このような信号解析技 術をごく当然な一つの要素技術として用いることを前提と して, 検出器の開発や, システム構築, デー夕処理, シミュ レーション計算などを総合して進めていくことが望ましい のではないであろうか。このような放射線センシングの新 しい展開を楽しみにしている次第である。

(高橋浩之)

\section{一参考文献一}

(1) Goulding, F. S., et al. : IEEE Trans. Nucl. Sci., NS-29 [3], (1982).

(2) Knoll, G. F.: "Radiation Measurements and Detection", John Wiley and Sons, 30 (1989).

(3) Takahashi, H., et al. : J. Nucl. Sci. Technol, 30 [1], 60 (1993).

(4) Takahashi, H., et al. : IEEE Trans. Nucl. Sci., NS-40 [4], 626 (1994).

(5) Takahashi, H., et al. : ibid., NS-41 [4], 1246 (1994).

(6) Takahashi, H., et al. : Nucl. Instrum. Methods., A353, 164 (1994).

（7）高橋浩之，他：ディジタル波形処理による放射線信号解析， 
放射線，19 [2]， 5 (1993).

(8) Takahashi, H., et al. : Nucl. Instrum Methods., A373, 119 (1996).

(9) Takahashi, H., et al. : To be published in Nucl. Instrum. Methods.

(10) Takenaka, Y., et al. : Nucl. Instrum. Methods., A369, 637 (1996).

(11) Uritani, A., et al. : ibid., A351, 598 (1994).
(12) Gatti, F., Nostro, A. : ibid., A368, 765 (1996).

(13) Kroll, Th., et al. : ibid., A371, 489 (1996).

(14) Schlesinger, T. E., James, R. B. : "Semiconductors for Room Temperature Nuclear Detector Applications", Academic Press, 292 (1995).

(15) Richter, M., Siffert, P. : Nucl. Instrum. Methods., A322, 529 (1992).

(16) Eisen, Y., Horovitz, Y. : ibid., A353, 69 (1994).

\section{VII. 放射線センシングと高度計算処理}

\section{1. シミュレーションコードの放射線計測} への利用

放射線輸送のシミュレーションコードは，実測では得る ことが困難か不可能な情報を与えることができる。すちろ んシミュレーションコードでは, 既知の物理現象しか考虑 できないし，基になっているデータの精度以上の精度で計 算することはできない。また，現実の複雑な放射線計測体 系をそのまま模擬することは簡単ではなく，様々な近似が 用いられている。このような限界を理解した上で，放射線 計湘分野にシミュレーションコードを応用することは，放 射線検出器の開発やその特性研究に有用である場合が多 W。

本節では，電磁カスケードモンテカルロ計算コード $\mathrm{EGS} 4^{(1)}$ の放射線計測分野への応用例を通じてシミュレー ションコードの有用性を紹介する。

\section{（1） $\tau$ 線検出器の底答解析の計算}

$\operatorname{NaI}(T 1)$ シンチレータなどの $\gamma$ 線検出器の単色 $\gamma$ 線に対 する応答関数の計算は, シミュレーションコードのもっと 6一般的な応用例である。波高分布からスペクトルを得る ためのアンフォールディングには, 応答関数が必要である が, 利用可能な単色 $r$ 線源が限られていることから, 必要 なすべてを実験的に求めることは難しい。RI線源で測定 した応答関数とシミュレーション結果を比較し, 計算の精 度を確認した上で, 各ェネルギーの応答関数を計算で求め ることが多い。Rogersは, $3 \times 3$ in.の Nal(T1)シンチレー 夕の $661 \mathrm{keV} \gamma$ 線に対する応答関数の実測值と計算值を比 較して $1.18 \mathrm{~g} / \mathrm{cm}^{2}$ の Be空が応答関数に影㸷を与える例を 示している(2)。一見, $661 \mathrm{keV} \gamma$ 線に対してこのような薄 いBeは影響がないように思えるが，実際の出力は 検出器および容器中で反応することにより発生した電子に より生じているためにこのようなことが起きる。

\section{（2）放射線検出器の検出効率の計算}

応答関数と同じような計算であるが, 放射線, 放射能モ ニタの検出効率の計算にもシミュレーションコードが使用 されている。放射性放出ガスのモニタとしては電離箱がよ く使用されるが, 出力からガス中の放射能濃度を得るには
高エネルギー物理学研究所 平山 英夫, 東北大学 岩崎 信

当該核種による電離効率が必要である。しかしながら，半 減期が短い核種の場合には奏測による測定は困難である。 鳥居らは，EGS4を用いて空気およびアルゴン電離箱の電 離効率を計算し，実測データのある核種について実测値と 比較し計算の有效性を確認した上で, 奏測が難しい核種に ついて計算で電離効果を求めている(3)。

工藤らは，捕獲 $\gamma$ 線に対する GM 計数管の検出効率を EGS4で計算している(4)。電離箱の場合は, EGS4でガス 中の吸収ェネルギーを求めることにより結果が得られる が, GM計数菅の場合には，検出器中での吸収エネルギー

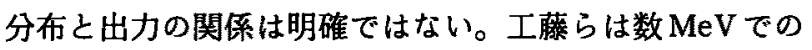
奏測值に合うようにディスクリレベルを設定し，このレべ ル以上のエネルギー吸収が発生した場合に計数するとして いる。この例のように, シミュレーションコードで得られ る物理量と実際の出力の間には様々な不確定の要因が関係 していることが多い。工藤らは, 高エネルギーの笚色 $\gamma$ 線 を発生させ GM計数营の効率を実験的に求める試みを始め ており ${ }^{(5)}$, 結果が得られるならば, 計算上の問題や課題が 明確になることが期待されている。

\section{(3) 反応別の $\gamma$ 線檢出器の応答計算}

$\gamma$ 線は検出器中で様々な反応を通じて 2 次電子を発生 し, この電子(あるいは陽電子)がシンチレーション等の出 力となる現象を起こす。 Nal(T1)シンチレータでは，検出 器中での吸収エネルギーが出力に比例するとしているが， 入射 $r$ 線のエネルギーがすべて検出器中で吸収された場合 に相当する「光電ピーク」について考えてす,

(a) 入射光子が検出器中で直接光電吸収を起こす

(b) 1 回コンプトン散乱を経過した後に, 光電吸収を起 こす

(c) 多数回コンプトン散乱を経過した後に, 光電吸取を 起こす

(d) 電子対生成を経由した後に, 検出器中ですべてのエ ネルギーを失う

場合が考えられる。测定ではこれらの反応ごとの心答を得 ることはできないが, シミュレーション計算では可能であ る。第 VII-1 図にペンシルビーム状の $3 \mathrm{MeV} \gamma$ 線が $3 \times 3$ in. $\mathrm{NaI}(\mathrm{Tl})$ シンチレータの中心に入射した場合の各反応ごと 

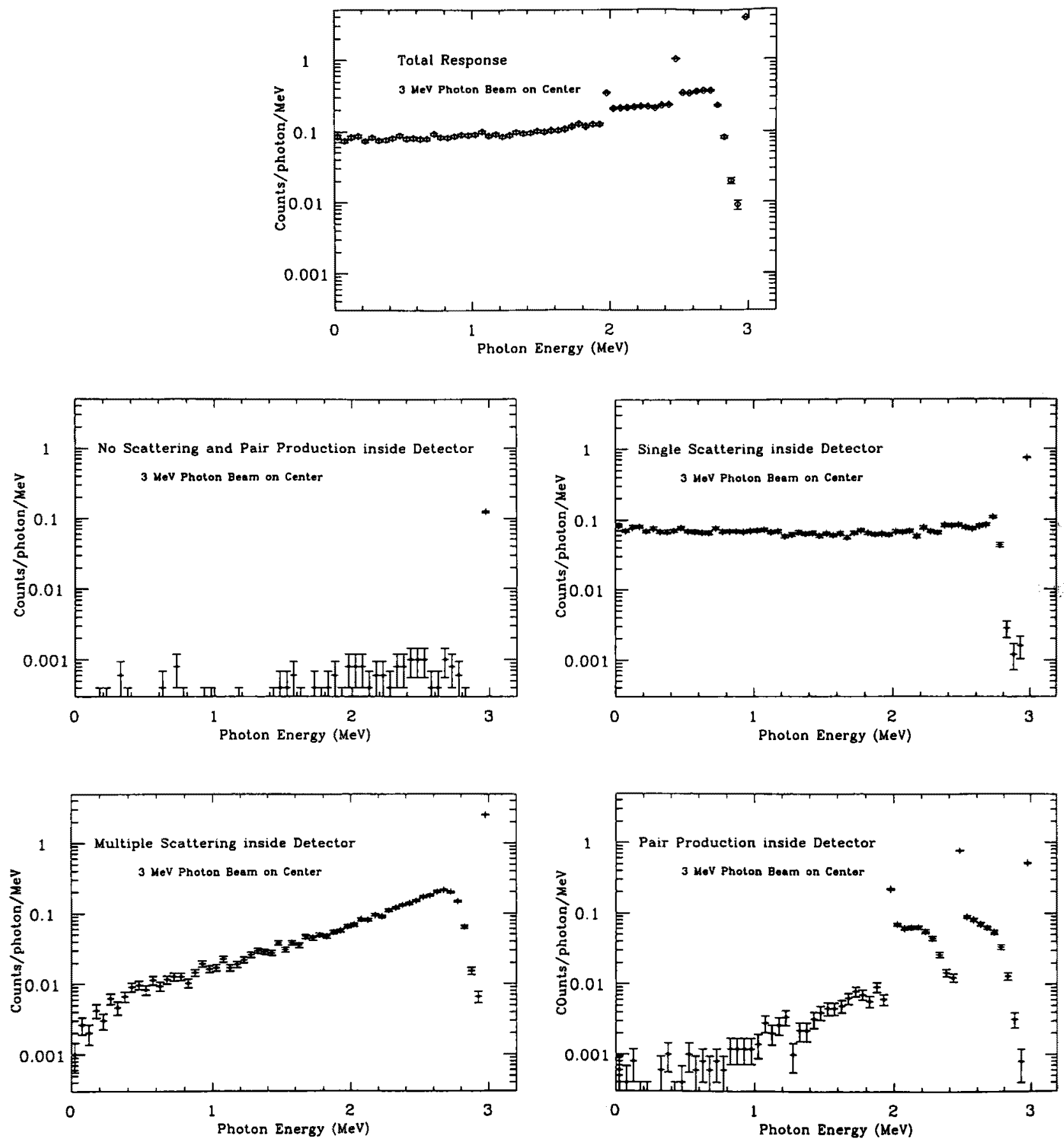

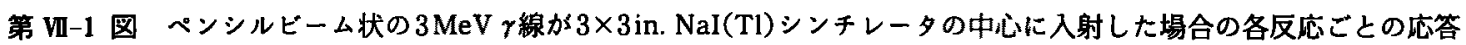

の応答を示す。この例は具体的な応用とは直接関係ない が，様々な要因による事象を測定している場合に，この例 のようにシミュレーション計算で個々の要因による寄与を 知ることにより検出器や容器, あるいは吸収体の設計など に有用な情報を得ることができるのではないかと思われ る。

(4) その他

検出器そのものに関係することではないが, 実際の計湘 においては，バックグラウンドを減らす工夫や，放射線を コリメートしてビーム状の線源を作ることが必要となるこ
とが多い。試行錯誤をするのも一つのやり方ではあるが, シミュレーションコードを用いて，最適の遮蔽やコリメー タの設計を行うことは実験を効率的に行う上でも重要なこ とである。

放射線測定器の研究者から具体的な要望(欲しい情報)が 出されればシミュレーションコードの利用範囲はもっと広 がるすのと思われる。EGS4については，毎年 7 月高エネ ルギー物理学研究所で「EGS4の使い方の講習」と「EGS4を 使用した研究交流」を目的とした「EGS4 研究会」を開催し ている。このような場を利用することにより,シミュレー 
ションコードを有用な道具として活用する放射線計測分野 の研究者が増えることは, シミュレーションコードの開発 に隽わっている者としてあうれしいことである。またよ り広い分野の利用の中から、シミュレーションコードの改 良課題が出てくることも期待している。

（平山英夫）

\section{2. ニューラルネットワークの放射線計測 への応用}

ニューラルネットワーク(以下NN)の放射線計湘への応 用は，主として欧米の素粒子実験で様々の型のものが用い られてきていることをまず指摘しておきたい。しかし本節 では最近，日本の原子力分野で研究されている階層型 NN に限る。NNの分類, 構造, 原理一般については最新の成書 を参照されたい(6)。階層型 NNは，脳神経細胞シナプスに 相当する素子(情報処理単位)が多数層状に結合されている もので，対象データを下層の入力層で受け取り，中間層な どで並列分散処理して上層に送り処理結果を出力するタイ ブのNNである(フィードフォワード型)。NN は本来，専 用ハードゥェアが理想であるが，多くの場合，通常の計算 機上で模擬プログラムとして利用されている。階層型 NN の機能は多次元入出力ベクトル変換器である。入出力量と しては実数， 2 值数などを要素とし，処理方式で線型素子 による線形型とシグモイド関数型素子による非線形型, 構 造では 2 層型とそれ以上の多層型(通常は 3 層)に分類され る。放射線計測分野です他と同様に非線形 3 層型が主であ るが，線形連想型も用いられている。

階層型 NN は初めから所望の性能を示すことはなく， 個々の素子中に記憶される，いわゆる重み係数の全体(以 下W)を教師付き学習過程で獲得する必要がある。教師付 き学習とは正しい入出力パターンの組みを用意し, 未学習 のNNに絽り返し入力し，その出力と正解出力: 教師情報 との差がなくなるようにWの值を少しずつ修正していく 過程である。学習には比較的長い時間を要する。なお，階 層型NN情報処理では，入カデータについては通常のパ ターン情報処理と同様に正規化の, 学習では過学習や収束 判定などの実用上直面する問題があるがここでは省略す る。

階層型NNの特徴は以下の 3 つにまとめられる ${ }^{(7)} 。$

(1) 非線形 NNの場合, 離散的な入出力関係を学習する だけで非線形性の強い写像機構を容易に構築可能 （適用性の簡便性）

（2）学習パターンを滑らかに内插し，末学習の入力に対 しても妥当な值を出力する(汎化能力)

(3) いったん学習が終了すれば，皘和演算を行うだけで 高速に出力が得られる(他用時の迅速性)

（1）線形連想型NNによるスペクトル解析

2 層線形連想型 NN はパターン認識機能を実現する(入 カパターン $x$ から連想されるパターン $y$ を $y=W x な る$ 行 列演算で出力)最も単純な NNである。連想のキーとなる
基本パターン間に 1 次独立性を仮定する。 $W$ を基本パ ターンを並ベた行列のムーア・ペンローズ一般逆行列にと れば最小自乗の意味で正しくパターンが想起される。W は教師付き学習であるWidrow-Hoff 学習則 ${ }^{(6)}$ や他の数学 的アルゴリズムで得られる。

この NNは $y$ 線や $x$ 線スペクトルの解析問題に適用され た。その前提は対象スペクトルが有限個の既知成分の重ね 合わせで構成されることである。NNの連想出力は成分ご との基本スヘククルに対する相対強度のパターンとなる。 基本スペクトルが絶対值付けられていれば直接的に絶対強 度分布が得られる。

$\gamma$ 線で $\mathrm{NaI}(\mathrm{T} 1)$ 検出器による一般の $\gamma$ 線スペクトル解 析 ${ }^{(8)}$ や原子力施設の環境 $\gamma$ 線監視への適用性が調べられ た ${ }^{(9)}$ 。後者の場合, 通常はいわゆる自然放射線が主体であ り，その成分す既知である。基本スペクトル(核種ごとの $\gamma$ 線測定スベクトル)をシミュレーション計算で推定し適 用したところ良好な結果を得た。さらに異常時の異成分混 入監視には直交射影ネットワークと呼ばれる拡張 NN法が

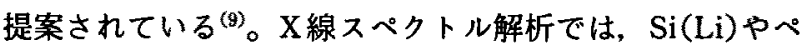
ルチエ効果冷却型X線検出器によるPIXEスペクトルを対 象に研究が進められている。 $\mathrm{Si}(\mathrm{Li})$ の場合元素ごとの基本 X線スペクトルを実験的に求める方法であ，モデル計算に よる方法でも，20個程度の元素を含む複雑なスペクトルを 高速で分析することに成功している(10)。

この方法の最大の特徴はスペクトルをパターンとして扱 い, 通常のピーク (群)の関数あてはめによる分離はしない ことである。したがって成分間で一部のピークに重畳が存 在してあ分離がほとんど完璧にできる。よって上記の例の ように検出器のエネルギー分解能が悪い場合でも，基本バ ターン間の独立性さえ高ければ適用できる。本手法は成分 の予測可能性が条件であるから，似たような多数の試料を 分析するような場合，特に産業的応用に好適である。

\section{(2) 非線形 NN の応用}

非線形NNの応用例は検出器波形情報処理である。放射 線検出器では一般に出力波形は, 多かれ少なかれ，反跳荷 電粒子の検出位置や飛行方向に依存し，これが波高欠損を 引き起こし，ひいては低分解能の原因となっている。この 波形情報を使うことができれば，反跳方向や位置の違いを 補正したり，大きく異なるあのを除去することにより分解 能を改善できる。そのような処理が最近の高速デジタル波 形計測装置により可能となってきた。非線形NNは他の方 法では, 得ることが困難な飛行方向や検出位置と波形の非 線形関係を誤差逆伝播学習法で容男に獲得する。

具体的には 3 層 NNを用いて CdTe検出器の分解能改善 に成功した例がある(11)。また NNではないがパターン マッチング法というほぼ同様の考え方による改善例もあ る(12)。一方, 波形情報の補正や弁別に止まらず，より積 極的に波形の違いを使う例むある。通常の長い比例計数管 の波形情報から険出位置情報を取り出す研究が行われてい 
る(13)。これによれば，比例計数管の芯線を抵抗性にする ことなく良好な位置検出器として使える。

別な纫用としては新しいアンフォールディング法の提案 がある(14)。つまり中性子ェネルギー感度の異なる多重放 射化簿の放射化率のデータから原子炬の中性子スペクトル を推定する問題である。スペクトル形状の異なった代表的 な原子吙スペクトルとその放射化パターンをNNに覮えこ ませ，別な原子炬のスペクトルを放射化データから推定さ せて良好な結果を得ている。

\section{(3) 今後の展望}

NN 応用は以上のような解析や変換問題に限らない。有 望なのは構造化学習による知識抽出である。構造化学習 は，分散化された素子や結合の中の弱いものを削ぎ落と し，同じ性能を示すなる心゙く単純な構造の NN 構築を目指 すむのである。石川は忘却付き学習之いう構造化学習法を 提案し，毒キノコの毒性と外見的特徵の関係のルールを導 くことに成功した ${ }^{(15)}$ 。この構造化学習を，例えば先の波 形デー夕好理に適用すると，単純かつ有効な波形処理方式 の発見につながる可能性がある。構造化学習の隠れた利点 は大きめな中間層素子数から出発できるので, 最適中間素 子数探索という問題に頭を悩ませる必要がなくなることで ある。

階層型 NNは，以上のように，放射線スペクトル解析や 波形解析で威力を発揮し始めている。しかし，NNの種類 とその能力からすれば，上記の適用例は対象のほんの一部 にすぎず，まだまだ未開拓領域が広がっている。今後の発 展を大いに期待したい。

（岩崎 信）

(1) Nelson, W. R., Hirayama, H., Rogers, D. W. O. : The EGS4 code system, SLAC-265, (1978).

(2) Rogers, D. W. O. : Nucl. Instrum. Methods, 199, 531 (1982).

(3) Torii, T., Nozaki, T., Ando, H. : Calculation of ionization efficiency of gas-flow type ionization chamber, Proc. $3 r d$ EGS4 Users' Meeting in Japan, KEK Proc. 93-15, p.58, (1993).

(4) Kudo, K., Takeda, N., Sakihara, K., Fukuda, A., Takahashi, $\mathrm{H}$. : Response of a GM counter to high energy photons calculated by the EGS4/PRESTA code, Proc. 5th EGS4 Users' Meeting in Japan, KEK Proc. 95-9, (1995).

（5）工藤勝久，他：原子力学会「1996春の年会」要旨集， G27，

(6) 例えば, へクトニールセン, R.：“ニューロコンピューティ ング",トッバン, 東京(1992).

(7) 矢川元基, 他：コンピュートロール, No.39, 26 (1992).

(8) Iwasaki, S., et al. : Intelli. Eng. Systems Through Artificial Neural Network, Vol.3, ASME Press, 199 (1993).

（9）福田,他：計測自動制御学会東北支部30周年記念学戒講演会 予稿集, p.101 (1994).

(10) Iwasaki, S., et al. : Internat. J. PIXE, 4 [2 \& 3], 131 (1994).

(11) Sakai, H., et al. : J. Radioanal. Nucl. Chem. Articles, 205, 147 (1996);

Takenaka, Y., et al. : Nucl. Instrum. Methods, A369, 637 (1996).

(12)福田大治, 他：原子力学会「1995秋の大会」予稿集, C16.

(13) 酒井宏隆, 他：同「1996春の年会」要旨集, G38.

(14) 井口哲夫, 他：放射線, 21 [3], 2 (1995).

(15) Ishikawa, M. : ANNES '95, 6 (1995).

\section{VII. おわりに}

\section{日本原子力研究所 片 桐 政 樹}

本年(1996年)がベクレルの放射線発見からちょうど100 年目に当たることから，将来の放射線センシングがどのよ うに発展してゆくのか，現状を踏まえて予測できるような 記事となれば幸いと考えて特集記事を企画した。取り上げ るべきテーマが非常に多くページ数が限られるため, 内容 をコンパクトにまとめていただくのに筆者の方々に大変ご 苦労をおかけしてしまったと思っている。また，今回の特 集記事に載せることのできなかった重要なテーマも少なか らず残っており，関係の方々には深くお詫びを申し上げ
る。

本記事内容は，この一世紀の間，目に見えない放射線を いかに検出するかという課題に対して，数々の研究者がア イデアを出し実験し新しい検出器を開発し，そしてその性 能を高めてきた歴史の到達した成果であると共に，今後の 放射線センシングの道しるべとなるるのと考えている。

将来の放射線センシングには，冒頭の章で述べられてい るように, 人間の眼と同様の機能を備えることが久かせな くなる。この開発目標に向けて一層の積極的な研究がなさ れることを期待するとともに，放射線をミク口量子世界の 探查などに応用する新しい研究分野の開拓が進むことを 願って本「特集」を閉じることにする。 